\title{
EDUCAÇÃO AMBIENTAL E MANEJO DE RECURSOS NATURAIS EM ÁREA DE PROTEÇÃO AMBIENTAL: O CASO DOS EXTRATORES DE SAMAMBAIAS DA ILHA COMPRIDA - SÃO PAULO
}

\section{VIVIAN GLADYS DE OLIVEIRA}

Dissertação apresentada à Escola Superior de Agricultura "Luiz de Queiroz", Universidade de São Paulo, para obtenção do título de Mestre em Recursos Florestais, com opção em: Conservação de Ecossistemas Florestais.

\author{
PIR A C I C A B A \\ Estado de São Paulo - Brasil \\ Março - 2002
}




\title{
EDUCAÇÃO AMBIENTAL E MANEJO DE RECURSOS NATURAIS EM ÁREA DE PROTEÇÃO AMBIENTAL: O CASO DOS EXTRATORES DE SAMAMBAIAS DA ILHA COMPRIDA - SÃO PAULO
}

\section{VIVIAN GLADYS DE OLIVEIRA}

Bióloga

Orientador: Prof. Dr. DALCIO CARON

Dissertação apresentada à Escola Superior de Agricultura "Luiz de Queiroz", Universidade de São Paulo, para obtenção do título de Mestre

em Recursos Florestais, com opção em: Conservação de Ecossistemas Florestais.

\author{
PIR A C ICABA \\ Estado de São Paulo - Brasil \\ Março - 2002
}


Dados Internacionais de Catalogaçăo na Publicaçăo (CIP) DIVISĀO DE BIBLIOTECA E DOCUMENTAÇĀO - ESALQ/USP

Oliveira, Vhian Gladys de

Educaçăo ambiental e manejo de recursos naturais em área de proteça ambiental : o caso dos extratores de samambaias da liha Comprida - \$5o Paulo / Vhlan Gladys de Oliveira. - - Piracicaba, 2002.

104 p. : il.

Dissertaç\o (mestrado) - . Escola Superior de Agricultura Lulz de Queiroz, 2002. Bibliografia.

1. Ecologia florestal2. Legislaç̧̃o ambiental 3. Proteç\$o ambiental 4. Recursos naturais 5 . Samambala L. Titulo

CDD 634.94

"Permitida a cópia total ou parcial deste documento, desde que citada a fonte - $\mathbf{O}$ autor" 


\section{AGRADECIMENTOS}

Ao meu pai Nestor, à minha mãe Laís que sempre com muito amor, carinho e dedicação foram os grandes incentivadores de minha aprendizagem;

Ao Marcelo, companheiro para todas as horas, sempre com muito amor, compreensão, dedicação e paciência esteve ao meu lado em todos os momentos desta trajetória.

Ao Marcos Sorrentino pelas valiosas contribuições, por sua dedicação intensa e pela amizade, além do constante compromisso com o meu aprendizado;

À Lúcia Ferreira pela confiança, oportunidade e amizade, incentivando meu crescimento acadêmico e contribuindo na realização deste trabalho;

Ao Professor Caron pela oportunidade, dedicação e disposição de ajuda no decorrer desses dois anos;

À amiga Maria Rita que sempre com muito afeto e generosidade em todas as etapas desta pesquisa, me ensinou que é possível ter coerência entre teoria e prática demonstrando-me o que é ser uma educadora de verdade;

Às integrantes do grupo de Educação Ambiental: Maria Rita, Alessandra, Alik, Érica, Caroline e Rita pelas valiosas trocas e incentivos ao longo dos últimos três anos, contribuindo para o meu crescimento intelectual e pessoal e principalmente agradeço pelos cafunés; 
Às amigas e companheiras de mestrado Maria Henriqueta e Lílian Patrícia, pelas intensas trocas, compartilhando as dores e as delícias;

Às amigas Ana Paula e Milena pelas acolhidas afetuosas e estimulantes ao longo do mestrado;

À Kellen e ao Chico pelas trocas e pela amizade;

À Raquel Macul pela ajuda com o inglês;

À Simone Sivieiro pela ajuda constante nos empréstimo de bibliografias e apoio logístico;

Às extratoras D. Joana, D. Benedita, Dilza, D. Helena, Cândida pelas inúmeras contribuições para a pesquisa de campo e pelos laços estabelecidos

Aos funcionários da Prefeitura Municipal de llha Comprida: Décio Ventura, Darci Ventura, Jô e Heitor pelo acesso facilitado à informações necessárias para a realização desta pesquisa.

Aos funcionários do Nepam: Neusa, Vanderlei e Nestor pelo apoio logístico;

Aos amigos Oscar Motta e Cristiane Ronza pela amizade e pelos primeiros incentivos à minha vida acadêmica;

Aos funcionários do Departamento de Recursos Florestais: Margareth e Alexandre pela paciência e ajuda;

Enfim, aos outros amigos Mylene, Déia, Lili, Zezinho, Vivi, Analú, Claudinha, Rodrigo, Norton, Jú, Lilia pelo carinho e os momentos felizes que temos desfrutados juntos, tornando essa empreitada muito mais agradável. 


\section{SUMÁRIO}

Página

LISTA DE SIGLAS .................................................................. vii

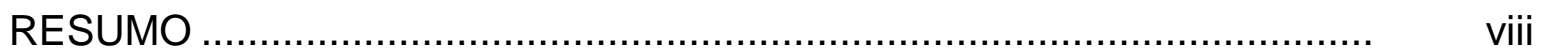

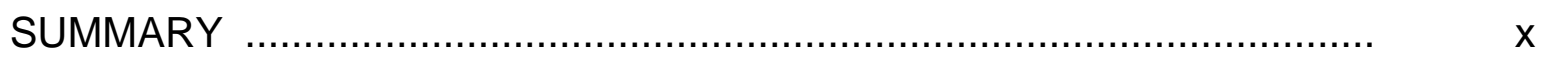

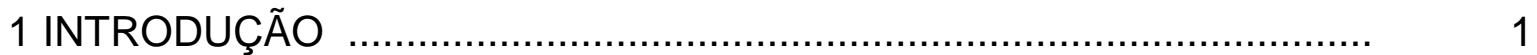

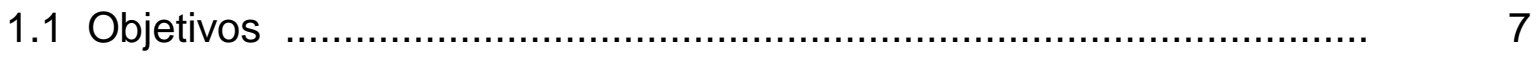

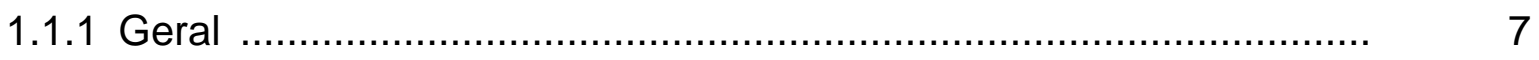

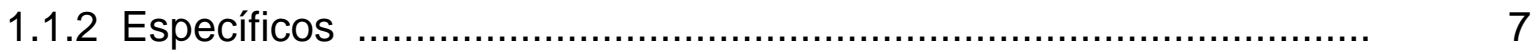

1.2 O Vale do Ribeira ................................................................... 8

1.3 Unidades de Conservação no Brasil .............................................. 11

1.3.1 As categorias de Unidades de Conservação implantadas no Brasil... 14

1.3.2 Conceito de APA ................................................................. 15

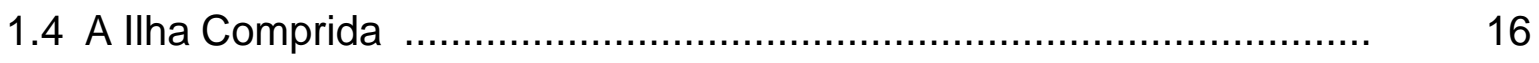

1.4.1 A Proposta da APA de Ilha Comprida ….................................... 20

1.4.1.1 A APA Estadual ................................................................ 20

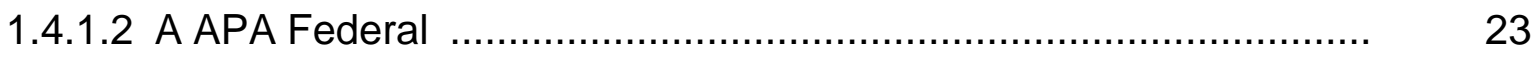

1.5 A população da llha Comprida ..................................................... 25

2 REFERENCIAL TEÓRICO ........................................................ 27

$2.1 \mathrm{Em}$ busca de tendências da Educação Ambiental .............................. 27

2.2 Os pressupostos de Educação Ambiental desta pesquisa ................. 30

2.3 Sobre participação.................................................................... 37

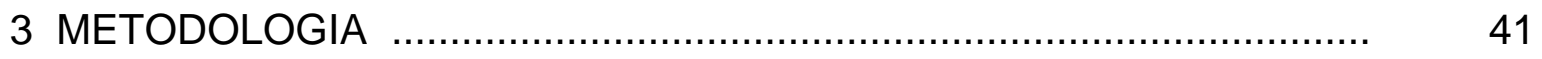


3.1 Sobre o componente Intervenções e Educação Ambiental ............... 42

3.2 Referenciais Metodológicos …...................................................... 45

3.2.1 Pesquisa Qualitativa ................................................................ 45

3.2.1.1 Sobre a pesquisa-intervenção educacional ............................... 49

3.2.2 Planejamento incremental articulado ....................................... 50

3.3 A coleta e análise de dados .......................................................... 51

3.3.1 Observação participante ........................................................ 52

3.3.2 Análise documental ........................................................... 53

3.3.3 Entrevistas ....................................................................... 53

3.4 A chegada na llha Comprida ………………........................... 54

3.4.1 Chegando em Pedrinhas ...................................................... 57

3.4.2 O cotidiano da extração ……………….................................. 58

3.5 Proposta de Intervenção …......................................................... 61

4 RESULTADOS E CONCLUSÕES ……………............................... 63

4.1 Sobre a prática extrativista ………………................................ 64

4.1.1 A extração antes da regulamentação da APAIC................................ 64

4.1.2 A atividade extrativista após a regulamentação da APAIC.................. 66

4.2 Sobre o plano de manejo ..................................................................... 69

4.3 Sobre a formação da AMPIC......................................................... 71

4.3.1 Sobre os extratores associados.................................................

4.4 Como funciona a extração, o escoamento e a comercialização............. 74

4.4.1 Das idas para o mato ..................................................................... $\quad 75$

4.4.2 Escoamento e comercialização........................................................ 77

4.5 Das reuniões................................................................................ 80

4.6 Identificando conflitos................................................................... 82

4.7 Como está funcionando hoje............................................................. 84

5 CONSIDERAÇÕES FINAIS ……............................................... 86

5.1 Etapas da Intervenção................................................................ 92

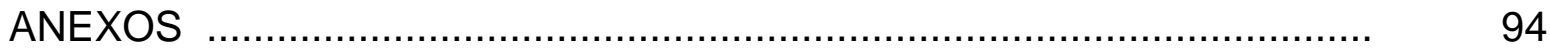

REFERÊNCIAS BIBLIOGRÁFICAS ................................................... 98 


\section{LISTA DE SIGLAS}

AMPIC - Associação de Manejadores de plantas nativas de llha Comprida APA - Área de Proteção Ambiental

APA/CIP - Área de Proteção Ambiental/ Cananéia, Iguape, Peruíbe APAIC - Área de Proteção Ambiental de Ilha Comprida

CONAMA - Conselho Nacional de Meio Ambiente

EA - Educação Ambiental

FAPESP - Fundação de Amparo à Pesquisa do estado de São Paulo

FAO - Organização para Alimentação e Agricultura

FBCN - Fundação Brasileira para Conservação da Natureza

IUCN - União Internacional para Conservação da Natureza

NEPAM - Núcleo de Estudos e Pesquisas Ambientais

ONGs - Organizações não Governamentais

PNUMA - Programa das Nações Unidas para o Meio Ambiente

SNUC - Sistema Nacional de Unidades de Conservação

SUDELPA - Superintendência para o Desenvolvimento do Litoral Paulista

UCs - Unidades de Conservação

UFSC - Universidade federal de Santa Catarina

UNESCO - Organização das Nações Unidas para Educação, Ciência e Cultura

UIPA - União Internacional de Proteção Ambiental

WWF - Fundo Mundial para Natureza 


\title{
EDUCAÇÃO AMBIENTAL E MANEJO DE RECURSOS NATURAIS EM ÁREA DE PROTEÇÃO AMBIENTAL: O CASO DOS EXTRATORES DE SAMAMBAIAS DE ILHA COMPRIDA SÃO PAULO
}

\author{
Autora: VIVIAN GLADYS DE OLIVEIRA \\ Orientador: PROF. DR. DÁLCIO CARON
}

\section{RESUMO}

Esta pesquisa visa contribuir para a produção de conhecimentos no campo da Educação Ambiental através da descrição do processo de formação da Associação de Extratores de Plantas Nativas da llha Comprida (AMPIC) e do estabelecimento de parceria desta associação junto à Prefeitura deste município, como partes do processo de institucionalização do Manejo Participativo de Samambaias Silvestres (Ruhmora adiantisformis) em Área de Proteção Ambiental. Seu foco está na análise da "participação" como dimensão essencial para que processos educacionais contribuam para a efetiva conservação do meio ambiente e melhoria da qualidade de vida. Além disso, pretende apresentar a organização comunitária em torno da extração da samambaia e contribuir na discussão sobre práticas educativas relacionadas à temática ambiental e sem esgotar as possibilidades auxiliar no direcionamento de tais iniciativas, destacando pontos importantes de reflexão para quem já atua ou pretende atuar em projetos com enfoque participativo. Para tanto, foram. 
utilizados como referenciais metodológicos a pesquisa qualitativa, a pesquisaintervenção. 


\title{
ENVIRONMENTAL EDUCATION AND MANAGEMENT OF NATURAL RESOURCES IN ENVIRONMENTAL PROTECTION AREAS: CASE-STUDY OF THE FERN EXTRACTORS IN ILHA COMPRIDA - SÃO PAULO
}

\author{
Author: VIVIAN GLADYS DE OLIVEIRA \\ Adviser: PROF. DR. DÁLCIO CARON
}

\section{SUMMARY}

This research aims at adding to the knowledge in the field of environmental education by describing the creation process of the AMPIC Native Plants of Ilha Comprida Extractors Association, and the establishment of a partnership between this association and the local government as part of the institutionalization process of the participative management of wild fern (Ruhmora adiantisformis) in environmental protection area. Its main focus is the analysis of "participation" as a core issue in obtaining educational processes that effectively contribute to enhancing the quality of life, as well as the environmental conservation. Moreover, it presents the community organization around the extraction of wild fern therefore allowing the discussion about educational strategies concerning the environmental theme. It also highlights important aspects to be considered by those who are already working or intend to work in projects with a participative approach, with a view to orienting such 
initiatives without covering all the possibilities, though. Qualitative and intervention researches were used as methodological reference in this 


\section{INTRODUÇÃO}

Esta pesquisa visa contribuir para a produção de conhecimentos no campo da Educação Ambiental através da descrição do processo de formação da Associação de Extratores de Plantas Nativas da llha Comprida (AMPIC) e do estabelecimento de parceria desta associação junto à Prefeitura deste município, como partes do processo de institucionalização do Manejo Participativo de Samambaias Silvestres ${ }^{1}$ em Área de Proteção Ambiental (APA). Seu foco está na análise da "participação" como dimensão essencial para que processos educacionais contribuam para a efetiva conservação do meio ambiente e melhoria da qualidade de vida.

O trabalho está vinculado ao projeto temático "Floresta \& Mar: Usos e Conflitos no Vale do Ribeira e Litoral Sul de São Paulo", desenvolvido no Núcleo de Estudos e Pesquisas Ambientais da UNICAMP. ${ }^{2}$

O Projeto Floresta \& Mar abrange o Vale do Ribeira e Litoral Sul de São Paulo, dando ênfase específica as Unidades de Conservação (UCs) e entorno: APA Federal Cananéia-Iguape-Peruíbe (APA/CIP), Parque Estadual Turístico do Alto do Ribeira (PETAR) e Estação Ecológica Juréia-Itatins. Seu principal objetivo é analisar a relação entre uso de recursos naturais, conflitos locais e regionais e forma de intervenção relacionadas à conservação e manejo de recursos naturais, a fim de compreender os aspectos fundamentais da implantação das UCs em território brasileiro (Ferreira \& Begossi, 1997) ${ }^{3}$.

\footnotetext{
${ }^{1}$ O termo samambaias será utilizado referindo-se a espécie Rumoha adiantisformis comercializada para arranjos florais ${ }^{2}$ Coordenado pelas Profas. Dras.Lúcia da Costa Ferreira e Alpina Begossi.

${ }^{3}$ FERREIRA, L.C. \& BEGOSSI, A. (coord) Floresta e Mar: Usos e Conflitos no Vale do Ribeira e Litoral Sul, SP. NEPAM, Unicamp. Processo Fapesp 14514-1, 1997 (mimeo).
} 
Conta com três componentes que são: 1) Uso, Estratégias de Uso e Dieta 2) Conflitos Sociais em Unidades de Conservação e 3) Intervenções e Educação Ambiental.

A pesquisa junto a AMPIC insere-se no componente Intervenções e Educação Ambiental do projeto Floresta \& $\mathrm{Mar}^{4}$, formado por graduandas e pós-graduandas, que buscam, na associação entre pesquisa e intervenção educacional, contribuir com as discussões acerca da Educação Ambiental no Vale do Ribeira.

A Ilha Comprida localiza-se no litoral sul do Estado de São Paulo e integra o Complexo Estuarino Lagunar de Iguape - Cananéia - Paranaguá (Figuras 1 e 2), parte da baixada sedimentar do Vale do Ribeira. O Complexo Estuarino Lagunar de Iguape-Cananéia-Paranaguá é considerado um dos mais produtivos ecossistemas do Planeta (SMA, 1996; Soares et al, 2000).

"As formações de Domínio Atlântico (manguezais, restinga, lagunas e florestas de planície) presente na região são áreas que apresentam mobilidade e fragilidade física, alta produtividade e diversidade biológica. Entre as principais funções que esses sistemas desempenham estão o controle de inundações, a retenção de sedimentos, a capacidade de armazenamento e descarregamento de água, a retenção de elementos tóxicos e a retenção e distribuição de nutrientes. Além dos atributos citados, esses ecossistemas respondem, ainda, por dois terços da produção mundial pesqueira, demonstrando sua importância tanto do ponto de vista ambiental como sob o aspecto econômico-social." (São Paulo, 1996).

\footnotetext{
${ }^{4}$ Equipe do componente Intervenções e Educação Ambiental - Coordenadora - Profa. Ms. Maria Rita Avanzi (FEUSPdoutoranda), Alessandra Buonavoglia Costa-Pinto (PROCAM-USP, mestranda), Rita de Cássia Nonato (IG/UNICAMP, iniciação científica), Vivian Gladys de Oliveira (ESALQ/USP, mestranda), Caroline Oliveira (FE/UNICAMP,TCC), Érica Speglich (FE/UNICAMP, mestranda), Alik Wunder (FE/UNICAMP, mestranda).
} 


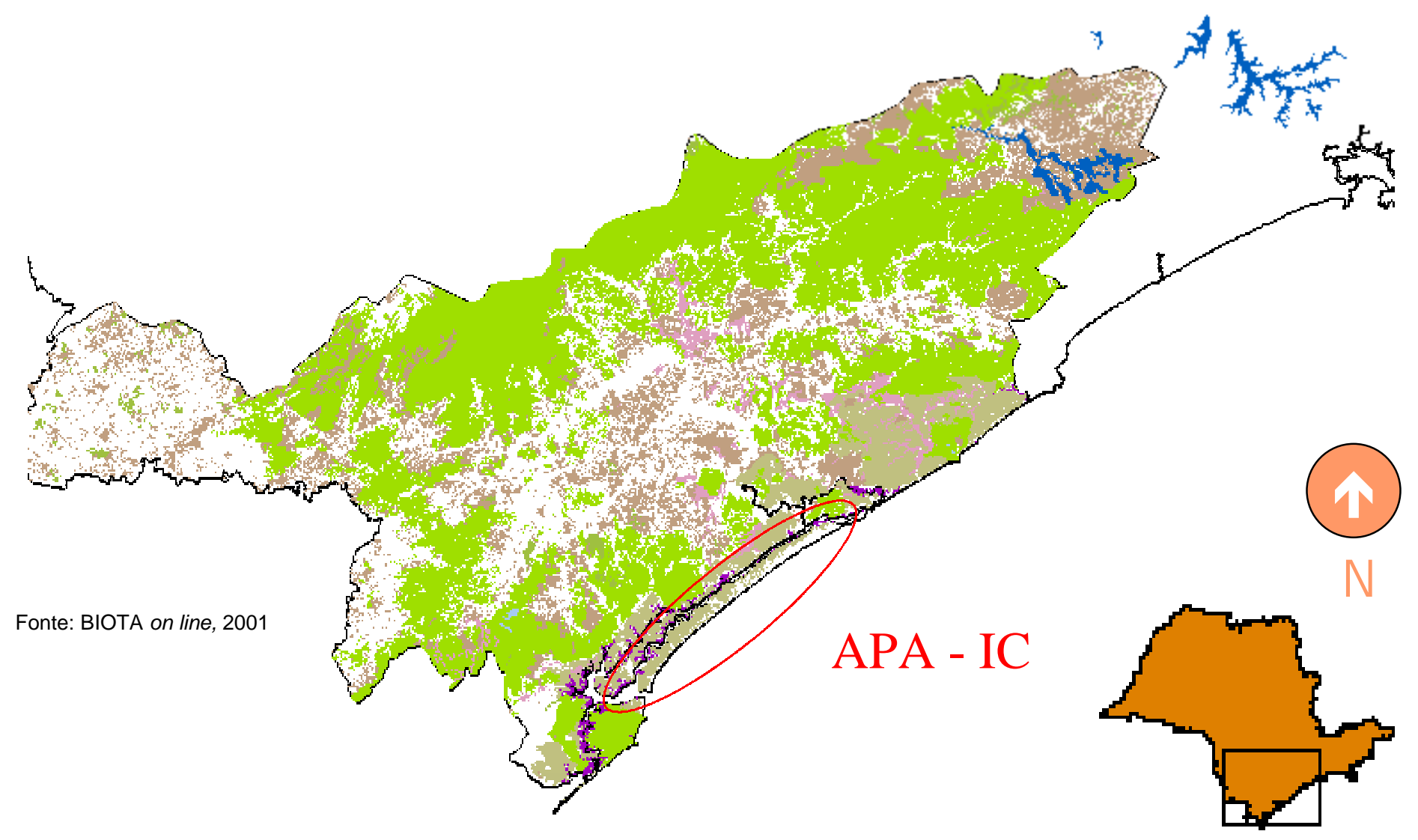

Figura 1 - Localização da APA de llha Comprida. 
O Vale do Ribeira e Litoral Sul do Estado de São Paulo compreendem grande parte das áreas de conservação da Mata Atlântica no país. Esta conservação é fruto da marginalização econômica pela qual passou a região ao longo do século XX. E é nesta região que estão os mais baixos índices de desenvolvimento e menor grau de urbanização do Estado de São Paulo, onde a maior parte da população desenvolve atividades agrícolas ou extrativistas (Hogan et al, 1999).

$\mathrm{Na}$ região existem áreas que estão sob proteção legal na forma de diversas categorias de UCs, que diferem entre si de acordo com o grau de restrição do uso dos recursos naturais e ocupação humana, entre as quais se incluem APA, Estação Ecológica e Parque Estadual. Dentre as UCs implantadas no Vale do Ribeira, o interesse desta pesquisa centra-se na llha Comprida que foi decretada APA em 1987.

Os critérios utilizados na criação destas UCs estiveram apoiados no conhecimento empírico-racional, em que se levaram em consideração principalmente os pareceres técnicos. Assim os grupos sociais locais e seus conhecimentos estiveram excluídos dos processos de criação destas UCs. (Diegues, 1997).

De acordo com Ferreira $(2001)^{5}$ as UCs propostas no Brasil

“(...) foram resultado de um processo arbitrário de tomada de decisões, cujos atores partiam da suposição de que a conservação de remanescentes florestais não seria um direito reivindicado pelas coletividades que vivem e moram nos limites territoriais de suas esferas de atuação" (Ferreira et al, 2001:3).

\footnotetext{
${ }^{5}$ Ferreira, L. C. et al. Conflitos sociais em áreas protegidas no Brasil: moradores, instituições e ONGs no Vale do Ribeira e Litoral Sul de São Paulo - trabalho apresentado Congresso de Sociologia - Fortaleza 2001.
} 
A legislação é restritiva no que diz respeito à ocupação humana e ao uso de recursos naturais destas áreas, o que significa muitas vezes enfraquecer direitos sociais e políticos adquiridos pelos grupos residentes no interior e entorno destas UCs. Isto acaba por remeter a uma discussão que vem sendo imposta ao ambientalismo brasileiro desde seus primórdios e que atuou como contraponto a sua inserção na sociedade brasileira: a tensão entre conservação ambiental e bem estar social (Ferreira, 1996; Costa-Pinto et al 2001).

Em escala local no Vale do Ribeira, logo após a Rio $92^{7}$, houve um período com experiências de intensa convivência entre instituições e moradores das UCs implantadas. Dá-se início, nesse período, a uma mobilização dos agentes institucionais como o poder público, organizações não governamentais (Ongs), organizações comunitárias, em busca de soluções para os conflitos e demandas locais, e para isso, a palavra de ordem era "participação", sem que houvesse uma decodificação aprofundada do termo (Ferreira et al, 2001).

Algumas iniciativas locais, tomando como base o Decreto $750^{8}$, foram criadas buscando resolver ou minimizar a situação de suspensão de direitos e de geração de renda à qual estava sendo submetida a população residente em áreas protegidas do estado de São Paulo (Ferreira et al, 2001).

Dentre as iniciativas observadas como alternativa de geração de renda e de legalização de práticas extrativistas na Ilha Comprida, esta pesquisa visa sistematizar informações sobre como se deu a institucionalização do manejo participativo de samambaias, a organização comunitária em torno da criação da AMPIC e a sua parceria com a Prefeitura Municipal da llha Comprida. A análise dessas informações sistematizadas busca levantar elementos que possam identificar processos educacionais emancipatórios relacionados à formação e funcionamento da AMPIC.

${ }^{6}$ COSTA-PINTO, A.; WUNDER, A.; OLIVEIRA, C.; SPEGLICH, E.; JUNQUEIRA, K.; AVANZI, M. R.; NONATO, R.C.; SAMPAIO, S. M. V.; OLIVEIRA, V. G. Partilhando saberes: reflexões sobre educação ambiental no Vale do Ribeira, SP. Encontro de Pesquisa em Educação Ambiental, UNESP - Rio Claro, 2001 (no prelo).

7 Conferência das Nações Unidas sobre Meio Ambiente e Desenvolvimento, que aconteceu no Rio de Janeiro em junho/1992.

${ }^{8}$ Decreto 750 - de 10/02/1993 - Dispõe sobre o corte, a exploração e a supressão de vegetação primária ou nos estágios avançado e médio de regeneração de Mata Atlântica, e dá outras providências. 
Segundo Telles (1994) as organizações e movimentos populares são potencialmente transformadores da dinâmica da sociedade atual apesar dos desafios do "pesado legado da tradição autoritária e os dilemas postos pelas transformações em curso na sociedade e do mundo contemporâneo". A autora vê nos grupos populares organizados um potencial de construção de "espaços públicos". Espaços em que "as diferenças podem se expressar e se representar numa negociação possível", onde ocorre a circulação de valores, articulação de argumentos, formação de opinião, de permanente e sempre renovada interlocução, de convivência democrática com as diferenças e conflitos (Telles, 1994:92).

Entendendo a organização do grupo extrativista em torno da AMPIC e sua parceria junto à Prefeitura potencialmente como um "espaço público", em que se delineia a possibilidade de um enfrentamento participativo das questões ambientais, emergem algumas perguntas:

1) Em que medida a organização dos extratores em torno da AMPIC e de sua parceria com o poder público:

$\checkmark$ Pode contribuir para que os extratores se potencializem e se insiram na discussão da temática ambiental e na gestão de recursos naturais locais?

$\checkmark$ Pode ser deflagradora de processos educacionais que caminhem para a construção de uma cultura participativa?

2) Quais as contribuições da Educação Ambiental (EA) para fortalecer esse estabelecimento de "espaços públicos", ou seja, participação popular na gestão ambiental, inserção das comunidades na discussão da temática ambiental e, em última instância, de emancipação do sujeito político?

A seguir estarão sendo apresentados os objetivos geral e específicos desta pesquisa.

Nos itens 2 e 3 será apresentado um breve histórico da região do Vale do Ribeira e os critérios utilizados para o estabelecimento de UCs no Brasil, no 
item 4 será feita uma apresentação da llha Comprida (município onde ocorreu esta pesquisa) e a proposta da APA de llha Comprida (APAIC) e da APA de Cananéia-Iguape-Peruíbe (APACIP).

Cabe ressaltar que ao longo desta introdução serão utilizados conceitos que estarão sendo decodificados no decorrer deste capítulo, sendo que outros serão aprofundados no capítulo 2 que destina a apresentar o referencial teórico da pesquisa.

No capítulo 3 serão delineados os procedimentos metodológicos, ficando para os capítulos 4 e 5 a apresentação dos resultados, discussão e considerações finais.

\subsection{Objetivos}

\subsubsection{Geral}

$\checkmark$ Contribuir para a produção de conhecimentos relacionados a Educação Ambiental e Participação.

\subsubsection{Específicos}

$\checkmark$ Descrever e analisar o processo de organização dos extratores de samambaias em torno da AMPIC;

$\checkmark$ Sistematizar as informações sobre participação levantadas no processo de institucionalização do plano de Manejo Participativo de Samambaias Silvestres da Ilha Comprida/SP;

$\checkmark$ Identificar e analisar os fatores limitantes e potencializadores de processos educacionais emancipatórios em uma organização que realiza manejo coletivo de recursos naturais;

$\checkmark$ Contribuir para a compreensão de como se dá à relação dos associados com os parceiros e a relação deles entre si, procurando identificar conflitos; 


\subsection{O Vale do Ribeira}

O Vale do Ribeira localiza-se entre o Paraná e São Paulo, numa faixa que compreende desde municípios próximos à capital paulista até quase as cercanias de Curitiba (PR), e no litoral desde as proximidades de Peruíbe (SP), no ponto mais ao norte, até chegar em Paranaguá (PR), no ponto mais ao sul. O Vale do Ribeira comporta uma multiplicidade de tempos e espaços simultâneos, representações dos vários sujeitos que hoje vivem ou atuam lá (Carvalho, 1999).

Do ponto de vista social, é a região mais pobre do estado de São Paulo, contudo, apresenta grandes riquezas em recursos naturais. É lá que se localiza a maior parte que resta da Mata Atlântica no Estado, onde encontram-se diversas espécies animais em risco de extinção e uma beleza paisagística que abriga consideráveis recursos hídricos e minerais (Carvalho, 1999).

A população caiçara ${ }^{9}$ começou a formar-se nos primeiros anos de colonização com a chegada da esquadra de Américo Vespúcio em 1502, já o povoamento do interior começou um pouco mais tarde, pois para que se adentrasse a Terra firme era necessária uma licença especial do governador ou do provedor-mor da fazenda real (Moreira apud Carvalho, 1999; Diegues, 2001)..$^{10}$

No século XVII, às margens do rio Ribeira de Iguape no interior, foi encontrado ouro, formando um povoamento e originando então a primeira cidade do interior do Vale, Xiririca (atualmente Eldorado). Iniciou-se então o primeiro ciclo econômico da região, embora no litoral a principal atividade continuasse sendo a agricultura e a pesca de subsistência (Carvalho, 1999).

A atividade aurífera entrou em declínio no final do século XVII quando iniciou o ciclo do arroz, que perdurou até o início do século XX. O transporte da

\footnotetext{
${ }^{9}$ São chamadas caiçaras as comunidades formadas pela mistura étinica de índios, portugueses e negros. Seu modo de vida baseia-se na agricultura itinerante, na pesca, extrativismo e artesanato (Diegues, 2001)
} 
população e o escoamento da produção regional eram feitos, ao longo do rio Ribeira e seus afluentes, através de barcos e canoas até um ponto próximo ao porto da Ribeira, em Iguape, de onde a produção era transportada em mulas até o porto de Iguape.

Com o objetivo de eliminar o trajeto feito no lombo de mulas e tornar mais rápido o escoamento da produção local, no final do século XIX a solução mais prática foi a abertura de um canal ligando o rio ao mar, aproveitando a chamada "Vala do Rocio" que havia sido iniciada em $1805 .{ }^{11}$

A abertura do canal, atualmente chamado de Valo Grande, foi feita pelos escravos no período entre 1837 e 1855 e acabou transformando lguape em uma ilha.

Esse canal a princípio tinha apenas quatro metros de largura, contudo acabou sendo alargado pela força e volume das águas do rio, chegando aos 200 metros de largura, o que ocasionou o assoreamento das barras de Icapara e do Ribeira e, inclusive, do próprio porto de Iguape. A partir deste fato, o porto de Iguape entrou em franco declínio e a produção do arroz começou a sofrer concorrência do arroz de outras regiões, e no início do século $X X$ a produção de arroz no Vale do Ribeira já havia diminuído muito.

Nesse período, o acesso através de estradas quase inexistia, o que contribuiu para um isolamento geográfico, econômico e social da região. O Vale mergulhou num período de estagnação econômica que se estendeu pelas décadas de 1910, 20 e 30, e a maior parte da população voltou-se para a economia de subsistência, sobretudo para o consumo doméstico (Zan apud Carvalho, 1999).

$\mathrm{Na}$ década de 1920, o chá preto desenvolveu-se em níveis comerciais e na década de 1930 o cultivo de banana começa a tomar expressão na região, tornando-se mais tarde a base da economia local.

${ }^{10}$ Caiçaras: Território e cultura revisitados - texto apresentado no seminários interdisciplina NUPAUB 28/05 a $1 / 06 / 2001$

${ }^{11}$ Documento consultado na Prefeitura Muncipal de Ilha Comprida - S.P, s/d 
A intensificação do processo de incorporação do Vale à produção capitalista ocorreu nas décadas de 1940 e 50 com a ampliação do cultivo da banana e do chá. Esse processo foi acelerado na década de 1960 com a construção da rodovia BR-2, atual BR 116, que acabou gerando uma valorização de terras no Vale em função da deflagração de especulações fundiárias (Carvalho, 1999).

Devido às características físicas, montanhas e cavernas, grandes extensões de Mata Atlântica, o Vale foi escolhido como local de treinamento de guerrilheiros de Carlos Lamarca. Temendo que a região fosse alvo de novos focos guerrilheiros, o Estado começou a investir em projetos desenvolvimentistas no final da década de 1960 e na década de 1970. Diversos programas foram implantados no Vale, com o objetivo de desenvolver a região e livrá-la do "atraso" e isolamento: aumento da produtividade agrícola, o estabelecimento de empresas agropecuárias, indústrias de transformação da banana e outras frutas, mineração, implementação da pesca, cultivo de cacau e de seringueira. Porém, nenhum desses projetos conseguiu industrializar o Vale (Carvalho, 1999).

Em função do difícil acesso, pelas péssimas condições das poucas estradas, e por ter estado à margem do desenvolvimento econômico do Estado de São Paulo, a região permaneceu isolada, o que propiciou a manutenção de remanescentes da Mata Atlântica, bem como de grupos sociais detentores de culturas diferenciadas da cultura urbana (Diegues, 1999).

A região do Vale, por abrigar a maior parte dos remanescentes de Mata Atlântica no Estado de São Paulo, tem sido nas últimas décadas, objeto de criação de diversos tipos de UCs. A implantação dessas diversas modalidades de UCs ocorreu sem que houvesse a menor preocupação com as populações que ocupavam as áreas que estavam ganhando novo status (Diegues, 1994:11). 
Em grande parte dessas áreas protegidas, o cultivo das roças familiares e a extração de produtos da mata foram proibidos, o que em muitos casos gerou uma situação de clandestinidade. Isto ocorreu também com a extração de samambaias na llha Comprida.

\subsection{As Unidades de Conservação no Brasil}

O modelo de UCs adotado no Brasil, e no Terceiro Mundo, deriva do modelo norte-americano, construído no século XIX, com o objetivo de proteger a vida selvagem (wilderness) ameaçada pelo avanço da civilização urbanoindustrial (Arruda, 1999).

Nos EUA, o acentuado desenvolvimento urbano-industrial da segunda metade do século XIX fez despontar uma preocupação com os ecossistemas naturais que vinham sendo degradados pelo ser humano. Com o objetivo de ao menos garantir a preservação de amostras desses ecossistemas contra a ação antrópica, surge então o conceito de área natural protegida, denominada no Brasil de unidades de conservação.

Inicialmente, a implantação destas áreas ocorreu nos EUA com a criação, em 1872, do Parque Nacional de Yellowstone. No início, estas áreas de grande beleza cênica foram destinadas principalmente ao desfrute da população das cidades norte-americanas que, estressada pelo acelerado ritmo do capitalismo industrial, buscava encontrar no mundo selvagem a "salvação da humanidade", predominando assim uma visão estética da natureza, tendo os artistas e filósofos como seus maiores disseminadores (Diegues, 1999; Adams, 2000).

A idéia que alicerça este modelo vem de uma concepção de natureza "romântica" ou seja, de que a transformação e domesticação de toda a biosfera pelo ser humano é inevitável, sendo necessário e possível preservar fragmentos do mundo natural em seu estado originário, antes da intervenção humana. Locais onde o ser humano pudesse reverenciar a natureza intocada, 
recompor suas energias materiais e espirituais e pesquisar a própria natureza (Arruda, 1999).

A definição das áreas a serem colocadas sob proteção, suas modalidades incluindo a elaboração de seus planos de manejo, foram sempre pensadas exclusivamente pelo Estado (Arruda, 1999).

Desta forma, este modelo criou uma dicotomia conflitante entre o ser humano e a natureza, supondo que as comunidades locais são incapazes de desenvolver um manejo ou no mínimo de participar de sua elaboração, e de que estas áreas podem ser perpetuadas num estado de natural equilíbrio.

O modelo amplamente adotado nos EUA é dito "excludente", pois seus planos de manejo se desenvolveram com a intenção de isolar os interesses dos habitantes locais das UCs. Este modelo contrapõe-se ao "inclusivo", adotado mais freqüentemente na Europa Ocidental, em que os interesses das sociedades locais foram fundamentais para a implantação das UCs (UICN, 1997).

Considerando-se que o modelo excludente possa ser adequado aos EUA, sua transferência para países em desenvolvimento mostra-se problemática, devido a ocorrência de populações humanas nas áreas prioritárias para conservação (Arruda, 1999).

De acordo com Brito (1995), especificamente no que se refere a conservação da biodiversidade, é inegável os avanços alcançados com a criação de UCs no Brasil. Porém, também são inegáveis que os problemas ainda hoje apresentados são os mesmos dos primórdios de implantação destas UCs.

Portanto, guardadas as peculiaridades locais, o que tem ocorrido nos países em desenvolvimento, é um conjunto de conseqüências indesejáveis da aplicação deste modelo, tais como: 
“(...) agravamento das condições de vida destas populações; expulsão das populações locais para as periferias das cidades, engrossando as multidões em situação de miséria e a proliferação de favelas; desenvolvimento de práticas clandestinas de superexploração no interior da área protegida; crescimento do conflito rural, descumprimento da legislação" (Arruda, 1999).

Neste sentido, o reconhecimento dessas populações locais, na valorização de seu saber, na melhoria de suas condições de vida e na garantia de sua participação na construção de uma política de conservação da qual sintam-se parte e sejam também beneficiadas, possivelmente possa ser uma das únicas vias adequadas para alcançar os objetivos a que se propõe a criação das UCs. 


\subsubsection{As categorias de UCs implantadas no Brasil}

O poder público tem-se utilizado de várias estratégias na busca de soluções para a preservação ou conservação de determinados ecossistemas. A criação de UCs com diferentes graus de isolamento e extensão territorial, tem ocorrido, passando o seu controle para o poder público (Soares et al, 2000).

No Brasil, de acordo com a Lei no 9.985, de 18 de julho de 2000, que institui o Sistema Nacional de Unidades de Conservação (SNUC):

"Unidade de Conservação é um espaço territorial e seus recursos ambientais, incluindo as águas juridicionais, com características naturais releventes, legalmente instituído pelo Poder Público, com objetivos de conservação e limites bem definidos, sob regime especial de administração, ao qual se aplicam garantias adequadas de proteção". $^{12}$

As UCs no Brasil são dispostas em dois grupos dos quais derivam as demais categorias, são elas:

"Unidades de Proteção Integral cujo objetivo básico é preservar a natureza, sendo admitido apenas o uso indireto dos recursos naturais, com exceção dos casos previstos; e as Unidades de Uso Sustentável cujo objetivo é compatibilizar a conservação da natureza com o uso sustentável de parcela dos seus recursos naturais". ${ }^{13}$

\footnotetext{
${ }_{13}^{12}$ BRASIL. Lei no 9.985, de 18 de julho de 2000. Institui o Sistema nacional de Unidades de Conservação.

${ }^{13}$ Idem.
} 
Dentro das Unidades de Proteção Integral estão: Estação Ecológicas, Reservas Biológicas, Parques Nacionais, Monumentos Naturais e Refúgios de Vida Silvestre. As Unidades de Uso Sustentável contemplam: Áreas de Proteção Ambiental, Áreas de Relevante Interesse Ecológico, Florestas Nacionais, Reservas Extrativistas, Reservas de Fauna, Reservas de Desenvolvimento Sustentável e as Reservas Particulares do Patrimônio Natural.

O município de Ilha Comprida, onde se desenvolve esta pesquisa, insere-se na categoria "Unidades de Uso Sustentável", pois desde 1984 é considerada uma Área de Proteção Ambiental (APA).

\subsubsection{Conceito de APA}

Criada pela lei $n^{\circ} 6.902$, de 27 de abril de 1981, a APA, entre outras finalidades exerce o papel funcional de fixar zonas destinadas ao exercício das atividades humanas, respeitando as áreas de maior importância ecológica e consideradas de preservação permanente pelo Código Florestal (São Paulo, 1996).

Segundo a Resolução (Conselho Nacional de Meio Ambiente) CONAMA $\mathrm{n}^{\circ} 10 / 88$, artigo $1^{\circ}$, as APAs:

“(...) são unidades de conservação, destinadas a proteger e conservar a qualidade ambiental e os sistemas naturais ali existentes, visando a melhoria da qualidade de vida da população local e também objetivando a proteção dos ecossistemas regionais". ${ }^{14}$

${ }^{14}$ CONAMA, Conselho Nacional do Meio Ambiente, resolução $n^{\circ}$ 10/88, artigo 1, dispõe sobre Área de Proteção Ambiental. 
A Lei 9.985, que o SNUC, no artigo 15 define APA como sendo uma área:

“(...) em geral extensa, com um certo grau de ocupação humana, dotada de atributos abióticos, bióticos, estéticos ou culturais especialmente importantes para a qualidade de vida e o bem estar das populações humanas, e tem como objetivos básicos proteger a diversidade biológica, disciplinar o processo de ocupação e assegurar a sustentabilidade do uso dos recursos naturais." ${ }^{15}$

Portanto, trata-se de uma UC de uso direto, ou seja, aquela que pode ser implantada em área de domínio privado, pois convive com o exercício normal das atividades que decorrem do direito de propriedade, sujeitando-se, entretanto, a algumas restrições necessárias à proteção dos recursos naturais.

\subsection{A llha Comprida}

Localizada ao sul do litoral paulista, a llha Comprida faz parte do complexo estuarino lagunar de Iguape, Cananéia e Paranaguá, formado por um conjunto de ilhas, planícies, colinas, morros, serras e desembocadura de rios (Figura 2). Junto ao continente forma um sistema de lagunas, verdadeiros mares interiores de água salobra, densamente ocupadas por formação de manguezais (São Paulo, 1989).

\footnotetext{
${ }^{15}$ Brasil, 2000 op. cit.
} 


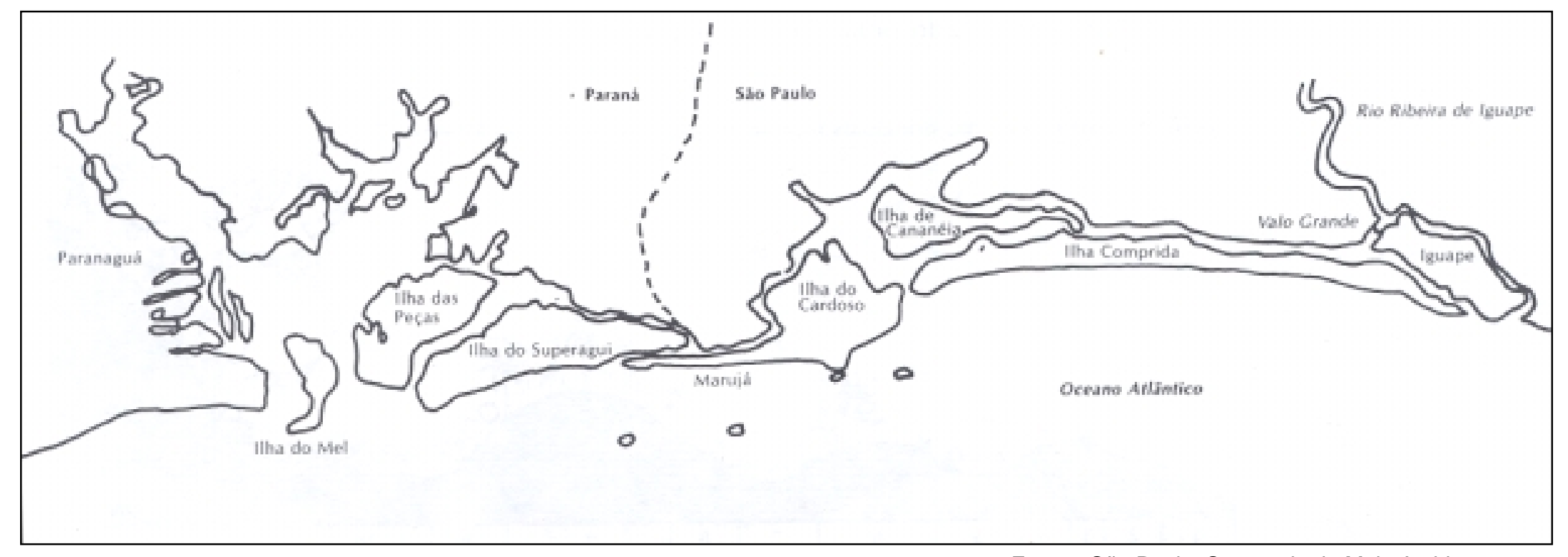

Fonte: São Paulo, Secretaria do Meio Ambiente, 1989.

Figura 2 - Região Estuarino-Lagunar de Iguape (SP) - Paranaguá (PR). 
A llha Comprida é formada pelo acúmulo de sedimentos marinhos e apresenta três partes distintas: a faixa litorânea com $74 \mathrm{Km}$ de praias e dunas; o interior com lagoas e rios de pequeno porte e vegetação de restinga; e a faixa voltada para o Mar Pequeno, um dos maiores criadouros de espécies marinhas do mundo.

A Ilha Comprida desempenha um papel importante na proteção a ambientes internos da formação lagunar, pois funciona como uma barreira natural da ação dos ventos e das ondas do mar (Soares et al, 2000).

O solo é arenoso de composição arenítica, apresentando lençol freático próximo à superfície, seu território é raso, alagadiço, composto de mangues, matas, vegetação rasteira, dunas e restingas. A vegetação de restinga é mais desenvolvida na beira dos rios e constitui importante zona de alimentação para a fauna da floresta adjacente e da própria llha. Sua topografia quase plana apresenta em alguns pontos elevações e lombadas como, por exemplo, o Morretinho, nas margens do Mar Pequeno na ponta sul da llha (Soares et al, 2000).

Apesar de apresentar precárias condições de ocupação, a llha Comprida foi quase completamente loteada sem qualquer planejamento local. Até 1992 a Ilha Comprida pertencia aos municípios de Iguape (dois terços a norte da llha) e Cananéia (um terço ao sul), quando então se emancipou.

Cabe salientar que o Município tem como principal atividade econômica o turismo. Calcula-se, que entre os meses de dezembro a fevereiro, passem pelo Município mais de 1.000 .000 de pessoas (PMIC, 1997).

Em 1984 foi decretada a APA federal de Cananéia-Iguape-Peruíbe (APACIP), cuja Ilha Comprida também estava incluída, e em 1987 foi decretada a APA Estadual de Ilha Comprida que abrange o município de llha Comprida e está sobreposta à APA/CIP. 
Na Ilha Comprida, assim como nos demais municípios do Vale do Ribeira, após o estabelecimento de uma categoria de UC, a população local, que utilizava os recursos naturais como forma de subsistência, foi impedida legalmente ou no mínimo temporariamente.

A extração de samambaias que tem especial destaque nesta dissertação foi proibida, o que colocou os extratores na condição de clandestinos. A legislação prevê a regulamentação de atividades extrativistas, desde que a comunidade extrativista esteja organizada na forma de associação e que se realize estudos que comprovem a sustentabilidade dos ecossistemas com a utilização de recursos naturais.

Diante da situação instaurada, a prefeitura local através de parceria com pesquisadores da Universidade Federal de Santa Catarina (UFSC) deu início em 1998 aos estudos biológicos da samambaia silvestre ao mesmo tempo que buscou organizar os extratores para formar uma associação. Em 1999 cria-se a AMPIC e estabelece-se o Manejo Participativo de Samambaias Silvestres. Como já foi dito anteriormente, as informações de todo este processo estarão sendo relatadas no capítulo 4.

\subsubsection{A proposta da APA de Ilha Comprida}

\subsubsection{A APA Estadual}

A APA estadual de llha Comprida (APAIC) foi promulgada por meio do Decreto $n^{\circ} 26.881$ de 11 de março de 1987 e regulamentada pelo Decreto $n^{\circ}$ 30.817 de 30 de novembro de 1989, resultado de um trabalho solicitado pela Prefeitura Municipal de Iguape à Superintendência do Desenvolvimento do Litoral Paulista ${ }^{16}$ (SUDELPA) quando a llha ainda pertencia aos municípios de Iguape e Cananéia (Soares et al, 2000).

\footnotetext{
${ }^{16}$ Pertencia à extinta Secretaria do Estado dos Negócios do interior.
} 
Pela proposta da APA-IC, dividiu-se a Ilha Comprida basicamente em cinco zonas (Figura 3), que trazem informações sobre restrições legais impostas e localização dos balneários ao longo da llha Comprida respectivamente. Segue abaixo a delimitação territorial de cada uma das zonas:

1) ZUs - Zonas Urbanizadas - subdividida em:

a) ZU 1 - cujos limites se estendem do Di Franco ao Araça, e do Mar de Fora até o Candapuí.

b) ZU 2 - cujos limites também se estendem do Di Franco ao Araça, e do Mar de Dentro (Mar Pequeno) até o Candapuí

c) ZU 3 - contempla basicamente o Bairro de Pedrinhas

d) ZU 4 - contempla o Boqueirão Sul

\section{2) ZOCs - Zona de Ocupação Controlada - subdividida em:}

a) ZOC 1 - (Norte) parte do Di Franco, até o Vila Nova, do Mar de Fora até o Candapuí

b) ZOC 2 - (Sul) parte do Boqueirão Sul para o Boqueirão Norte com aproximados $9.000 \mathrm{~m}$ também do Mar de Fora até o Candapuí.

\section{3) ZPE - Zona de Proteção Especial:}

Do Balneário Araça até a Ponta da Praia lado Norte, de Mar a Mar. 


\section{4) Nps - Núcleo de Pescadores:}

Núcleo de Vila Nova

Núcleo do Boqueirão Sul

Núcleo de Ubatuba

Núcleo de Trincheiras

Núcleo Sítio Artur

Núcleo de Juruvaúva

Núcleo do Morretinho

\section{5) ZVS - Zona de Vida Silvestre:}

Porção do território mais preservada.

O restante do território que não se encaixa nos demais zoneamentos 


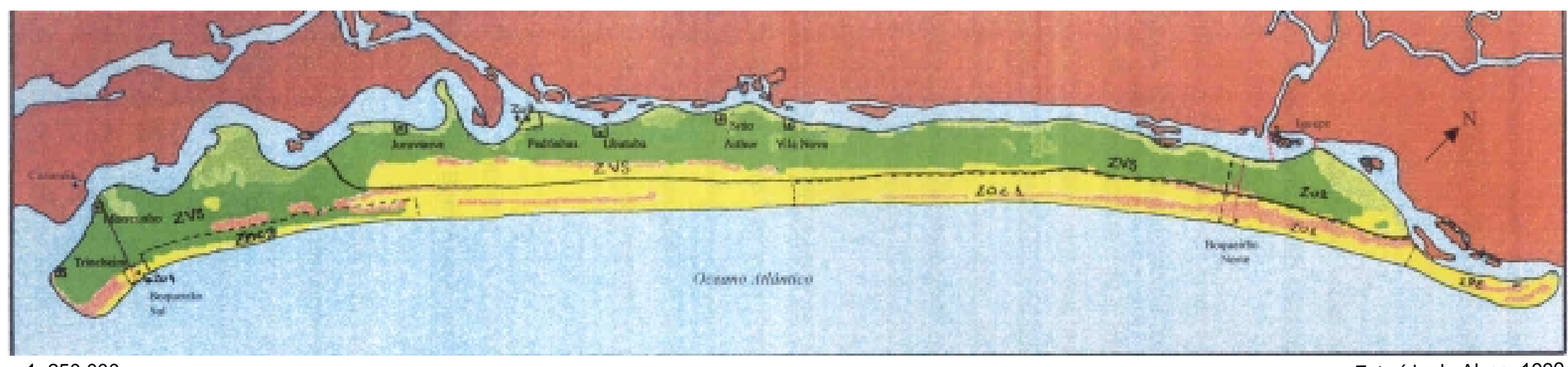

1: 250.000

Extraído de Alves, 1999

Figura 3 - APA de Ilha Comprida - Zoneamento Ambiental estabelecido pelo decreto no 30.817/89.

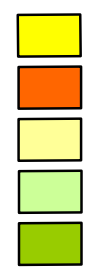

Dunas

Entre Dunas

Restinga

Mangues

Formação Ilha

Comprida

Floresta Pluvial -

Planície Litorânea

Recursos Hídricos

— Principais vias

---- Trecho de travessia de balsa

- Ponte Iguape-Illha Comprida

- Área de depósito de resíduos sólidos

---- Limite do zoneamento da APA
ZVS - Zona de Vida Silvestre

ZOC - Zona de Ocupação especial

ZPE - Zona de Proteção especial

ZU - Zona Urbanizada

- Núcleo de pescadores

- Principais centros

\begin{tabular}{|c|c|}
\hline Zona & Restrições apontadas pelo decreto $30817 / 89$ \\
\hline Zona de Vida Silvestre & \multirow{3}{*}{ Não serão permitidos parcelamentos de solo, qualquer que seja a modalidade } \\
\hline Zona de Proteção Especial & \\
\hline Núcleo de pescadores & \\
\hline Zona de Ocupação Especial & \multirow{2}{*}{$\begin{array}{l}\checkmark \quad \begin{array}{l}\text { Lotes mínimos serão de } 1000 \mathrm{~m}^{2} \text {, quando projetada a dotação de sistema coletivo de } \\
\text { tratamento completo de esgoto; }\end{array} \\
\checkmark \quad 2000 \mathrm{~m}^{2} \text { quando adotado sistema individual de tratamento e disposição de esgotos; } \\
\checkmark \quad \text { Poderá ainda ser exigido lote de até } 3500 \mathrm{~m}^{2} \text { em função da capacidade de sustentação do } \\
\text { solo e do sistema de tratamento e disposição final do esgoto a ser adotado. }\end{array}$} \\
\hline ZOC 1 e 2 & \\
\hline Zona Urbanizada & \multirow[b]{2}{*}{$\checkmark \quad$ Lotes mínimos serão de $500 \mathrm{~m}^{2}$} \\
\hline ZU $1,3,4$ & \\
\hline ZU 2 & $\begin{array}{l}\checkmark \quad \text { Lotes mínimos de } 1000 \mathrm{~m}^{2} \text {, desde que exista rede de abastecimento de água e coleta de } \\
\text { esgotos, com sistema de tratamento }\end{array}$ \\
\hline
\end{tabular}




\subsubsection{A APA Federal}

Em 23 de outubro de 1984 através do Decreto Federal 90.347 foi implantada a APA/CIP e pelo decreto Federal 91.892 de 6 de novembro de 1985 outras áreas foram acrescidas.

A APA/CIP, através do seu zoneamento ecológico econômico, prevê VII Unidades de Gestão (Figura 4).

Dentro dessa proposta, a llha Comprida ficou inserida em duas Unidades de Gestão:

I - Alta proteção através do controle e manejo sustentado;

IV - Conservação através do gerenciamento e controle, com medidas de recuperação.

Em linhas gerais, para a unidade de Gestão I, os objetivos específicos seriam:

$\checkmark$ Mapear as comunidades tradicionais;

$\checkmark$ Apoiar o sistema tradicional de complementariedade econômica objetivando sua modernização;

$\checkmark$ Preservar a fauna em extinção;

$\checkmark$ Implementar projetos - piloto de manejo sustentado;

$\checkmark$ Mobilizar a comunidade em ações de Educação Ambiental;

$\checkmark$ Conservar os ecossistemas com ênfase nas áreas núcleos;

$\checkmark$ Incentivar e apoiar a pesca artesanal;

$\checkmark$ Regulamentar o extrativismo comunitário;

$\checkmark$ Promover o ecoturismo;

$\checkmark$ Implementar a formação de agentes de saúde. 


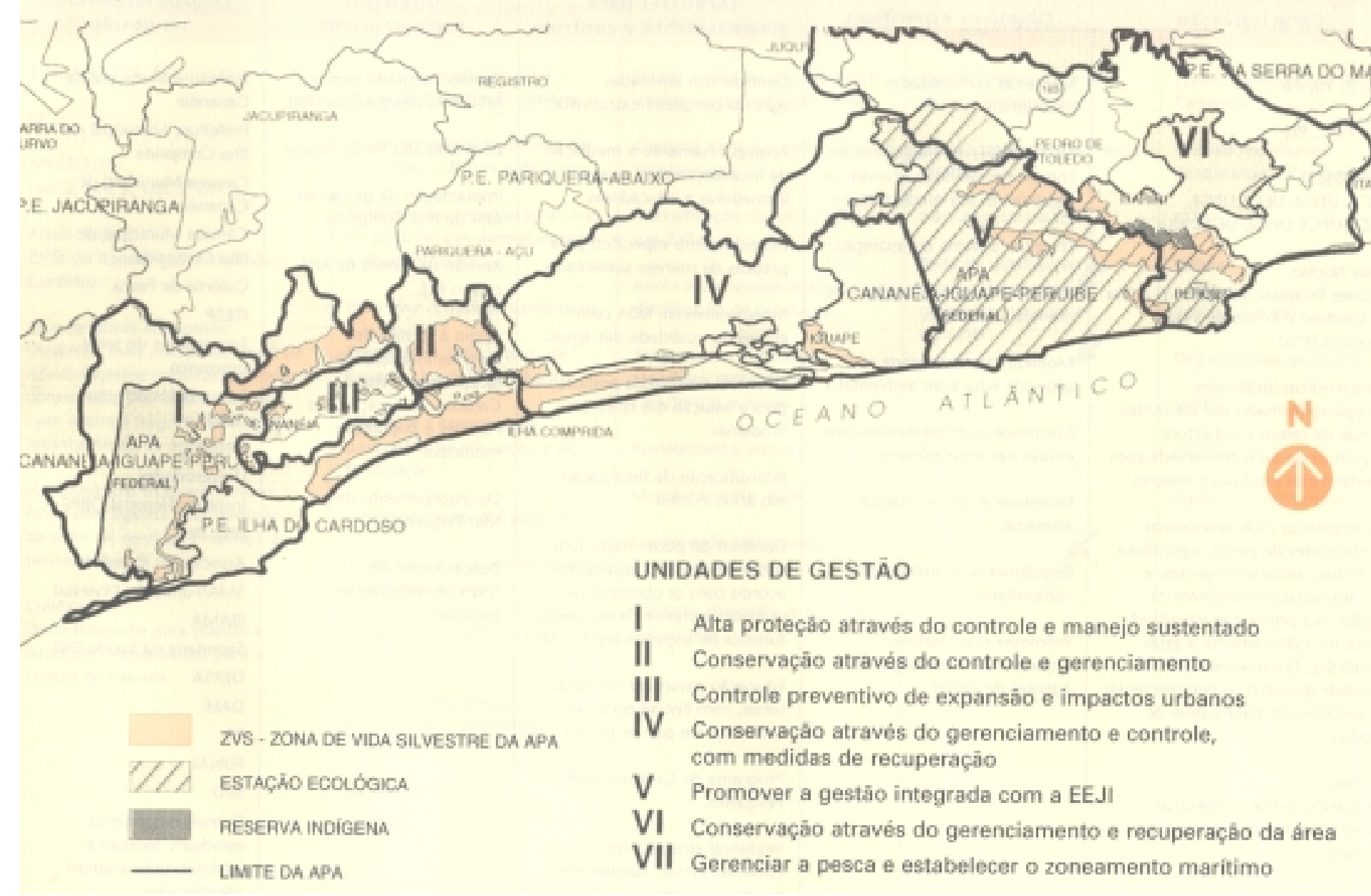

Figura 4 - Unidades de Gestão da APA/CIP.

Fonte: São Paulo, Secretaria do Meio Ambiente, 1996. 
Para a unidade de Gestão IV, em linhas gerais os objetivos específicos seriam:

$\checkmark$ Promover o extrativismo, o turismo, a pesca e a agricultura;

$\checkmark$ Conservar os recursos naturais de modo sustentado: subsistência, comercialização, turismo;

$\checkmark$ Evitar a emigração da população rural, provendo-a de meios de subsistência, atendimento médico, odontológico e escolas;

$\checkmark$ Estabelecer a ocupação adequada na Ilha Comprida;

$\checkmark$ Equacionar a questão do Valo Grande;

$\checkmark$ Restabelecer a produtividade pesqueira;

$\checkmark$ Proteger a fauna ameaçada, com programas de educação;

$\checkmark$ Garantir saneamento eficiente: esgotos e resíduos sólidos;

$\checkmark$ Promover agenda cultural e de lazer.

\subsection{A população da Ilha Comprida}

A população de Ilha Comprida foi estimada pelo IBGE, segundo dados de 1991, em 3.434 habitantes. A prefeitura municipal contesta esse número, estimando, através do censo escolar, do número de prontuários no Serviço Municipal de Saúde, e no registro do Cartório Eleitoral, que essa população ultrapasse certamente os 8.000 habitantes. Toda a população é considerada urbana, pois pela Lei Orgânica do Município, em Ilha Comprida não existe Zona Rural (Soares et al, 2000).

De acordo com Carvalho (1999), dentre os bairros que compõem o município de Ilha Comprida sete são caiçaras: Vila Nova, Pedrinhas, Sítio Arthur, Ubatuba, Juruvaúva, Morretinho, e Trincheira. 
A coleta de dados desta pesquisa se concentrou no bairro de Pedrinhas, onde se concentra cerca de $60 \%$ das famílias caiçaras da llha. A escolha deste bairro será explicada no capítulo 3. 


\section{REFERENCIAL TEÓRICO}

Neste capítulo será apresentado o referencial teórico que embasou esta pesquisa. Parte-se de uma breve exposição das principais correntes que constituem o movimento ambientalista e os fazeres educacionais chamados de EA. Buscou-se também clarear os pressupostos de EA que fundamentaram o trabalho e decodificar as dimensões do conceito de participação que deram suporte na análise dos resultados. Cabe ressaltar que as reflexões sobre EA são fruto de construção coletiva ocorrida dentro do grupo de $E A^{1}$, ao longo dos três últimos anos e meio de trabalho no Vale do Ribeira (1999-2002).

\subsection{Em busca de tendências da Educação Ambiental}

De acordo com Sorrentino (1998) assim como o movimento ambientalista, as diversas "educações ambientais" podem ser classificadas em quatro grandes correntes: "conservacionista"; "educação ao ar livre"; "gestão ambiental" e "economia ecológica".

A primeira corrente, muito presente nos países desenvolvidos, ganha estímulo a partir do livro "Primavera Silenciosa" (Carlson, 1962), que desencadeia reflexões de muitos ambientalistas sobre as causa e conseqüências da degradação ambiental. No Brasil, sua penetração ocorre a partir da atuação de entidades conservacionistas (UIPA e FBCN, dentre outras) e da primeira tradução para o português de um livro (Tanner, 1978) sobre educação Ambiental (Sorrentino, 1998).

\footnotetext{
${ }^{1}$ A dinâmica da trajetória do grupo está descrita no capítulo 3.
} 
A segunda está mais ligada a modalidades de esporte e lazer junto à natureza, e somente recentemente ganha a dimensão de EA com grupos de "caminhadas ecológicas", "trilhas de interpretação da natureza", "turismo ecológico" e outros. Nos países do Norte, tem mais consistência filosófica e um grande número de adeptos.

A terceira corrente tem raiz nos movimentos sociais da América Latina e no Brasil ganhou impulso especial no período militar, nos movimentos contra a poluição das empresas, nas conseqüências de um sistema predador do ambiente e do ser humano e nos movimentos por liberdades democráticas que possibilitassem a participação popular na administração dos espaços públicos.

A quarta e última corrente, bebe na fonte do "ecodesenvolvimento" e ganha impulso dos organismos internacionais na segunda metade da década de 1980 a partir da elaboração de documentos como "Nosso futuro comum" (Comissão Brundtland, 1987), "Nossa própria agenda" (1989) e a "Estratégia mundial para conservação"/ "Cuidando do Planeta Terra" (IUCN/PNUMA/WWF, 1980 e 1991) e com diretrizes dos bancos mundiais da FAO, UNESCO e outros órgãos internacionais. De acordo com Sorrentino (1998) nesta quarta corrente estão presentes duas vertentes que deram a tônica do movimento ambientalista no final do século $X X$.

“(...) 'desenvolvimento sustentável' e 'sociedades sustentáveis'. A primeira aglutinando empresários, governantes e uma parcela das organizações não governamentais e a segunda aglutinando aqueles que sempre estiveram na oposição ao atual modelo de desenvolvimento e que acreditam que a primeira corrente é só uma roupagem para a manutenção do 'status quo"' (Sorrentino, 1998, p.275).

De acordo com Sorrentino (1998), as diferentes correntes que constituem o movimento ambientalista, bem como aquelas citas de EA, possibilitam identificar os projetos de EA que se propõe em diversos locais do país. 
São eles:

"biológicos : Proteger, conservar e preservar espécies, ecossistemas e o planeta como um todo; conservar a biodiversidade e o clima (deter buraco na camada de ozônio e o efeito-estufa); detectar as causa da degradação da natureza, incluindo a espécie humana como parte da natureza; estabelecer as bases corretas para a conservação e utilização dos recursos naturais;

espirituais/culturais : Promover o auto-conhecimento e o conhecimento do Universo, através do resgate de valores, sentimentos e tradições e da reconstrução de referências espaciais e temporais que possibilitem uma nova ética fundamentada em valores como verdade, amor, paz, integridade, diversidade cultural, felicidade e sabedoria, visão global e holística;

políticos : Desenvolver uma cultura de procedimentos democráticos; estimular a cidadania e a participação popular; estimular a formação e aprimoramento de organizações, o diálogo na diversidade e a auto-gestão política;

econômicos: Contribuir para a melhoria da qualidade de vida através da geração de empregos e renda em atividades "ambientais", não alienantes e não exploradoras do próximo. Caminhar em direção à auto-gestão do seu trabalho, dos seus recursos e dos seus conhecimentos, como indivíduos e como grupos/comunidades“ (Sorrentino, 1998, p. 276-277).

$\mathrm{Na}$ perspectiva do autor, estes quatro conjuntos de temas/objetivos poderiam ser reduzidos em um grande objetivo geral:

"Contribuir para a conservação da biodiversidade, para a auto-realização individual e comunitária e para a auto-gestão política e econômica, através de processos educativos que promovam a melhoria do meio ambiente e da qualidade de vida" (Sorrentino, 1998, p.277). 


\subsection{Os pressupostos de Educação Ambiental desta pesquisa}

Diante do que foi apresentado anteriormente, nota-se que são muitas as concepções de educação que se auto-denomimam de EA. Avanzi (1998) destacou algumas questões que buscam caminhos para entender o que nos fala a EA:

“(...) de trabalhos destinados à preservação de determinada área natural? De uma pedagogia não humanista? Da formação de sujeitos que se coresponsabilizem, ao lado do poder público, pelo zelo de seu ambiente imediato e de outros espaços que lhes fogem do olhar cotidiano? De valores humanos identificados com os pressupostos da cooperação e respeito à vida em diferentes raças, condições sócio-econômicas, hábitos culturais e gerações? Da busca de qualidade de vida, respeitando as diferenças sociais existentes entre países ricos e pobres? De uma metodologia de estudo do meio e de seus problemas associados? De um novo movimento que visa a modificação da relação entre sociedade e natureza?" (Avanzi, 1998, p.6).

Sem desconsiderar as diferentes leituras suscitadas pelo termo, nesta dissertação parte-se do pressuposto de que a EA está imbuída de um conteúdo político e de que a ação educativa situa-se numa ampla e complexa relação de conflitos histórica, social e culturalmente condicionados. Desta forma, compreendendo que para haver a internalização deste pressuposto à prática, seja necessário trabalhar sob a perspectiva da "pedagogia da demanda" (Gutiérrez \& Prado, 1999, p.50).

A "pedagogia da demanda" dá ênfase aos interlocutores enquanto protagonistas, busca em primeira instância "(...) a satisfação das necessidades não satisfeitas, desencadeando em conseqüência, um processo gestor de 
iniciativas, propostas e soluções." O processo pedagógico essencial é o vivencial, intuitivo, dinâmico, complexo e experencial.

Segundo estes autores, a educação centrada na demanda, exige uma pedagogia da intercomunicação a partir da cotidianidade dos interlocutores. Nessa pedagogia, o sentido do processo nasce do acontecer dinâmico, dos problemas percebidos na cotidianidade e da busca de solução (Gutiérrez \& Prado, 1999, p. 50).

No entanto, dentro do campo da EA tem sido presente também uma visão que se baseia em proposições e práticas coercitivas, verticais, enunciativas. Esta associação da EA a práticas de coerção - em que a noção de estabelecimento de direitos por parte das coletividades, tão cara à cidadania (Benevides, 1991; Jelin, 1994), é substituída pela noção de cumprimento de deveres - tende a polarizar a discussão entre conservação ambiental e bem estar social (Costa-Pinto et al, 2001). As ações de EA pautadas nesta visão buscam enquadrar as práticas sócio-culturais locais nos princípios da conservação ambiental, colocando-os muitas vezes como algo imposto de cima para baixo, desconsiderando peculiaridades locais.

A concepção de EA que dá sustento a este projeto busca pensar a construção do conhecimento sobre a temática ambiental como um diálogo que se estabelece entre diferentes formas de interpretar a realidade.

Dialogando com Freire (1975), pode-se buscar elementos para compreender 0 ato do conhecimento:

“(...) Conhecer não é o ato através do qual um sujeito transformado em objeto, recebe dócil e passivamente os conteúdos que outro the dá ou the impõe. O conhecimento pelo contrário, exige uma presença curiosa do sujeito em face do mundo. Requer sua ação transformadora sobre a realidade. Demanda uma busca constante. Implica invenção e reinvenção (...)O sujeito enchido por conteúdos cuja inteligência não percebe; conteúdos que contradizem a forma própria de estar em seu mundo sem 
que seja desafiado não apreende. Dar-se conta deles não é conhecê-los." (...) a ação educadora deve ser a de comunicação se quiser chegar ao homem, não ao ser abstrato, mas ao ser concreto inserido numa realidade histórica".

Assim, as práticas de EA coercitivas podem ser compreendidas como uma imposição de uma cultura (a do educador ambiental) sobre outra (a do educando) sendo esta imposição cultural também uma imposição epistemológica, na maioria das vezes legitimada pelo conhecimento empírico-racional, visto como a única forma válida de conhecimento. Considera-se portanto, que tal postura resulta em um empobrecimento do horizonte e das possibilidades do conhecimento.

Refletindo sobre a história da ciência e considerando a imposição epistemológica do conhecimento do norte do planeta em relação ao sul, Souza (1999) usou oportunamente a expressão "epistemicídio", comparando-a ao genocídio provocado pela expansão européia:

"O genocídio que pontuou tantas vezes a expansão européia foi também um espistemicídio: eliminaram-se povos estranhos porque tinham formas de conhecimento estranhas e eliminaram-se formas de conhecimento estranho porque eram sustentadas por práticas sociais e povos estranhos. (...) Se hoje se instala um sentimento de bloqueamento pela ausência de alternativas globais ao modo como a sociedade está organizada, é porque durante séculos, sobretudo depois que a modernidade se reduziu à modernidade capitalista, se procedeu a liquidação sistemática das alternativas quando elas, tanto no plano epistemológico, como no plano prático, não se compatibilizaram com as práticas hegemônicas" (1999, p.328, 329)

Em contrapartida a esta concepção, que invalida os conhecimentos não científicos, existem outras que aceitam como verdadeira a tese de que há muitas 
formas válidas de conhecimento, de onde seguem como decorrência, atitudes que venham valorizar os conhecimentos e práticas não hegemônicas. Isto implica a escuta de práticas marginais, desvelando-se rastros de utopias silenciadas, para fundamentar a busca de soluções aos problemas da sociedade contemporânea (Santos, 1989).

Se um dos princípios da EA, estabelecido no item 10 do "Tratado de Educação Ambiental para Sociedades Sustentáveis e Responsabilidade Global”2, é o exercício da cidadania, pode-se perguntar a que cidadania estas práticas de cima para baixo se referem?

"A educação ambiental deve estimular e potencializar o poder das diversas populações, promover oportunidades para as mudanças democráticas de base que estimulem os setores populares da sociedade. Isto implica que as comunidades devem retomar a condução de seus próprios destinos."

Do ponto de vista da educação para a cidadania ativa, "(...) aquela que institui ao cidadão como portador de direitos e deveres, mas essencialmente criador de direitos para abrir novos espaços de participação política" (Benevides, 1999 , p.9) entende-se que posturas coercitivas acabam por reforçar muito mais o conceito passivo e tutelar de cidadania, na medida em que desconsidera o sujeito individual, ator de sua vida pessoal e coletiva, para referir-se a um cumpridor de papéis que Ihes são atribuídos (Benevides, 1994).

Pode-se repensar esta função de papéis, visando construir com Alain Touraine o conceito de sujeitos social:

\footnotetext{
${ }^{2}$ Documento finalizado e aprovado durante a Ria/92 pelo Fórum Internacional de ONGs e Movimentos Sociais.
} 
"Por que o ator não é aquele que age em conformidade com o lugar que ocupa na organização social, mas aquele que modifica 0 ambiente material e sobretudo o social no qual está colocado, modificando as relações de trabalho, as formas de decisão, as relações de dominação ou as orientações culturais" (Touraine, 1997, p. 220-21).

E ainda lembrando Marilena Chauí(1984) citada por Benevides (1999):

(...) a cidadania se define pelos princípios da democracia, significando necessariamente conquista e consolidação social e política. A cidadania exige instituições, mediações e comportamentos próprios, constituindo-se na criação de espaços sociais de lutas e na definição de instituições permanentes para a expressão política"

Mas como construir este conceito de cidadania ativa? Ou, segundo reflexões de Demo (2000, p. 164), como passar da cidadania assistida à cidadania ativa?

"A cidadania assistida já é cidadania, porque se funda no direito inalienável de sobrevivência, um direito certamente radical. $O$ ideal da sociedade e da pessoa, todavia, não é ser assistido. Deparamo-nos aqui com uma das dialéticas mais duras da realidade social: ninguém se emancipa sem a ajuda dos outros, mas o processo de emancipação implica dispensar ajuda."

Portanto, nos diferentes projetos de pesquisa do grupo de EA, bem como em suas atuações educativas, visualiza-se uma consonância com o objetivo enunciado por Sorrentino: "contribuir para a conservação da biodiversidade, para a auto-realização individual e comunitária e para a auto-gestão política e econômica, através de processos educativos que promovam a melhoria do meio ambiente e da qualidade de vida" (Sorrentino, 1998, p. 193). 
Este objetivo para a EA se aproxima daqueles da educação popular comunitária, fundamentada no reconhecimento da diversidade cultural, no desenvolvimento da autonomia de pessoas, grupos e instituições e na promoção da cidadania. Seu motor é a melhoria da qualidade de vida, partindo do princípio que os processos educativos ocorrem na medida em que se participa ativamente dos processos sociais e sobre eles se reflete coletivamente. A educação popular compreende o momento de reflexão comunitária sobre a própria prática como o ponto culminante e desencadeador do processo educativo (Gutiérrez Perez, 1994).

Buscando-se uma aproximação entre o princípio da autonomia política da educação popular e aqueles princípios da EA apontados por Sorrentino (1998), é possível visualizar alguns fios que nortearam tanto o desenvolvimento desta pesquisa quanto as ações do grupo EA no Vale do Ribeira.

Desta forma, partindo da realidade encontrada no Vale do Ribeira, considera-se que uma EA que problematiza a relação entre conservação ambiental e bem estar social, partindo do desenvolvimento de capacidades e competências locais para o enfrentamento dos problemas, possa trazer importantes contribuições para a realidade conflituosa da região (Costa-Pinto et al, 2001).

Seguindo este raciocínio, as pesquisas e intervenções desenvolvidas pelo grupo de EA no Vale do Ribeira, partem de dois pressupostos: a) de que diferentes espaços sociais são potencialmente educativos e produtores de conhecimento, b) de que a relação horizontal entre os saberes em processos educativos constitui-se, potencialmente, em exercício de participação política.

Segue abaixo algumas discussões teóricas ligadas a estes dois pressupostos.

A educação, partindo da dimensão apontada por Dayrell (1996, p.142), ocorre nos mais diferentes espaços e situações sociais, num complexo de experiências, relações e atividades, cujos limites estão fixados pela estrutura material e simbólica da sociedade, em determinado momento histórico. Neste 
campo educativo amplo, estão incluídas também as instituições (família, escola, igreja dentre outros), assim como o cotidiano difuso de trabalho, do bairro, do lazer entre outros (Costa-Pinto et al, 2001).

Visualiza-se diferentes dimensões em que pode se dar este processo educativo, retomando os "espaços e situações sociais" definidos por Dayrell (1996): a dimensão do cotidiano difuso de trabalho, do bairro, do lazer, e outra das instituições como as escolas, as associações de moradores, as ONGs, a administração pública.

Logo, esta pesquisa junto a AMPIC, procurou captar sinais para entender se foram desencadeados processos educativos e de que maneira os conhecimentos produzidos nestes diferentes espaços podem contribuir com novos olhares para a discussão a respeito EA e da sustentabilidade no seu sentido mais amplo (social, ambiental, cultural, democrática).

Isto implica compreender os grupos sociais locais como parceiros das instituições de pesquisa na busca por modelos de desenvolvimento que congreguem os objetivos da conservação e a melhoria das condições de vida destas populações. Neste contexto delineiam-se propostas em consonância com o que Santos (1999) chama de "comunidades interpretativas", em que universitários (professores, estudantes e funcionários) e comunidade estabelecem um confronto comunicativo de diferentes formas de saber (Costa-Pinto et al, 2001).

"Práticas sociais alternativas gerarão formas de conhecimentos alternativas. Não reconhecer estas formas de conhecimento implica deslegitimar as práticas sociais que as sustentam e, nesse sentido, promover a exclusão social dos que a promovam." (Santos, 1995, p.328).

As "comunidades interpretativas" buscam revalorizar saberes não científicos e, mesmo, revalorizar o próprio saber científico a partir de um modo de aplicação da ciência, alternativo ao modelo de aplicação técnica. Neste modelo alternativo, 
o "know-how" técnico está subordinado ao "know-how" ético e a aplicação se dá em uma situação concreta em que a comunidade científica esteja existencial, ética e socialmente comprometida com a aplicação (Santos, 1999).

Nestas comunidades interpretativas, os cidadãos não renunciam à sua própria interpretação da realidade sócio-ambiental para validar a interpretação científica. Ao invés disso, estabelece-se um diálogo entre as diferentes formas de interpretação (Santos, 1999).

O estabelecimento do confronto comunicativo coloca-se como potencialidade para deflagrar um processo de participação política à medida em que, além de desencadear a reflexão da comunidade sobre sua própria realidade, valoriza sua forma de análise e interpretação (Costa-Pinto et al, 2001).

Pádua \& Tabanez (1998) refletindo sobre UCs e comunidade local, concluem que é necessário que a preocupação com a temática ambiental esteja inserida em todos os segmentos da sociedade para que esta participe e apoie a conservação e valorização dessas áreas. $E$ mais que isso, na condição de residentes possam participar no que diz respeito ao seu futuro e consequentemente na melhoria da qualidade de suas vidas. Visualiza-se, portanto, nos trabalhos junto aos grupos locais, oportunidades riquíssimas para a reflexão sobre suas ações.

Daí a necessidade de se pensar caminhos para incentivar os grupos locais a conhecer os problemas do ambiente onde desenvolvem suas atividades, refletir sobre eles e visualizar os possíveis espaços de atuação, para que se possa efetivamente integrá-los a sua conservação.

\subsection{Sobre Participação}

Diante dos pressupostos de EA apresentados, cuja ênfase se coloca na busca da construção de espaços de decisão coletiva respeitando também os direitos individuais, a participação mostra-se como o eixo condutor na busca de sociedades mais democráticas e, consequentemente, mais sustentáveis. No 
entanto, nota-se uma enorme gama de interpretações que o conceito "participação" pode denotar, o que torna imprescindível decodificá-lo, buscando esclarecer os aspectos do tema que estão sendo considerandos.

O diálogo com Sorrentino (2000, p.101-103) permitiu destacar pelo menos cinco condições essenciais para a participação. A primeira a ser considerada é a da "infra-estrutura básica para a participação", isto implica em oferecer condições para que a pessoa possa, por exemplo, se deslocar para reuniões, ou seja, é principalmente uma questão de acesso. A segunda se refere a "disponibilização de informações", condição essencial para que se possa falar ou não em participação, o que implica a difusão de informações e as diversas posições a respeito do assunto em questão e que suscita automaticamente a terceira condição, que é a existência de "espaços de locução" pois de nada adianta a disponibilização das informações, que possam estar envolvidas com a temática, se não houverem espaços em que as pessoas possam dialogar sobre elas e “(...) trocar idéias, sentimentos e afetividades”.

A quarta dimensão salientada pelo autor é a que se refere à "tomada de decisão". Nem sempre é possível que todos participem de tudo o tempo todo, neste caso, é necessário deixar claro qual é o limite desta participação para que se criem mecanismos de representatividade em que haja definição de quais os limites de decisão para cada assunto e para cada grupo.

Por fim, a quinta e última condição apontada por Sorrentino (2000) é a do "pertencimento" que acaba adentrando o campo da subjetividade, pois não há participação sem compromisso e, portanto, de nada adianta infra-estrutura de acesso, disponibilização de informações, espaço de locução, possibilidades de tomada de decisão se o ser humano não estiver profundamente envolvido com as decisões sobre as questões ambientais, sentindo-se pertencente ao local, ao planeta, à humanidade, internalizando que tudo isto Ihe diz respeito.

Ao pensar a questão da subjetividade, olhando-a sob um prisma coletivo, nota-se que hoje em dia ela ocupa um lugar central para que se compreenda as questões sociais e se aprimore a práxis emancipatória. 
Para Sawaia (2000), a subjetividade tornou-se uma das idéias-força do espírito de nossa época (Zeitgeist),

"Nos anos 80, participação adquire um sentido mais subjetivo e menos estrutural e a objetividade e o coletivo cedem lugar à preocupação com a individualidade e a afetividade. Autonomia, emancipação e diversidade tornam-se os valores éticos mais aplaudidos em substituição à liberdade e à igualdade. $\mathrm{O}$ espaço da participação social perde as fronteiras rígidas $\mathrm{e}$ a sua temporalidade deixa de ser delimitada pelas ações políticas pontuais, tornando-se o tempo do cotidiano.

Estas mudanças são positivas, na medida que superam a dicotomia entre razão e emoção, entre o público e o privado e o reducionismo estrutural que vê a participação como algo fora do sujeito" (Sawaia, 2000, p. 2).

A Sawaia alerta também sobre os riscos da instrumentalização que cercam a categoria da subjetividade incorrer em um grande equívoco: a do "solopsismo individualista que reduz a participação a uma ação de foro íntima, contrapondo-se ao coletivo, como se o interior de cada um fosse o reduto exclusivo de exercício de liberdade, justiça e felicidade".

Para a autora a participação não está fora do indivíduo, independente de sua subjetividade, mas subjetividade e objetividade se interconstituem.

"O que eqüivale afirmar que não há participação sem subjetividade, nem subjetividade sem participação. Ambas são fenômenos da mesma substância, de forma que, para mudar a qualidade da participação, é preciso mudar a ontologia da subjetividade. A separação entre elas foi contigencialmente imposta pela epistemologia cindidora, pelo raciocínio reducionista da causalidade simples e pela ontologia da renúncia (ou do homem a reboque da sociedade), tendo de renunciar a seus desejos 
para viver em sociedade, como se a felicidade pessoal e o bem-estar coletivo fossem antagônicos." (Sawaia, 2000 p.122).

Portanto, dentro desta lógica, há uma valorização do sujeito que:

“(...) afetado por outros é o sujeito do afeto e da paixão que sente e interpreta o mundo nas diferentes formas de participação. $O$ ato de participação desse sujeito é determinado pelos modelos dominantes de participação social, mas é organizado num contexto de subjetividade como experiência existencial, impregnada de emotividade" (Sawaia, 2000 p. 122-123). 


\section{METODOLOGIA}

Dialogando com a literatura sobre abordagens qualitativas de pesquisa, pesquisa-intervenção e planejamento incremental articulado, o método desta pesquisa foi sendo construído.

Segundo Becker, o caminho é idiossincrático, logo o método se faz ao andar:

"Os princípios gerais (...) de metodologia são uma ajuda, mas sendo genéricos, não levam em consideração as variações locais e peculiaridades que tornam este ambiente e este problema aquilo que são de modo único" (Becker, 1993:13).

O diálogo com estas metodologias ocorreu principalmente dentro de um grupo de pesquisa que constitui o componente Intervenções e Educação Ambiental do projeto temático Floresta \& Mar, em que se insere esta pesquisa. A compreensão da dinâmica deste grupo é fundamental para que se possa entender como o método foi sendo construído e os pressupostos a ele relacionados. Portanto, será apresentada uma rápida trajetória deste grupo, buscando salientar os momentos que, para esta pesquisa, foram imprescindíveis fazer parte dele.

Além disso, será feita uma descrição dos métodos e técnicas que alimentaram esta pesquisa e posteriormente, os caminhos trilhados para sua realização. 


\subsection{Sobre o grupo de Intervenções e Educação Ambiental}

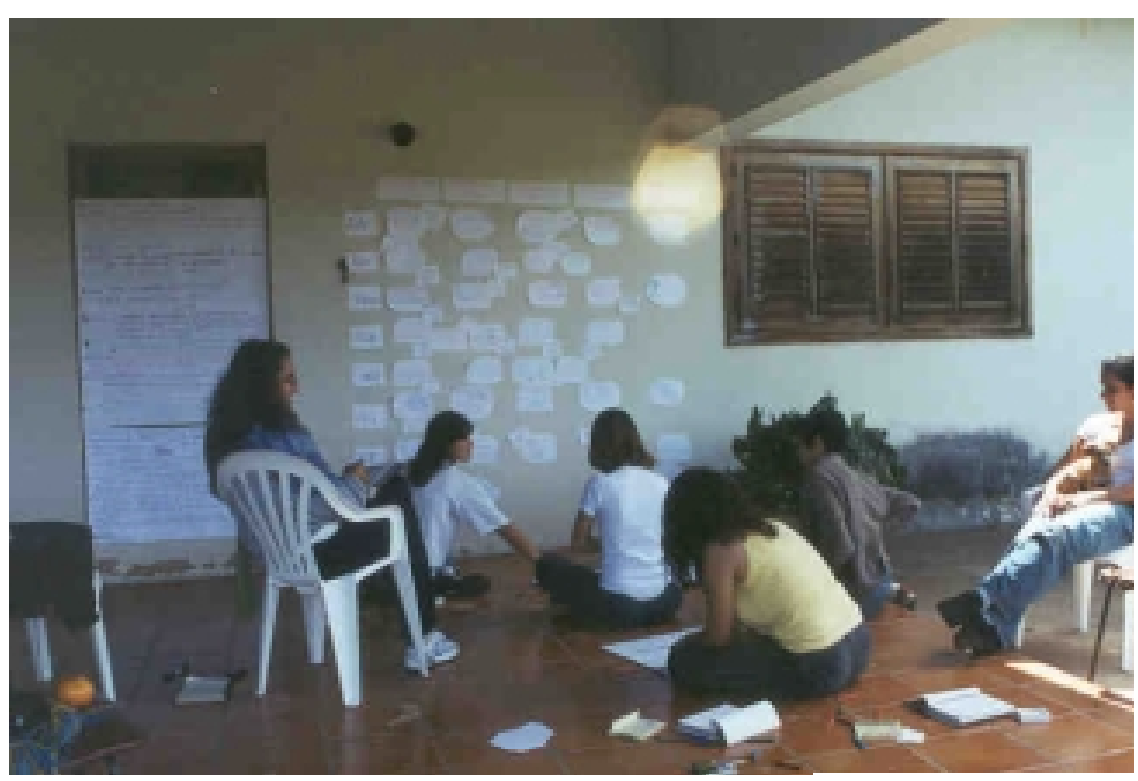

Foto: Vivian G. Oliveira

Figura 5 - Grupo de EA - Oficina de Planejamento de Atividades.

O grupo que constitui o componente Intervenções e Educação Ambiental do projeto temático Floresta \& Mar $^{1}$ começou a formar-se no início de 1999, quando o projeto temático foi aprovado pelo órgão financiador (FAPESP). Naquela ocasião, embora as integrantes do componente ainda estivessem pensando suas pesquisas, tinha-se em comum manter uma coerência entre os princípios teóricos e metodológicos adotados nos projetos de pesquisa e intervenção educativa e os princípios de gestão do grupo de trabalho: metodologias participativas, nãohierarquia dos saberes e o entendimento do grupo como um espaço de reflexão e produção coletiva do conhecimento.

Durante o ano de 1999, o grupo realizou viagens de campo às localidades de abrangência do projeto temático, para que cada uma pudesse conhecer melhor a realidade do Vale do Ribeira, e assim optar por seu objeto de pesquisa. Estabeleceu-se contato com diversas entidades locais como: Organizações não

\footnotetext{
${ }^{1}$ Adiante estará sendo utilizada a expressão "grupo de EA" para referir-se aos trabalhos desenvolvidos por este componente.
} 
governamentais (Ong's), escolas, associações comunitárias, prefeituras, órgão ambiental federal (IBAMA), buscando-se conhecer as atividades que a população local já desenvolvia, para então contribuir no fortalecimento destas ações, principalmente pelo estabelecimento de parcerias através dos projetos a serem desenvolvidos.

Deparou-se com diferentes oportunidades para tais parcerias e cada uma das integrantes fez sua opção de pesquisa ou com grupos de moradores ou em escolas da região do Vale do Ribeira, de acordo com seus desejos e indagações.

Nestes três anos de existência do grupo, os encontros ocorrem com a periodicidade média de quinze dias, as leituras e discussões teóricas são permeadas pelos relatos da prática dos projetos que estão em andamento com as comunidades e escolas do Vale do Ribeira. As trocas coletivas dão suporte à construção de um conhecimento que vai além do que a reflexão individual possibilitaria em determinado momento.

Nos mergulhos individuais, cada pesquisadora tem seu projeto com seus questionamentos próprios e com as reflexões e aprofundamento teóricos que the dão sustentação. Estes projetos, a partir de seu acontecer dinâmico, alimentam os questionamentos do grupo de pesquisa e embasam as reflexões teóricas do mesmo nos encontros chamados de "orientação coletiva" (Avanzi et al, 2001).

Além dos encontros quinzenais, o grupo realizou também retiros (em média de três dias) para aprofundamento teórico, entrelaçamento dos projetos, planejamento semestral/anual, tanto das ações individuais como do grupo, e elaboração de relatórios.

A preocupação com o conteúdo dos registros seja na coleta de dados de campo ou nos encontros do grupo ou na elaboração de textos para publicações, mereceu uma atenção especial. Houve, em três oportunidades a realização de oficinas específicas, mediadas pela Profa. Ms Eliana Kefalas Oliveira $^{2}$, visando para discussão e aprofundamento dos registros.

\footnotetext{
${ }^{2}$ Professora da Universidade de Uberaba e mestranda pela FE da Unicamp.
} 
O referencial metodológico que embasa os trabalhos desenvolvidos pelo grupo de EA vai ao encontro dos princípios da pesquisa-ação que, segundo Thiollent (1986), é uma metodologia de pesquisa voltada para a descrição de situações concretas e para intervenção ou a ação orientada em função da resolução de problemas efetivamente detectados nas coletividades consideradas, ou seja a partir de demandas específicas (Avanzi et al, 2001).

Uma das dimensões do processo desencadeado pelo e no grupo consiste em estimular "a capacidade de atuação, individual e coletiva, de forma a contribuir para que o mesmo ocorra com as pessoas e grupos com os quais atuam" (Sorrentino, 2000: 35). O processo de desenvolvimento das próprias capacidades compõe-se da descoberta dos recursos internos de cada um e sua manifestação como potenciais catalisadores de uma transformação sócio-ambiental (Avanzi et al, 2001).

Com esta opção metodológica - partindo de demandas locais - partilha-se das idéias de alguns autores que consideram que "não basta criar um novo conhecimento, mas é fundamental que alguém se reconheça nele" (Tassara, 1996:53). Ainda segundo esta autora, para criar alternativas de realização pessoal e coletiva, estas devem ser apropriáveis por aqueles a quem se destinam.

A identificação das demandas coletivas não ocorre visando apenas a resolução de problemas concretos, tem também como objetivos incentivar o desenvolvimento autônomo, autoconfiante (Borda, 1981) e principalmente o desencadeamento de um processo reflexivo sobre a realidade em que está inserido aquele grupo social.

Desta forma, os propósitos do trabalho do grupo e os individuais encontramse em consonância com aqueles da pesquisa participante e da pesquisa-ação. Há, inclusive, autores que se utilizam da expressão Pesquisa Ação Participante (Thiollent, 1986, Sawaia, 1987, Viezzer \& Ovalles, 1995).

Haguette (1987) destaca algumas exigências que esta proposta requer do pesquisador "uma postura de analisador, moderador, intérprete, animador". 
O grupo de EA representou uma possibilidade de partilhar as dúvidas e inseguranças que desapontam no desenrolar de um processo de pesquisa que utiliza esta metodologia.

A leitura de Costa (1986), que apresenta o planejamento incremental articulado, também reconforta as inseguranças que podem despontar durante este processo. Trata-se de um modo de planejar que considera a maneira gradual pela qual se dão as mudanças, em que cada passo dado desenha o passo seguinte.

Portanto, para o desenvolvimento desta pesquisa foi extremamente importante a experiência de fazer parte de um grupo de discussões, que através do diálogo, tem propiciado a aquisição de novos repertórios. Os processos pedagógicos desencadeados vão além do que a pesquisa individual por si desencadearia. A troca entre pesquisadoras comprometidas com processos educativos/emancipatórios, cujo eixo condutor é a postura democrática, o respeito ao outro, o saber ouvir e generosamente acolher, foi fundamental para este trabalho.

\subsection{Referenciais Metodológicos}

\subsubsection{Pesquisa Qualitativa}

Sobre a pesquisa qualitativa, Lüdke e André (1986) apresentam cinco características básicas que servem como referencial:

"1. ter seu ambiente natural como fonte direta de dados e o pesquisador como seu principal instrumento; 2 . os dados coletados são predominantemente descritivos como descrição das pessoas, situações, acontecimentos, incluindo descrições de entrevistas, depoimentos, fotografias, desenhos e documentos; 3. a preocupação com o processo é muito maior do que com o produto; o "significado" que as pessoas dão "as 
coisas” e `a sua vida são focos especiais do pesquisador; 4.0 pesquisador deve estar atento para captar a "perspectiva dos participantes", ou seja, como eles encaram as questões que estão sendo enfocadas; 5. a análise dos dados tende a seguir um processo indutivo. Isso não significa portanto a inexistência de um quadro teórico que oriente a coleta e a análise dos dados“ (Ludke \& André, 1986:11).

Dentro da abordagem qualitativa, destacam-se o estudo de caso e a pesquisa do tipo etnográfica, ambos muito úteis para o desenvolvimento desta pesquisa.

Cabe ressaltar também alguns princípios da pesquisa-intervenção educacional e do planejamento incremental que, como dito anteriormente, estiveram presentes no delineamento dos passos desta dissertação.

\section{a) Sobre o Estudo de Caso}

O estudo de caso tem como estrutura básica a compreensão de uma unidade dentro de um sistema amplo de dimensões complexas, ou seja, é o estudo de um caso que deve ser bem delimitado, com contornos claramente definidos, cujo interesse centra-se no que ele tem de exclusivo, considerando-se o contexto em que está inserido.

Segundo Triviños, (1987) o estudo de caso “(...) É uma categoria de pesquisa cujo objeto é uma unidade que se analisa profundamente."

'O termo 'estudo de caso' vem de uma tradição de pesquisa médica e psicológica, onde se refere a uma análise detalhada de um caso individual que explica a dinâmica e a patologia de uma doença dada; o método supõe que se pode adquirir conhecimento do fenômeno adequadamente a partir da exploração intensa de um único caso. Adaptado da tradição médica, o estudo de caso tornou-se uma das principais modalidades de análise das ciências sociais. (...) o cientista social que realiza um estudo 
de caso de uma comunidade ou organização tipicamente faz uso do método de observação participante em uma de suas muitas variações, muitas vezes em ligação com outros métodos mais estruturados, tais como entrevistas"(Becker, 1993).

A seguir estarão sendo apresentadas as características fundamentais dos estudos de caso a partir da leitura de Ludke \& André, 1986:

1 “...visam a descoberta - mesmo que o pesquisador parta de pressupostos teóricos iniciais, ele procurará se manter atento a novos elementos que podem emergir como importantes durante o estudo. $O$ quadro teórico inicial servirá assim de esqueleto, de estrutura básica a partir da qual novos elementos ou dimensões poderão ser acrescentadas, na medida em que o estudo avance.

2 Enfatizam a 'interpretação de um contexto' para uma apreensão mais completa do objeto, é preciso levar em conta o contexto em que ele se situa.

3 Buscam retratar a realidade de forma completa e profunda. $O$ pesquisador procura revelar a multiplicidade de dimensões presentes numa determinada situação ou problema, focalizando-o como um todo.

4 Usam uma variedade de fontes de informação - recorre a uma variedade de dados, coletados em diferentes momentos, em situações variadas e com uma variedade de tipos de informantes.

5 Permitem 'generalizações naturalísticas' - o pesquisador procura relatar as suas experiências durante o estudo de modo que o leitor possa fazer as suas próprias generalizações em função da seu conhecimento experiencial.

6 Procura representar os diferentes, e, às vezes conflitantes, pontos de vista presentes numa situação social, Quando o objeto e situações podem 
suscitar opiniões divergentes. Permitindo que o pesquisador revele ainda o seu próprio ponto de vista.

7 Os relatos utilizam uma linguagem e uma forma mais acessível do que os outros relatórios de pesquisa" (Ludke \& André, 1986: 18-20).

\section{b) Etnografia}

Na leitura de Ludke \& André (1986) a etnografia trata da "descrição de um sistema de significados culturais de um determinado grupo" e parte de dois pressupostos:

"A hipótese naturalista-ecológica, que afirma ser o comportamento humano significativamente influenciado pelo contexto em que se situa. - a hipótese qualitativo-fenomenológica, que determina ser quase impossível entender o comportamento humano sem tentar entender o quadro referencial dentro do qual os indivíduos interpretam seus pensamentos, sentimentos e ações".

Para Geertz (1989) a "etnografia é uma descrição densa". O autor define as circunstâncias com as quais um etnógrafo pode defrontar-se ao longo da pesquisa:

“(...) o que o etnólogo enfrenta, de fato - a não ser quando (como deve fazer naturalmente) está seguindo as rotinas mais automatizadas de coletar dados - é uma multiplicidade de estruturas conceptuais complexas, muitas delas sobrepostas ou amarradas umas as outras, que são simultaneamente estranhas, irregulares e inexplícitas, e que ele tem que, de alguma forma, primeiro apreender e depois apresentar. (...) Fazer a etnografia é como tentar ler (no sentido de 'construir uma leitura de') um manuscrito estranho, desbotado, cheio de elipses, incoerências, emendas 
suspeitas e comentários tendenciosos, escrito não com os sinais convencionais do som, mas com exemplos transitórios de comportamento modelado" (Geertz, 1989, p:20).

\subsubsection{Sobre a pesquisa-intervenção educacional}

A pesquisa intervenção educacional, pode ser uma intervenção para solução de um problema específico e/ou uma intervenção educacional.

Toda intervenção educacional é para a solução de problemas mas nem toda intervenção para solução de problemas se propõe a ser educacional.

A intervenção pode ser através do pesquisar (participativamente ou não) e/ou pode ser uma pesquisa sobre a intervenção, relatando o seu processo e/ou avaliando-se os seus impactos.

A pesquisa-ação (Thiollent, 1986; Haguette, 1999) e a pesquisaparticipante (Borda, 1990; Haguette, 1999) são duas modalidades com as quais dialóga a pesquisa-intervenção.

Para Thiollent (1986) toda pesquisa ação é participante, mas nem toda pesquisa participante é ação. Segundo o autor é possível realizar pesquisas diagnósticas/avaliativas em que os pesquisados são pesquisadores, mas não existe compromisso com ação, mas sempre que houver ação há um compromisso com a participação.

A pesquisa intervenção educacional pode envolver o público ao qual se destina como sujeitos do pesquisar, mas pode não envolvê-los de forma ativa, portanto pode não ser a ação do participante, mas só do agente externo.

Quanto à pesquisa-ação, devido ao seu aspecto de intervenção direta no problema estudado, é importante esclarecer sua estratégia metodológica:

“a) há uma ampla e explícita interação entre pesquisadores e pessoas implicadas na situação investigada; b) desta interação resulta a ordem de prioridade dos problemas a serem pesquisados e das soluções a serem 
encaminhadas sob forma de ação concreta; c) o objeto de investigação não é constituído pelas pessoas e sim pela situação social e pelos problemas de diferentes naturezas encontrados nesta situação; d) 0 objetivo da pesquisa-ação consiste em resolver ou, pelo menos, em esclarecer os problemas da situação observada; e) há, durante o processo, um acompanhamento das decisões, das ações e de toda a atividade intencional dos atores da situação; f) a pesquisa não se limita a uma forma de ação (risco de ativismo): pretende-se aumentar o conhecimento dos pesquisadores e o conhecimento ou 'nível de consciência' das pessoas e grupos considerados" (Thiollent ,1986:16).

Segundo Borda (1981), a pesquisa participante é:

“(...) uma pesquisa da ação voltada para as necessidades básicas do indivíduo' (Huynh, 1979) que responde especialmente às necessidades de populações (...) mais carentes nas estruturas sociais contemporâneas, que procura incentivar o desenvolvimento autônomo (autoconfiante) a partir das bases e uma relativa independência do exterior "

\subsubsection{Planejamento Incremental Articulado}

Sobre o planejamento incremental articulado é importante salientar os pontos sobre os quais se baseia esta estratégia de planejamento:

“1. Nenhum sistema social pode ser transformado de uma vez, partindo de um estado inicial e chegando a um estado desejado. A transformação tem de ser gradual e cada mudança real que ocorre no sistema pode modificar a definição do estado desejado. 2. As características do estado desejado devem ser estabelecidas de modo a se constituírem em critérios que permitam a avaliação de cada mudança incremental. Estas 
características fornecem uma direção geral que articula as ações tomadas. "

(...) A estratégia procura criar condições para que um sistema aprenda a planejar interativamente, (...) incluindo as características de participação, coordenação, integração e continuidade” (Costa, 1986 p:1369 e 1370 ).

\subsection{A Coleta e análise dos dados}

Para desenvolver a pesquisa utilizou-se técnicas de coleta de dados como: observação participante, entrevistas semi-estruturadas e análise documental.

Pode-se dizer que isto possibilitou, na fase de análises uma triangulação de técnicas diferentes e de dados. Triviños (1987) define o objetivo desta técnica:

"A técnica da triangulação tem por objetivo básico abranger a máxima amplitude na descrição, explicação e compreensão do foco em estudo. Parte-se de princípios que sustentam que é impossível conceber a existência isolada de um fenômeno social, sem raízes históricas, sem significados culturais e sem vinculações estreitas e essenciais com a macrorrealidade social" (Triviños, 1987p:138).

Este autor destaca que o interesse do pesquisador deve centrar-se em três aspectos principalmente:

O primeiro deles seria os "Processos e Produtos elaborados pelo pesquisador", que segundo o autor buscam averiguar as percepções do sujeito através de entrevistas, comportamentos e ações do sujeito, mediante a observação livre ou dirigida. O segundo ângulo de enfoque seria os "Elementos Produzidos pelo Meio", sendo representado pelos Documentos, instrumentos legais; instrumentos oficiais, atas de reuniões. A terceira perspectiva de análise seria o que o autor chama de Processos e "Produtos originados pela estrutura 
sócio-econômica e cultural do macroorganismo social no qual está inserido o sujeito" Triviños (1987 p:139).

Segue uma pequena descrição sobre as técnicas utilizadas.

\subsubsection{Observação participante}

Denzin (1978) define observação participante como sendo "uma estratégia de campo que combina simultaneamente a análise documental, a entrevista de respondentes e informantes, a participação e a observação direta e a introspeção". É uma estratégia que envolve, portanto, não só a observação direta mas todo um conjunto de técnicas metodológicas pressupondo um grande envolvimento do pesquisador na situação estudada.

Para a utilização desta técnica é necessário um controle sistemático para o levantamento das informações, isto implica na elaboração de um planejamento cuidadoso do observador/pesquisador.

Planejar a observação significa determinar com antecedência "o que" e "o como" observar. A primeira tarefa é delimitar o objeto de estudo, definindo claramente o foco da investigação e sua configuração espaço-temporal. Com isso ficam mais claros quais aspectos do problema serão cobertos pela observação e qual a melhor forma de captá-los. É importante também definir o grau de participação e duração da observação (Ludke \& André, 1986).

Os registros das observações podem ser feitos através de anotações escritas e a combinação com material transcrito de gravações, foto ou outros equipamentos (Ludke \& André, 1986). Sorrentino (1995) ressalta a importância dos registros durante a pesquisa.

“(...) Importância não só para avivarmos nossa memória na recomposição da história, unindo fatos e datas, mas principalmente para (re)descobrirmos as descobertas que íamos fazendo ao longo da 
militância e seu significado, em nível individual e de nossa prática social” (Sorrentino, 1995, p.86 e 87).

\subsubsection{Análise documental}

Ludke \& André (1986:38) salientam a importância da análise documental na abordagem de dados qualitativos "(...) seja complementando as informações obtidas por outras técnicas, seja desvelando aspectos novos de um tema ou problema".

Através da utilização desta ferramenta é possível “(...) identificar informações factuais nos documentos a partir dos interesses da pesquisa. Por exemplo legislação, estatuto (regulamentos, normas), pareceres, relatórios técnicos, jornais, discurso" (Ludke \& André, 1986).

Conforme as considerações de Triviños (1987) que serão apresentadas posteriormente, os documentos trazem importantes contribuições para buscar compreender a complexidade do tema em estudo.

\subsubsection{Entrevistas}

$\mathrm{Na}$ entrevista a relação que se cria é de interação, havendo uma atmosfera de influência recíproca entre quem pergunta e quem responde.

Em pesquisas com enfoque qualitativo, pode-se usar a entrevista estruturada, ou fechada, a semi-estruturada e a entrevista livre ou aberta

Nesta pesquisa priorizou-se a utilização de entrevistas semi-estruturadas.

“...não há imposição de uma ordem rígida de questões, o entrevistado discorre sobre o tema proposto com bases nas informações que ele detém e que no fundo são a verdadeira razão da entrevista. Se desenrola a partir de um esquema básico, porém não aplicado rigidamente, 
permitindo que o entrevistador faça as necessárias adaptações" (Ludke \& André, 1986:34).

\subsection{A chegada na llha Comprida}

Durante o primeiro semestre de 1999, a pesquisadora participou de um estudo realizado por um grupo na APA de Ilha Comprida sobre uso e ocupação do solo ${ }^{3}$. Naquela ocasião foi possível contatar vários segmentos sociais locais como: poder público municipal, técnicos de órgãos estaduais e federais, lideranças políticas, turistas e sociedade civil, o que proporcionou tomar conhecimento da existência do projeto de Manejo Participativo de Samambaias Silvestres da Ilha Comprida. Os contatos estabelecidos naquele período facilitaram o retorno à llha Comprida para realização desta pesquisa de mestrado.

É interessante ressaltar também que o fato do grupo de EA e mesmo de outros pesquisadores do projeto Floresta \& Mar já serem conhecidos pelos moradores das diferentes localidades do Vale do Ribeira, contribuiu muito para o avanço desta pesquisa, no sentido de proporcionar uma aproximação mais rápida com os grupos locais.

No segundo semestre de 1999, durante as primeiras viagens de campo realizadas pelo grupo de EA, em que se buscava conhecer as atividades que já ocorriam nos locais de abrangência do projeto Floresta \& Mar, a pesquisadora optou então por estudar a formação da AMPIC, sua parceria junto ao poder local como forma de institucionalização do manejo.

Desde seu início, a pesquisa foi desenvolvida pensando-se numa intervenção educacional. A intervenção foi planejada para ter dois momentos: o primeiro, ao longo de todas as atividades relacionais/comunicativas, ocorridas durante as atividades de campo, e a segunda, como um momento formal de avaliação crítica do processo de institucionalização do manejo.

\footnotetext{
${ }^{3}$ Trabalho de conclusão do curso de especialização em Análise de Usos e Conservação de Recursos Naturais oferecido pelo NEPAM da Unicamp.
} 
O primeiro momento de coleta de dados da pesquisa de campo (primeiro semestre de 2001) iniciou-se com um "olhar distraído", em que se buscava compor um pré-cenário a partir de conversas informais, que iam sendo registradas em caderno de campo, com pessoas que de algum modo tivessem uma relação mais estreita com o processo de constituição da AMPIC e institucionalização do manejo de samambaias. As pessoas procuradas foram: o Engenheiro. Agrônomo responsável pela organização da AMPIC, o prefeito municipal e funcionários do Departamento de Ecologia e Pesca da Prefeitura Municipal de llha Comprida.

Estes contatos iniciais propiciaram a visualização do panorama geral do contexto em que se formou a AMPIC e se institucionalizou o manejo. Além destas conversas iniciais, houve a possibilidade de acesso a dados secundários como lista com os nomes e localidades de cada extrator, os relatórios técnicos da pesquisa realizada pelos pesquisadores da Universidade Federal de Santa Catarina (UFSC) sobre a biologia da espécie extraída, transcrições de reuniões que já haviam sido realizadas pelos extratores e parceiros, documentos de licença de extração emitidos pelo IBAMA.

Todos os funcionários e técnicos contatados nas diferentes etapas da pesquisa sempre mostraram-se extremamente dispostos a ajudar no levantamento de dados, facilitando o acesso a documentos, mapas, publicações, relatórios ou mesmo relatos. Além disso, se propuseram-se a facilitar o deslocamento dos extratores para a possível realização de uma intervenção formal.

A partir dos primeiros levantamentos, a pesquisadora foi em busca de contatar os extratores, que passaram então a ser os protagonistas da pesquisa, e desta forma levantar novos elementos que pudessem dar um panorama mais detalhado dos processos participativos.

\footnotetext{
${ }^{4}$ Expressão usada pelo professor Marcos Sorrentino, da Esalq/Usp, para uma primeira aproximação junto aos atores envolvidos na pesquisa.
} 
A intenção inicial era contatar todos os extratores em atividade. De posse da lista com a identificação dos extratores, deparou-se com o primeiro "nó" da pesquisa: Quais extratores contatar? Quantos?

Esta primeira dúvida surgiu em função do número de extratores cadastrados (cerca de 150 pessoas) e principalmente pela dificuldade de acesso a eles (a llha apresenta $74 \mathrm{Km}$ de comprimento e as residências dos extratores estão distribuídas ao longo de toda ela), portanto estes foram os primeiros fatores limitantes para este contato. Como selecioná-los? O acesso a cada um individualmente seria extremamente complicado e reuni-los só seria possível através de uma convocação formal por parte da prefeitura, que facilitaria este momento.

Desta forma, o planejamento inicial teve que ser repensado, adequado ao contexto. A opção tomada pela pesquisadora - depois de conversas com outras pesquisadoras do grupo de EA - foi de focar principalmente os extratores de Pedrinhas - bairro onde concentra-se $60 \%$ da comunidade caiçara da llha Comprida.

Das idas a campo é importante salientar que, com exceção da última viagem realizada em janeiro/2002, em todas as outras a pesquisadora não esteve sozinha mas sempre acompanhada por no mínimo mais uma pesquisadora do grupo de EA que estavam sempre atentas para quaisquer elementos que pudessem contribuir com os dados da pesquisa. Esta troca de impressões entre as pesquisadoras, possibilitou um enriquecimento nos processos interpretativos da realidade extrativista, já que muitos dados eram discutidos in loco assim que levantados e desta forma permitiram que os passos da pesquisa fossem sendo redesenhados quando necessário. 


\subsubsection{A chegada em Pedrinhas}

A chegada ao bairro de Pedrinhas foi extremamente facilitada pois haviam pesquisadores do projeto grupo Floresta \& Mar que já realizavam pesquisa no bairro e portanto tinham estabelecido relações de confiança com pessoas da comunidade.

Estes pesquisadores, que já vinham desenvolvendo pesquisas no bairro, indicaram então alguns extratores para o começo da coleta de dados.

Iniciam-se contatos informais junto aos extratores do bairro de Pedrinhas (a maioria mulheres entre 40 e 65 anos), que se mostraram interessadas em contribuir no levantamento de dados. A princípio estes contatos ocorriam através de conversas informais na casa dos extratores (o que era previamente combinado) ou em encontros casuais nas ruas do bairro.

Nesta etapa da pesquisa o que se buscava era principalmente compreender as mudanças ocorridas após a formação da AMPIC e o estabelecimento do manejo participativo de samambaias. Portanto, as perguntas que nortearam as observações e conversas nesta fase ganhavam estes contornos: como era a atividade extrativista antes do estabelecimento da APA? como passou a ser após o seu estabelecimento (período de clandestinidade) e como está funcionando atualmente? Buscava-se também onde haviam nascido, o tempo de envolvimento com o extrativismo e com as outras atividades que realizam além da extração.

Além das conversas, e posteriormente as entrevistas, era preciso um mergulho mais profundo no universo da extração, para isto o acompanhamento do cotidiano das extratoras e, principalmente, da prática extrativista foi extremamente importante. 


\subsubsection{O cotidiano da extração}

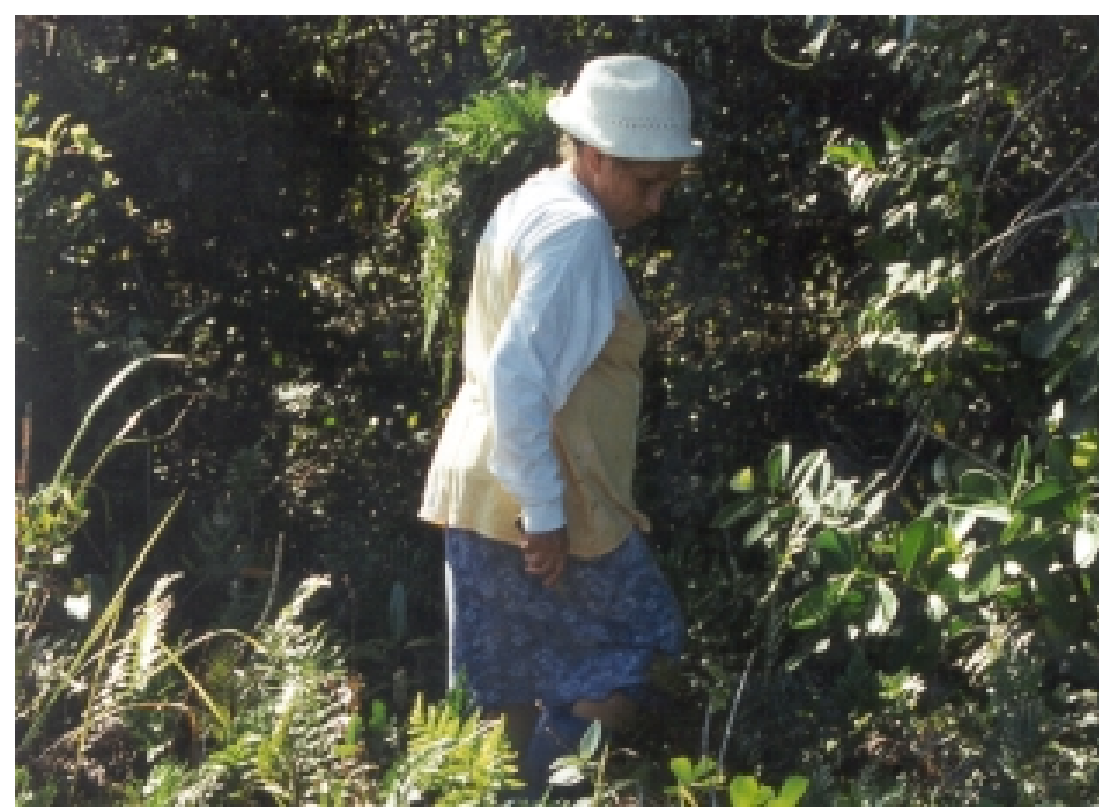

Figura 6 - Extratora na restinga.

Foto: Alessandra B. Costa Pinto

O acompanhamento do cotidiano do bairro permitiu perceber um pouco a dinâmica de atividades das extratoras, ou seja, como conciliam as tarefas domésticas com as demais atividades que desenvolvem, seus costumes, a forma de organização das mulheres para as atividades extrativistas, o que preparam para comer, o que deixam para a família, o horário de saída, a distância que percorrem até o ponto de extração e principalmente dados relacionados à extração propriamente dita, que serão discutidos no capítulo 4.

Após as conversas informais em que o cotidiano das extratoras pode ser percebido, notou-se ser importante não só ouvi-las mas também acompanhá-las nas atividade extrativista. Fez-se então um pedido (por parte da pesquisadora) para ajudá-las em uma manhã de extração o que imediatamente foi aceito pelas extratoras. 
Para o acompanhamento desta atividade extrativista, no dia anterior a ela houve todo um ritual de preparação. As extratoras não cansavam de atentar sobre o uso de roupas adequadas para a ida "pro mato", visto que nos locais de extração é comum a presença de inúmero insetos, portanto este tipo de precaução é significativa, além dos cuidados que se deve ter em relação a animais peçonhentos.

$\mathrm{Na}$ manhã combinada, lá estavam elas (quatro extratoras) nos locais combinados e partiu-se para a extração. A distância deslocada até o ponto de extração é de cerca de três quilômetros e meio.

As idas para o mato foram muito interessantes, pois possibilitaram saber um pouco mais da vida destas mulheres, suas relações de parentesco, suas crenças religiosas, seus passados e, principalmente, perceber que apesar de terem levado uma vida dura, sem recursos, com inúmeras dificuldades, transborda delas uma alegria contagiante.

A partir das conversas informais, das idas para o mato, dos almoços que passaram a oferecer, os laços de confiança e amizade foram se estreitando.

Nesta fase então, começou-se a realizar entrevistas semi-estruturadas gravadas, levantando principalmente o histórico da extração e já era colocado às extratoras a proposta de realização de uma intervenção formal para avaliação crítica dos dois anos de constituição da AMPIC.

No momento em que as informações começaram a se repetir, embora os informantes apresentassem pontos de vista diferentes, a necessidades de dados de outras fontes começaram a se tornar necessários, e a cada ida a campo havia um retorno à prefeitura para mais uma vez contatar técnicos e funcionários ligados à extração. As informações coletadas junto às extratoras de Pedrinhas eram então complementadas ou confirmadas pelos técnicos, prefeito e funcionários envolvidos com a extração, da mesma forma as informações destes eram confirmadas ou complementadas pelas extratoras. Todas as impressões, observações, conversas não gravadas eram registradas em caderno de campo. 
Os contatos com extratores de outras localidades ocorreram de duas maneiras, seja aproveitando o trajeto feito pelo caminhão da prefeitura ao longo de toda a llha para recolher, pagar e transportar as samambaias extraídas para serem comercializadas, seja através da ida a bairros próximos a Pedrinhas em companhia de uma senhora extratora muito conhecida e respeitada no município. Chegar em outro bairro junto com uma pessoa da comunidade facilita muito o acesso, pois a primeira barreira da desconfiança/desconhecimento pôde ser amenizada.

A viagem de caminhão ao longo da llha, além do contato com extratores de outras localidades, foi também um momento importante de conversa com 0 motorista e com o engenheiro agrônomo que semanalmente relacionam-se com os extratores, ampliando assim a gama de informações.

À medida que os dados iam sendo levantados, a necessidade de uma intervenção formal anunciada se mostrava mais contundente e então, da conversa com a funcionária da prefeitura responsável pela organização da AMPIC, estabeleceu-se uma parceria inicial daquela instituição com a pesquisadora, juntamente com o grupo de EA para sua realização. Previa-se também num momento futuro, a partir da análise crítica feita pelos extratores, técnicos e políticos durante a intervenção, viabilizar os desdobramentos que esta pudesse desencadear.

Em duas oportunidades a intervenção foi marcada pela prefeitura e desmarcada dias antes de ser realizada. Os motivos foram sempre de caráter interno da prefeitura. Esta intervenção será realizada ainda no primeiro semestre de 2002, mas é considerada pela pesquisadora como um desdobramento deste trabalho, pois não haverá prazo para sua realização. Mesmo assim, a proposta de intervenção foi pensada por integrantes do grupo de EA e suas etapas estarão dispostas no capítulo 5 desta dissertação. 


\subsection{Proposta de Intervenção}

Esta proposta de intervenção formal foi elaborada na ocasião em que foi marcada uma reunião para uma avaliação crítica dos parceiros na extração, sobre dois anos de formação da AMPIC e institucionalização do manejo participativo. Além da avaliação, algumas pendências da associação, elencadas em reuniões anteriores, necessitavam ser encaminhadas, como por exemplo: uma nova eleição, uma redefinição das áreas de extração, algumas mudanças no estatuto etc.

Em conversa com a responsável da prefeitura pelo manejo, a necessidade de realização de uma reunião entre os envolvidos no manejo era imprescindível, e as entrevistas com os extratores confirmavam que este também era um desejo dos mesmos.

A Prefeitura disponibilizaria o transporte para locomoção dos extratores e o lanche que seria servido. Pesquisadoras do grupo de EA mediariam a reunião. Esta opção de mediação por pessoas de fora foi uma necessidade detectada principalmente pela Prefeitura por achar que os extratores se sentiriam mais à vontade para expressar suas opiniões em relação às reuniões mediadas por técnicos ou por políticos locais.

A intervenção teria como objetivo desencadear processos reflexivos dos associados sobre o andamento do manejo, identificando seus fatores limitantes e potencializadores; discutir a parceria junto à prefeitura local e ainda sobre suas práticas extrativistas.

A experiência do grupo de $E A$, ao longo destes mais de dois anos de trabalhos no Vale do Ribeira junto a grupos de moradores locais, tem demonstrado que as metodologias participativas podem ser um instrumento político importante no processo de democratização da tomada de decisão e na gestão de problemas. Uma das pesquisas de mestrado realizada por uma 
pesquisadora do grupo ${ }^{5}$ junto a agricultores de Pedrinhas, vem estudando os processos participativos deflagrados a partir da formação de um grupo de trabalho e implantação de uma horta comunitária. As intervenções (reuniões e dias de trabalho na horta - ajutórios ${ }^{6}$ ) foram fundamentais para o estabelecimento de uma relação de trabalho conjunto entre os agricultores e, principalmente, para desencadear neles um sentimento de pertencimento e participação nos processos de tomada de decisão relacionados à horta.

Em função dos desdobramentos da parceria entre a AMPIC e a prefeitura, a intervenção formal não pode acontecer no período de realização desta dissertação, em função dos prazos estabelecidos pela universidade, porém está prevista para acontecer ainda para no primeiro semestre de 2002. Os resultados desta intervenção formal serão relatados através de artigos que serão publicados futuramente.

\footnotetext{
${ }^{5}$ Alessandra Buonavoglia Costa Pinto, mestranda do PROCAM/USP - cuja dissertação está em fase de redação, é então intitulada "Educação Ambiental e Participação na Agricultura caiçara: um estudo no bairro de Pedrinhas" (FAPESP no.00/6371-0). Para maiores detalhes ver Costa-Pinto, 2001.

${ }^{6}$ Ajutório é a reunião de moradores da comunidade para a realização de um trabalho coletivo, em que o beneficiário arca com as refeições dos que trabalham e se compromete a trabalhar posteriormente para aqueles que 0 ajudaram. Esta modalidade de trabalho coletivo de ajuda mútua é também conhecida como "troca de dia" (Costa Pinto, 2001).
} 


\section{RESULTADOS E DISCUSSÃO}

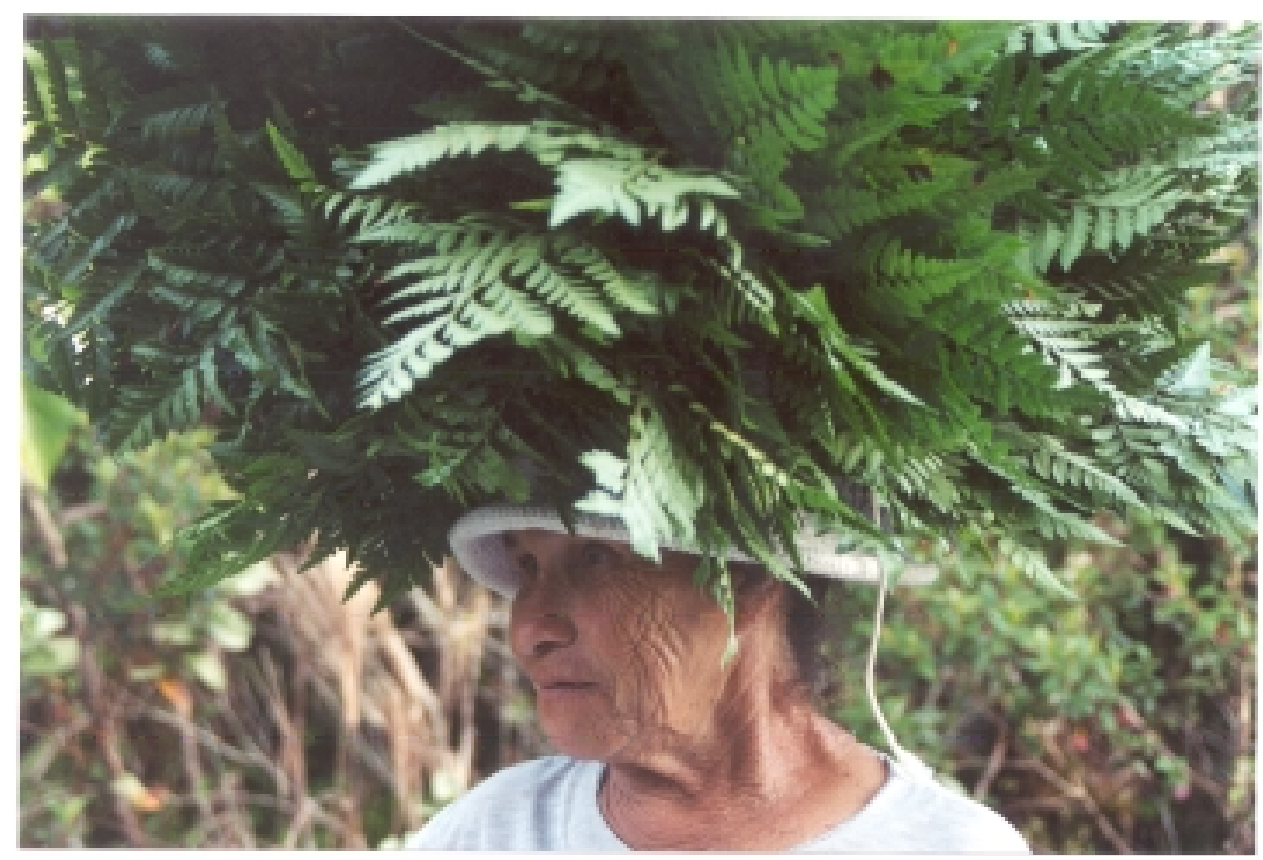

Foto: Alessandra B. Costa Pinto

Figura 7 - Extratora transportando a coleta do dia.

Neste capítulo serão apresentados os resultados obtidos durante a pesquisa sendo que, à medida que forem relatados, serão discutidos à luz do referencial teórico que a embasa. 


\subsection{Sobre a prática extrativista}

A prática extrativista foi considerada em dois momentos: o primeiro, antes do estabelecimento/regulamentação da APA, período em que não haviam restrições ao uso de recursos naturais locais, e um segundo momento após a implantação da mesma, ocasião em que os extratores passaram a uma condição de clandestinidade.

\subsubsection{A extração antes da regulamentação da APA}

A extração de samambaias (Rumoha adiantisformis), usada como ornamento para arranjos florais, vem ocorrendo desde o início do século $\mathrm{XX}$. Extratores com mais de 60 anos relatam que realizam esse tipo de atividade desde criança e afirmam que essa prática já ocorria antes disso:

"Desde criança, desde que eu comecei a ficar grande, desde doze anos e até assim desde os doze anos minha mãe me chamava pra tirar samambaias." ( Extratora 2)..

A extração de plantas ornamentais na região de restinga é uma atividade em expansão, a samambaia tem valor como planta ornamental pois mantém a sua coloração por semanas, sendo que atualmente tem sido usada por floriculturas do Vale do Ribeira e de grandes centros de São Paulo (Hanazaki, 2001).

Embora existam homens que façam a extração, no bairro de Pedrinhas onde concentrou-se a maior parte desta pesquisa, este tipo de atividade é realizado principalmente pelas mulheres, que têm entre 40 e 60 anos.

"Era o meio de ganhar dinheiro aqui, pescaria e samambaia, os homens na pesca e as mulheres na samambaia"( Extratora 1) 
As extratoras contatadas relatam que as samambaias extraídas eram comercializadas junto a atravessadores ${ }^{1}$ vindos de outras localidades - São Paulo, Santos, Iguape - e que a negociação sempre ocorreu diretamente com os extratores, ou seja, nunca houve intermediação via poder público.

"Vendia aqui, e quando não vendia aqui, a gente levava lá em Iguape, cortava as coisas aqui e levava pra lá para um tal de Seu Abílio, então cortava aqui as coisas e tinha que levar pra lá" (Extratora 2)

"Nós tirávamos e vendia para irmão do Geremias, ele ia de canoa, de porto em porto para buscar."(Extratora 3)

"...depois um outro rapaz pegou o trânsito do Rio Grande da Serra e ficou vindo comprá. Ele vinha duas vezes por semana comprá, e pagava" (Extratora 3).

Relatam que nem sempre os atravessadores efetuavam o pagamento no ato da compra e que, algumas vezes, sumiam e não pagavam mais.

"Alguns pagavam na hora, outros penduravam e teve gente que 0 comprador até ficou devendo pra eles né, deu calote." (Ex-extratora de samambaias)

A atividade extrativista sempre representou uma forma de complementaridade de renda, pois é comum entre os extratores a diversificação de atividades para obtenção dela.

No bairro de Pedrinhas a intensificação do turismo mostra-se como uma possibilidade significativa de obtenção de renda. No período de alta temporada

\footnotetext{
${ }^{1}$ Compradores vindos de outras localidades que faziam o escoamento e a comercialização junto a floriculturas.
} 
(entre outubro e março), os trabalhos domésticos nas casas de veraneio aparece como a opção mais lucrativa para as extratoras.

Após o estabelecimento da APA-IC, a extração de samambaias foi proibida, mesmo assim as extratoras continuaram com suas atividades, o que gerou uma situação de clandestinidade para elas.

\subsubsection{A atividade extrativista após a regulamentação da APA/IC}

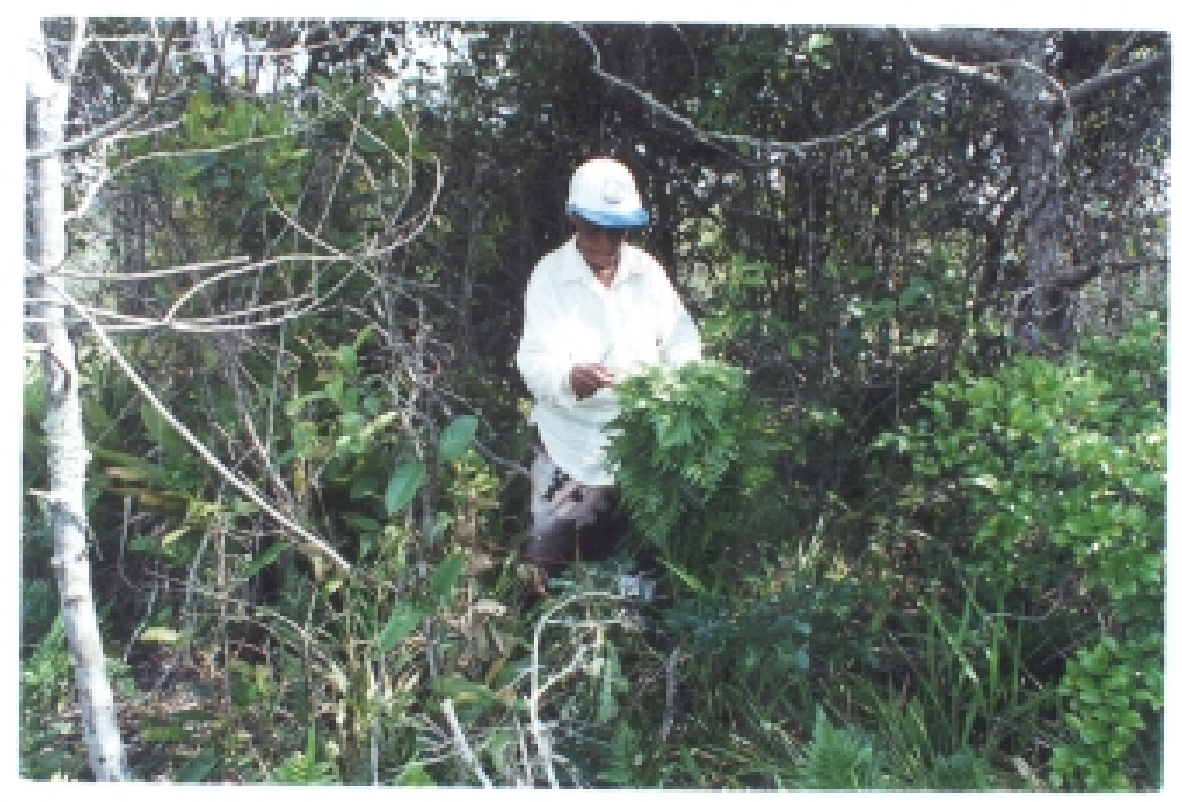

Figura 8 - Extratora em atividade.

Foto: Alessandra B. Costa Pinto

Logo após o estabelecimento da APA-IC, Carvalho (1999) relata que os produtos do extrativismo mais mencionados pela população caiçara eram a lenha e o piri, e que raramente se falava do palmito e da samambaia.

A autora argumenta que isto tenha ocorrido em função dos dois primeiros (lenha e piri) já fazerem parte de um passado remoto de utilização de recursos naturais, mas o palmito e especialmente a samambaia, ainda representavam um importante meio de obtenção de renda para muitas famílias. Porém, como as atividades extrativistas estavam legalmente proibidas naquele momento, embora 
ainda estivessem ocorrendo clandestinamente, as pessoas praticamente não falavam sobre o assunto.

Sobre aquele período as extratoras contam que:

“Pela lei mesmo era proibido ... não só essas plantas como qualquer outra planta, como a orquídea né, que elas foram bastante acabada, tiravam muitas orquídeas, até mesmo a gente tirava de vez em quando alguma, mas era proibido." (Ex-extratora)

"Depois ficou proibido porque aí veio o florestal, pelas lei do meio ambiente, essas coisas naquela época não tinha" (Extratora 2)

"Não, a gente pegava e saía né, mas era perigoso porque a gente ficava nessa, somos em bastante, porque se pegava vai pega todos né. Então começou, se só um tirasse (samambaias) mas era todos nós, porque não era só a gente que tirava, mas só que era tudo nós né," (Ex-extratora)

“...porque a gente precisava né, lógico que precisava, aí quebrava o galho da gente, pra comprar o pão..."(Ex-extratora)

As extratoras relatam que, neste período de proibição da extração, era necessário que as samambaias extraídas ficassem escondidas no "mato" em locais onde não pudessem ser encontradas e a comercialização com os atravessadores tinha que ocorrer "às escondidas".

Embora fosse do conhecimento de todos que o extrativismo continuasse ocorrendo, era necessário um cuidado especial, pois se um guarda florestal flagrasse as extratoras em atividade, ocasionaria problemas judiciais para elas. Isto de algum modo reduziu a extração e, consequentemente, o ganho das extratoras, porém tal proibição não foi suficiente para extinguir a prática. 
“(...) a gente andava escondido....porque a gente tinha medo do florestal das mata, então eles andavam, então se eles vissem a pessoa, ou com palmito com, qualquer coisa ai já tá vindo a lei, né." (Extratora 2).

"(...) porque a gente trabalhava escondido do florestal, se o florestal pegasse, além de tirar a samambaia, te multava." (Extratora 3 )

Os depoimentos acima demonstram a fragilidade do processo de implantação de UCs no Vale do Ribeira. A população local que antes do estabelecimento da APA utilizava os recursos naturais para obter renda, assistiu, do dia pra noite, as atividades que por anos fizeram parte de suas práticas cotidianas, virarem crime.

Em entrevista concedida à pesquisadora em abril de 1999, na ocasião em que a mesma desenvolveu um trabalho em grupo mencionado anteriormente, o então coordenador regional do IBAMA fala sobre as alternativas para a llha Comprida após o estabelecimento da APA.

“(...) os recursos tão aqui, então tem que fazer manejo, tem que investir em soluções técnicas, tem que aparelhar os órgãos, tem que trazer pessoas pra cá que de fato ajudem nesse trabalho, que é o trabalho que nós estamos fazendo aqui na llha Comprida, se municiando de consultores, porque tem determinadas coisas que nem os órgãos também não sabem..." (Coordenador regional do IBAMA - 11/04/1999)

O entrevistado insiste em resoluções técnicas como forma de buscar a sustentabilidade dos ecossistemas da llha e geração de renda também, o que já representa um avanço, mas em nenhum momento da sua fala foi considerada a importância da participação da população local para discutir os problemas ambientais locais e buscar conjuntamente com os técnicos os possíveis caminhos. 
Nota que os critérios utilizados para a implantação da APA-IC foram principalmente técnicos, ficando a população local excluída das discussões acerca do que contempla esta categoria de UC, ou seja, foi excluída dos processos participativos necessários para a implantação de uma lei desta natureza. Desta forma, torna-se extremamente difícil desencadear mecanismos que possam inserir esta população na discussão acerca da questão ambiental e que contribuam com seus "olhares" na busca da construção de uma sociedade mais democrática e consequentemente mais sustentável do ponto de vista sócioambiental .

Retomando Santos (1999) quando discute a construção de um novo paradigma para a ciência, neste caso é perfeitamente cabível a proposta da horizontalização dos saberes através do já mencionado conceito das "comunidades interpretativas" cujo objetivo principal é "(...) garantir e expandir a democraticidade" através da "(...) igualdade do acesso ao discurso argumentativo" pelo excluídos.

Diante do quadro que se instalou, ou seja, legislação proibitiva, necessidade de obtenção de recursos financeiros por parte dos extratores com conseqüente clandestinidade de atividades, a única possibilidade de reverter este quadro seria através da elaboração de um plano de manejo sustentável para que as samambaias pudessem ser manejadas adequadamente, e a organização dos extratores em torno de uma associação.

\subsection{Sobre o plano de manejo}

Em função da clandestinidade em que os extratores se encontravam e do que a atividade extrativista representava financeiramente para os extratores, a prefeitura local, em conversa com técnicos, iniciou o projeto para estabelecer o manejo de samambaias. A legalização da extração só seria possível se a espécie pudesse ser manejada adequadamente e para tanto seria necessário a realização de pesquisa científica que embasasse a prática de extração. 
A Prefeitura Municipal da llha Comprida estabeleceu parceria com a UFSC para a realização do projeto denominado Proposta de Estudo da Samambaia Silvestre (Rumohra adiantiformis) no Município de Ilha Comprida - SP (Conte, et al, 2000) $)^{2}$. O trabalho teve como finalidade estudar a biologia da espécie para que fosse estabelecido o manejo sustentado.

Este estudo ocorreu somente em função da exigência legal para a legalização da extração, pois no período que antecedeu a regulamentação da APA não havia uma preocupação do poder público em implantar um plano de manejo nem uma preocupação com a organização dos extratores em torno de uma associação.

Neste sentido, não se pode deixar de considerar que a imposição de estudos científicos determinados na legislação, como um dos requisitos para a legalização da extração de qualquer espécie da mata, além de contribuir com o aumento de conhecimentos acerca da samambaia, de certa maneira proporcionou também ao poder público a aquisição de um novo repertório em relação às vias legais para se pensar em outras espécies que potencialmente possam ser manejadas.

Um exemplo disso é o contrato estabelecido pela prefeitura com a UFSC (Anex01), desde junho de 2000, para a realização de estudo científico sobre o veludo $^{3}$. Essas espécies, assim como as samambaias, também têm valor ornamental e podem ser encontradas em floriculturas do Vale do Ribeira, São Paulo e Campinas. A extração destas espécies, inclusive, tem sido uma alternativa a mais de obtenção de renda. Embora a licença para extração do veludo ainda não tenha sido emitida, somente pelo fato da pesquisa científica já estar em andamento, possibilita a sua extração.

\footnotetext{
${ }^{2}$ Relatório entregue à prefeitura da llha Comprida por pesquisadores da UFSC

3 Várias espécies de Briófitas, incluindo Schlotheimia rugifolia, Campylopus lamellinervis, C. trachyblepharon, Syrrhopodon leprieeuirii, Sphagnum recurvum, S. capillifolium. (Hanazaki, 2001).
} 


\subsection{Sobre a formação da AMPIC}

A organização dos extratores em torno da AMPIC ocorreu inicialmente por parte da prefeitura, através de um levantamento do número de famílias que vinham fazendo a extração clandestinamente. Este levantamento aconteceu concomitantemente ao estudo científico da samambaia. O levantamento apontou que cerca de 70 famílias realizavam a extração e que essa prática representava uma importante complementação de renda para essas famílias.

No início de 1999, logo após a realização deste levantamento, foi oferecido pela prefeitura aos extratores um curso sobre associativismo e realizadas duas reuniões, em que estavam presentes os técnicos e funcionários da prefeitura, do IBAMA regional, vereadores e extratores. Nesta reunião "dividiu-se" a llha Comprida em cinco pontos de extração e para cada uma dessas cinco áreas foram eleitos dois representantes. Com relação a esses cinco pontos de extração, ficou definido que, de acordo com os locais de residência, o extrator estaria autorizado a coletar samambaias em apenas uma das cinco áreas estabelecidas. Portanto, um extrator que pertencesse à área cinco não poderia invadir a área quatro, respeitando desta forma os limites territoriais de extração.

Nas reuniões subsequentes, somente estiveram presentes os dez representantes dos cinco pontos de extração e os técnicos. Esta opção de trabalhar com apenas 10 extratores, de acordo com a prefeitura, ocorreu principalmente para facilitar as discussões acerca do estatuto e agilizar a formação de uma diretoria provisória para a associação.

De acordo com os relatos das extratoras, principalmente no que se refere ao estatuto, elas não se sentiram contempladas pelos representantes eleitos. Não ocorreu, por exemplo, uma discussão prévia entre os extratores de cada um dos cinco pontos com seus respectivos representantes, de maneira que aqueles que não estivessem presentes na reunião pudessem ter encaminhadas suas sugestões e desejos por meio dos primeiros. 
Portanto, as decisões tomadas foram somente comunicadas aos outros extratores posteriormente, logo perdeu-se a oportunidade de estabelecer um diálogo entre eles e, desta forma, desencadear processos reflexivos que pudessem contribuir rumo a uma educação política para a cidadania.

Cabe aqui recorrer a Benevides (1994, p.12) para pensar nos riscos da representação política no Brasil, que de certa maneira foi reproduzida nesta situação.

"Em termos mais gerais, a representação no Brasil permanece, efetivamente, uma representação no sentido teatral: a representação do poder diante do povo e não a representação do povo diante do poder. Nesse sentido, afasta-se da idéia de democracia como soberania popular".

A autora fala ainda que é necessário combinar representação e participação:

"Não resta dúvida de que a educação política - entendida como educação para a cidadania ativa - é o ponto nevrálgico da participação popular. Mas esta educação se processa na prática. Aprende-se a votar votando. (...) entender a participação popular como uma 'escola de cidadania' implica rejeitar aquela argumentação contrária que exagera as condições de apatia e despreparo absoluto do eleitorado, assim considerado incapaz, submisso, 'ineducável'. O que importa essencialmente é garantir ao povo a informação e a consolidação institucional de canais abertos para a participação - com pluralismo e com liberdade" (Benevides, 1994, p.10).

Após as reuniões em que apenas os representantes dos extratores e técnicos discutiram o estatuto e foram informados sobre a dinâmica de uma 
associação, outra reunião foi marcada para 12/04/1999 e nesta reunião foi realizada uma assembléia para fundação da AMPIC.

Em junho de 2000, é expedida a licença para a comercialização da samambaia e ocorrem as primeiras vendas legalizadas da história do município. (Anexo 2).

A partir desta data legalizou-se o Manejo Participativo de Samambaias Silvestres da llha Comprida, e, de acordo com dados da prefeitura, resultou numa redução de $80 \%$ na retirada ilegal de samambaias além de impedir a ação desenfreada dos atravessadores vindos de outras regiões. Portanto, do ponto de vista legal, a emissão da licença para o manejo foi extremamente positiva, as extratoras sentiram-se respaldadas, confiantes para realizar a extração, deixando para trás a condição humilhante de clandestinas.

"A gente trabalhava sem medo da polícia florestal agora. Eu lembro que já cheguei a me jogar no mato quando ouvia barulho. E olha que a gente estave trabalhando. Com essa lei, a gente pode trabalhar em paz". (Extratora 2).

"Sabe que era muito ruim trabalhar com medo de qualquer barulho. Lembro que eu tinha que ficar escondida no mato de medo. Sabe que se a polícia pegasse a gente poderia ir para a cadeia e o pior é que a gente não tinha dinheiro para pagar as multas. Agora está bom. Sempre gostei de trabalhar na mata, é a minha vida. E sem medo, em paz, então, é bem melhor. Sempre achei que não era justo trabalhar com medo da polícia." (Extratora 4) 


\subsubsection{Sobre os extratores associados}

A AMPIC conta com cerca de 130 extratores cadastrados, porém aproximadamente 55 vêm realizando extração regularmente. Através de dados fornecidos pela prefeitura foi possível traçar a seguinte tipologia destes extratores: E1: são aqueles que têm a extração como única fonte de renda F1: alta freqüência de extração (freqüência diária)

E2: são aqueles que têm outras formas de renda além da extração

F2: média freqüência (2-3 vezes/semana)

E3: são aqueles que extraem esporadicamente.

F3: baixa freqüência de extração (abaixo de 1 vez semana)

De acordo com esta tipologia, pode-se observar também, que a maioria dos extratores enquadram-se na categoria $\mathrm{E} 2$, ou seja, com média freqüência de extração, isto ocorre em função da já mencionada característica muito forte entre eles de diversificação de atividade de geração de renda.

\subsection{Como funciona a extração, o escoamento e a comercialização}

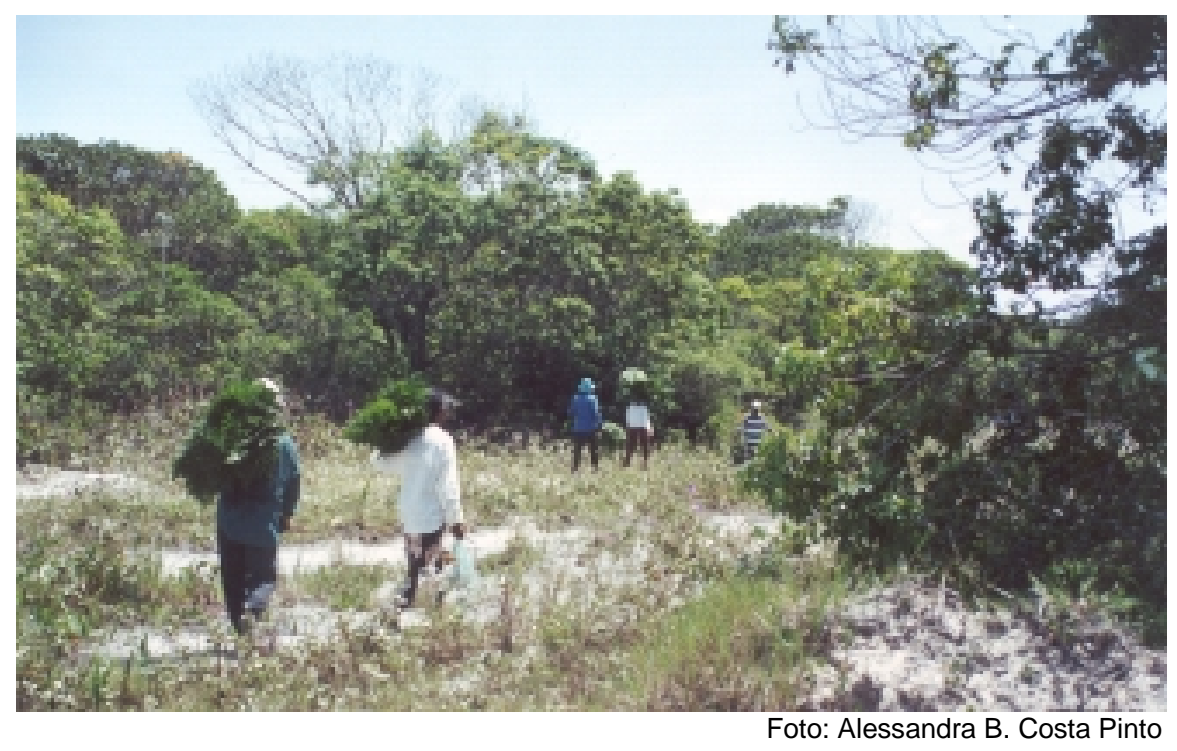

Figura 9 - Extratoras em atividade na restinga. 


\subsubsection{Das idas para o "mato"4}

Conforme mencionado anteriormente, foram estabelecidos, ao longo de toda Ilha Comprida, cinco pontos destinados à extração das samambaias e, portanto, não é autorizada a extração em outros pontos.

O acompanhamento da atividade extrativista do bairro de Pedrinhas, proporcionou observar que as extratoras deslocam-se em média $3,5 \mathrm{Km}$ até as áreas delimitadas para a extração.

A tarefa de extração é uma atividade árdua, pois é necessário que as extratoras estejam protegidas de insetos e do Sol. As roupas usadas (calça comprida, blusa de mangas longas, botas, boné) tornam a temperatura ainda mais alta em meio ao Sol. A comida geralmente é preparada bem cedinho, antes da saída para coleta, geralmente cada uma leva um tipo de alimento e no momento das refeições elas fazem trocas. Na maioria das vezes, quando vão comê-la, já está fria. Juntamente com os alimentos, as extratoras levam consigo garrafas de água, pois devido ao calor, é impossível não beber água durante todo o tempo.

Apesar de todas as dificuldades enfrentadas pelas extratoras, de acesso, as roupas quentes e a exposição ao Sol, a insetos e outros animais, além de terem que deixar almoço pronto em suas casas para os filhos e maridos, mesmo assim a extração mostra-se como uma atividade divertida para elas, pois nestes momentos elas compartilham os problemas cotidianos, conversam diferentes assuntos, cantam, rezam pedindo proteção divina antes de iniciarem a atividade, riem e brincam o tempo todo, tornando assim o trabalho muito mais prazeroso.

As extratoras nunca vão "ao mato" sozinhas, geralmente em grupos de três ou quatro mulheres. Nota-se que a afinidade estabelecida entre as amigas e o grau de parentesco acabam determinando a formação desse grupos como, por exemplo, cunhadas, irmãs, mãe e filha, tias e sobrinha etc.

\footnotetext{
${ }^{4}$ expressão usada pelas extratoras para designar o local onde realizam a extração
} 
As combinações acontecem no dia anterior, sendo que por volta das sete e meia/oito horas da manhã do dia seguinte partem do ponto combinado em direção às áreas de extração. É interessante um fato que as deixa mais tranqüilas, o de sempre haver um cachorro de alguma delas acompanhando toda a extração, relatam que os cachorros podem ajudar a identificar animais peçonhentos.

As extratoras mais jovens (por volta dos 40 anos) se aventuram mais que as senhoras mais velhas e geralmente são elas também quem escolhe por onde começar a extrair. Ficam muito atentas quando uma delas se afasta um pouco mais das outras ou entra um pouco mais na parte fechada da restinga, e imediatamente as demais começam ou a assobiar ou a dar gritinhos até que aquela responda. Dizem que nunca vão sozinhas porque caso aconteça algum acidente, tem no mínimo uma pessoa para ficar junto e outra para ir buscar ajuda.

A extração da samambaia é feita geralmente com uma faca bem afiada (Figura 8). As extratoras observam o tamanho e a coloração da samambaia para depois cortá-las. Vão segurando as folhas extraídas nas mãos e, quando atingem uma quantidade que já não podem segurar, deixam-nas em algum ponto e voltam para buscar depois. Geralmente elas escolhem um local que tenha um pouco de água e longe do sol, onde passe um pequeno córrego ou tenha uma poça, evitando desta forma que murchem.

Quando já extraíram uma quantidade que possam carregar até o bairro, fazem maços com as samambaias e sobre a cabeça transportam até em casa. (Figura 7)

Por volta de meio-dia, se for num dia bom de extração, já coletaram uma quantidade considerável e começam o caminho de volta. Geralmente aproveitam que estão com as roupas e o corpo sujos e começam a organizar as malas ${ }^{5}$ de samambaias.

\footnotetext{
${ }^{5}$ Mala - volume constituído de 6 maços de 10 folhas cada dispostos alternadamente em sentido contrário, atados por fita plástica.
} 
As malas ficavam em frente à casa de uma das extratoras, à espera do caminhão da prefeitura que duas vezes por semana passava por toda a llha recolhendo o que foi extraído para então comercializar em outras localidades.

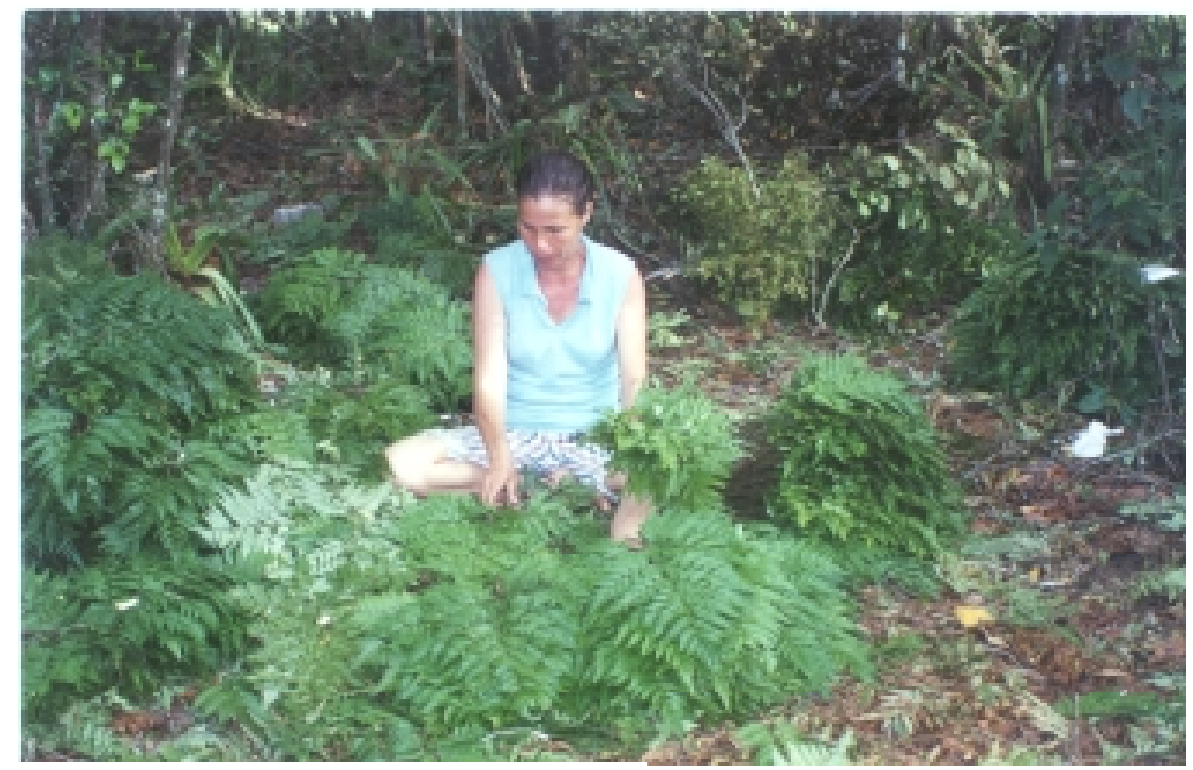

Figura 10 - "Arrumando as malas".

Foto: Vivian G. Oliveira

\subsubsection{Escoamento e Comercialização}

Dentre as regras estabelecidas pelo estatuto da associação, a venda das samambaias extraídas só poderia ser feita exclusivamente à prefeitura que, portadora da licença emitida pelo IBAMA, se encarregava do escoamento e comercialização.

Alguns depoimentos demonstram que 0 desaparecimento dos atravessadores, com conseqüente obrigatoriedade da comercialização junto à prefeitura, foi uma maneira de controlar a quantidade de samambaias extraídas. A prefeitura justifica-se dizendo que as pessoas de fora da Ilha Comprida podem obter ganhos com os recursos naturais extraídos do município, e porque não a própria associação otimizar esse ganhos?

A prefeitura disponibilizava um caminhão que passava duas vezes por semana ao longo de toda llha buscando as malas de samambaias, que eram 
transportadas e posteriormente comercializadas junto a floriculturas do Vale do Ribeira, São Paulo e Campinas.

O pagamento dos extratores era efetuado no momento da entrega das malas. Para cada mala era pago $R \$ 0,80$ (ainda o mesmo valor até janeiro/2002) aos extratores e na comercialização era vendida a $R \$ 1,30$ no mercado. A diferença arrecadada era revertida à associação para custear os gastos, principalmente de combustível para o escoamento, e também para a remuneração dos extratores no período do defeso ${ }^{6}$.

Durante o ano, a extração ocorre somente por dez meses. O estatuto prevê que dois meses do ano deva haver um período para o defeso. Esse acordo baseou-se nos estudos realizados pelos pesquisadores da UFSC, que apontaram a média de tempo de regeneração da espécie de 39,5 dias.

Os meses de janeiro e fevereiro foram eleitos pelos extratores para 0 defeso. A escolha destes meses ocorreu principalmente em função do alto fluxo de turistas para a llha Comprida nesta época do ano, já que, conforme discutido anteriormente, as atividades relacionadas ao turismo representam uma renda significativa para o orçamento dos extratores. De acordo com a prefeitura e os técnicos, a escolha dos meses de janeiro e fevereiro foi oportuna do ponto de vista comercial, porque durante esses meses, conforme pesquisa de mercado realizada, ocorre uma estagnação econômica das floriculturas. Mas de acordo com o depoimento de um dos extratores, a melhor época do ano para o defeso seria agosto e setembro pois o período é marcado por baixa intensidade de chuvas e as samambaias ficam mais escassas.

Gonçalves (2001, p. 135-136) discutindo a questão do salário-defeso, dos pescadores de Mundaú e Manguaba, em Maceió, nos fala que:

"A proposta do salário-defeso é extremamente interessante porque supera a falsa dicotomia, verdadeira armadilha ideológica do pensamento

\footnotetext{
${ }^{6} \mathrm{O}$ defeso refere-se ao período em que as samambaias não deverão ser extraídas, respeitando o tempo necessário à sua regeneração e no caso da AMPIC, escolheu-se os meses de janeiro e fevereiro.
} 
ocidental, que separa a natureza da sociedade. (...) é uma idéia originalíssima na medida em que por meio dela, a sociedade preserva o que não é o homem - a lagoa e seus peixes - e, ao mesmo tempo, vê preservados os pescadores e sua cultura. E, com um acréscimo, sem dúvida, que é o de levar em conta o conhecimento do pescador como um conhecimento válido, o que é um avanço no sentido de considerá-lo cidadão e, portanto, como um portador de direitos e, mais do que isso, protagonista de direito. Nesta proposta não se tem de escolher entre a natureza ou a cultura, ou entre o homem, de um lado, ou a natureza de outro."

Nos meses do defeso, os extratores recebem uma quantia referente à média de ganhos obtida durante os dez meses em que ocorre a extração. A garantia de remuneração e a não disponibilização do caminhão para buscar as samambaias eram fatores importantes para que o defeso fosse respeitado.

A prefeitura, visando ampliar a comercialização, adquiriu um box no CEASA/Campinas onde as samambaias eram vendidas e, esperando obter maiores informações sobre o mercado de consumo, vislumbrava uma comercialização mais intensiva, inclusive pensando no mercado da Holambra. Além disso vinha buscando também ampliar a produção através do estabelecimento de novas parcerias junto a outros municípios da região (Iguape e Cananéia).

Além da remuneração durante o período de defeso, o estatuto prevê também um $13^{\circ}$ salário no mês de dezembro de cada ano, cujo valor também refere-se à média anual de extração. No final do ano 2000, ocorreu o primeiro pagamento do $13^{\circ}$ salário.

Alguns extratores contatados não concordaram com os valores recebidos, dizendo que não correspondia à média anual. Esses valores nunca foram discutidos e nem avaliados coletivamente, não houve também uma apresentação da contabilidade anual aos associados da AMPIC. 
Essa é uma postura que parece favorecer uma relação empregador/empregado, ou seja, reafirma uma relação de dependência dos extratores para com a prefeitura. A noção de associativismo poderia ser intensificada nessa oportunidade, mas não foi o que ocorreu.

Este fato reforça uma relação paternalista, muito comum na nossa sociedade, em que o poder público ao invés de se propor a fazer um trabalho emancipatório, acaba reafirmando uma postura assistencialista em relação aos extratores, uma vez que não são discutidos pontos fundamentais que seriam propícios para potencializar processos educativos.

\subsection{Das reuniões}

Nas reuniões, geralmente estavam presentes o prefeito, os técnicos responsáveis pelo manejo, vários vereadores e os extratores.

$\mathrm{Na}$ composição da mesa, pode-se notar que era sempre composta por políticos, técnicos e nunca houve um representante dos extratores.

"Antes da gente começar, gostaria de chamar o vice-prefeito da llha Comprida, o presidente da câmara, o presidente do IBAMA e chamar também os vereadores aqui presentes (...)". (Engenheiro Agrônomo

Sobre a direção dos trabalhos durante as reuniões, foi possível identificar uma postura que, de certa forma, inibia a manifestação dos extratores.

"A primeira coisa a perguntar é: quem vocês escolhem para dirigir os trabalhos? Eu me proporia a dirigir esse trabalhos e se o plenário assim 0 aceitar, nós podemos dar início aos trabalhos dessa assembléia geral."(Prefeito da Ilha Comprida) 
Quem dos extratores se manifestaria contrariamente a esta fala do prefeito?

Quando perguntados sobre o que se discutia nas reuniões.

"E quando tem as reuniões lá da associação, o que se discute?" (pesquisadora)

"Fala pra gente obedecer as ordens, se não obedecer ordem..." (Extratora 2)

"Mas que ordem?" (pesquisadora)

"As ordens que ele fala pra gente, olha só, que nem a samambaia, a samambaia tem um tempo pra tirar, como agora, parou, a samambaia, nóis estamos no Fofão. O tamanho tem que ser grande, a samambaia está pequena, então não pode botar a mão." (Extratora 2).

As frases transcritas acima, demonstram um pouco da visão que os extratores têm da parceria junto à prefeitura, ou seja, é aquele que estabelece as regras que devem ser cumpridas e não um parceiro que possibilite um diálogo. Portanto não se sentem parte do processo.

Compartilhando com Benevides (1984) quando diz:

"É evidente que uma educação política não pode ser entendida numa via única - só do Estado para o povo. Mas, sim, pela exigência da pluralidade de agentes políticos (...) A educação política, num contexto democrático, supõe que os próprios interessados se transformem em sujeitos políticos." (Benevides. 1994:14) 


\subsection{Identificando conflitos}

Puderam ser identificados durante o processo os seguintes tipos de conflitos:

$\mathrm{C}_{1}$ : Extratores $\mathrm{X}$ Extratores

Em 25/11/00 houve uma reunião entre os extratores e os técnicos da prefeitura responsáveis, em que foi discutido o novo estatuto da associação, estabelecendo-se novas regras.

O principal foco da discussão do novo estatuto, segundo os extratores entrevistados, foi relativo aos pontos (ou territórios) de extração. Um conflito explícito refere-se à invasão de grupos que pertencem a um determinado ponto de extração e acabam se deslocando para áreas destinadas a outros extratores. Há inclusive extratores que afirmam que o próprio caminhão da Prefeitura favorecia o deslocamento de alguns extratores para outras áreas que não a deles.

De acordo com o estatuto da AMPIC ficou estabelecido que Sobre essa última regra citada, observa-se que há um conflito explícito na fala dos extratores, pois alguns extratores invadem áreas que pelo estatuto são destinadas a outros extratores. Os extratores reclamam ainda que esse fato já foi relatado para a prefeitura em algumas oportunidades e a postura é que em nome da "produção" essa violação do estatuto é legitimada. Essa legitimação por parte do poder público, abre precedentes para o não comprimento de outras regras previamente estabelecidas.

Além disso, de acordo com depoimento de alguns extratores, o presidente da associação não está se dedicando como os demais associados gostariam, porém ficou estabelecido que só fariam uma nova votação quando acabasse o mandato ou seja, o presidente não seria substituído mesmo estando totalmente ausente. O mandato acabou em março de 2001 e somente em (dez/2001) é que foi eleita uma nova diretoria. O presidente da AMPIC foi reeleito e a diretoria também se manteve quase a mesma. 


\section{$\mathrm{C}_{2}$ : Extratores X Prefeitura}

Ainda sobre a questão da invasão de áreas, os extratores relataram que esse conflito foi colocado em várias reuniões mas que não foi feito nada para solucioná-lo.

"Todas as reuniões, é falado a mesma coisa. A gente briga pra manter aquele trecho de trabalho da pessoa, mas eles não querem respeitar." (Extratora 3)

"Mas a prefeitura fala o quê?" (pesquisadora)

"O prefeito falou assim: " - Já que o pessoal daqui não está tirando é pro pessoal invadir e tirar." E é um erro né!" (Extratora 3).

“... é falado sobre a área, só que eles acham que nós não temos razão, acha que nós não olha a nossa área, então é difícil pra gente. Até mesmo eles próprios trouxeram pessoal para tirar samambaia daqui. Vem 0 caminhão, leva embora, como é que a gente faz?, nas reuniões a gente foi falar com o prefeito" (Extratora 1)

"E qual a posição dele?" (pesquisadora)

"Ele fala que manda, porque o povo daqui não tira, não tem nada a ver." (Extratora 1)

O prefeito e outros envolvidos diretamente com a comercialização justificam essa postura em nome do aumento de produção. $O$ mercado exige principalmente qualidade e freqüência do volume, e devido a diversificação de atividades de geração de renda por parte dos extratores, a freqüência de volume é que dá garantia da comercialização. Se a garantia do volume não for dada, os compradores acabam negociando com outros fornecedores.

O compromisso assumido pelo poder local com a compra de um box no Ceasa/Campinas antes mesmo de conhecer um pouco mais a dinâmica do mercado, acabou gerando uma situação insustentável. Os gastos com transporte 
da samambaias começaram a superar os ganhos e consequentemente fez com que o poder público iniciasse uma pressão sobre os extratores insistindo no aumento de produção.. No decorrer dos dois anos, a prefeitura alega a baixa produção como a vilã da história e nas últimas reuniões o assunto em pauta foi esse.

Neste caso, a lógica que domina o discurso político é uma lógica mercadológica, e a imposição de tal lógica não foi assimilada pelos extratores.

O controle da extração efetuado pela prefeitura proporcionava conhecer a média de ganhos mensais realizada pelo extrator. A diferença arrecadada pela prefeitura na comercialização das samambaias (pagavam $\$ 0,80$ por mala e vendia a $\$ 1,30$ ) é que proporcionava o pagamento referentes aos meses do defeso, além do $13^{\circ}$ terceiro salário.

Um outro agravante é com relação às áreas estabelecidas pelo estatuto. $\mathrm{A}$ prefeitura parece reforçar o conflito entre os extratores, legitimando a invasão de áreas em função do aumento da produção.

\subsection{Como está funcionando hoje}

Recentemente (outubro/2001), houve rompimento da parceria entre a AMPIC e a prefeitura, em função da baixa produtividade. A prefeitura retirou os funcionários que estavam trabalhando junto à associação e ofereceu o veículo para os associados continuarem recolhendo as samambaias ao longo da llha. Os extratores optaram em não ficar com o caminhão por medo de não conseguirem arcar com as despesas de manutenção. Isto implicaria no custo de combustível, pagamento de um motorista além da manutenção mecânica dele.

A saída encontrada pelos extratores, até o momento do rompimento da parceria (março de 2002), foi cobrar uma tarifa de $\$ 5,0$ de cada extrator por mês para complementar o salário defeso e para a custear a manutenção da associação . 
Optaram então por retomar a comercialização direta do extrator com os atravessadores iniciando assim um novo momento da associação. Um fato importante é que a partir de março de 2002, a diretoria da AMPIC vai realizar a contabilidade do movimento da AMPIC.

Neste momento, a participação da prefeitura junto a AMPIC está ocorrendo unicamente através da emissão da licença de comercialização aos extratores, pois conforme descrito anteriormente, a licença foi concedida à prefeitura e não à AMPIC. 


\section{CONSIDERAÇÕES FINAIS}

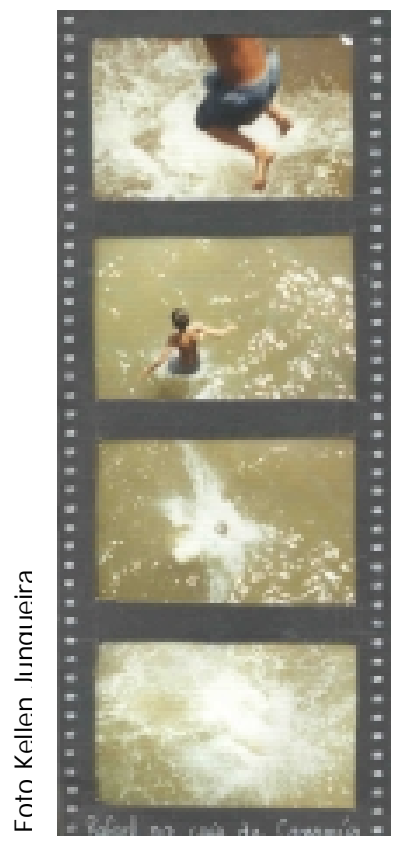

Mergulho

com o corpo solto no universo

A gravidade orienta o vôo

Não há limites entre céu e mar

bate o vento no coração

a fluidez da água

suaviza o lançamento voluptuoso deslizando para o centro da terra

o retorno guarda a lembrança do desconhecido que há de manter-se em mistério que há de ser sempre explorado!

Kellen Junqueira

Figura 11 - Garoto mergulhando no Mar Pequeno.

$\mathrm{Na}$ maioria das vezes lida-se muito bem com aquilo com que se tem prática, ou seja, que são familiares às reflexões do dia a dia. Isso não quer dizer que se é incapazes de desenvolver novas habilidades. A falta de "prática" de participação, não significa que o sujeito esteja impossibilitado de adquirir novos repertórios que possam propiciar uma cultura participativa.

A percepção que se tem da parceria estabelecida entre a AMPIC e a Prefeitura local, é de que a falta de prática participativa vem ocorrendo tanto por parte dos extratores quanto da prefeitura. A prefeitura conduziu todo o processo de formação da Associação e do estabelecimento do plano de manejo, porém não 
implementou propostas que facilitassem um envolvimento maior por parte dos associados, que pudessem gerar oportunidades de manifestações não apenas informativas com relação as suas práticas mas também de seus desejos e necessidades.

A maneira como os trabalhos foram conduzidos, demonstram que o poder público não implementou um adequado tratamento de questões educativas muito importantes para desencadear processos emancipatórios, tornando assim, os sujeitos autores de suas ações.

Sueli Furlan (2000), em sua leitura de Santos (1987:99) diz:

"Está presente no discurso dos governantes a questão dos direitos sociais e da cidadania. Em nosso país se fala no reaprendizado da cidadania pela participação, liberdade de expressão, direitos civis, etc. (Santos, 1987:99). Mas numa sociedade onde o modelo cívico não parte dessa "pedagogia", e sim da supremacia econômica, do individualismo, do consumismo, da exclusão social, da competição cada vez maior, em detrimento das outras dimensões socio-ambientais, tais como o respeito a pluralidade cultural, a ecologia, a ética, a vida humana, etc. essa aprendizagem fica muito distante".

$\mathrm{Na}$ condução dos trabalhos junto a AMPIC, notam-se alguns detalhes que parecem insignificantes, mas que acabam por reiterar uma postura de dominação. A composição da mesa apenas por políticos (vereadores, vice-prefeito) e técnicos (engenheiros agrônomos responsáveis pelo manejo, presidente do IBAMA etc.) e nenhum representante dos extratores. As discussões da reunião caminham com colocações somente por parte dos políticos e técnicos e a ênfase é dada com relação à produção, ou seja, insistem no aumento de produção e atrelam este fato ao sucesso dos trabalhos. 
A prefeitura coloca que a extração deve ocorrer com uma certa intensidade para garantir o volume para comercialização. Citam várias vezes que o não comprometimento dos extratores com o volume e regularidade das extrações compromete também a viabilidade das atividades. Colocam que esse problema de baixa produção ocorre porque alguns extratores só fazem a extração quando estão com "vontade" e que a inconstância na produção dificulta a garantia de comercialização.

Esta lógica está pautada numa visão mercadológica e não nas necessidades e dificuldades encontradas pelos extratores. A "participação" nesse caso está única e exclusivamente condicionada ao aumento de produção. O extrator participativo é aquele que reproduz aquilo que the é imposto, e aquele que assim não atua, está em desarmonia com os demais.

Sobre uma lógica capitalista, mercadológica, o investimento em propostas pedagógicas/educativas que contribuam com o processo emancipatório dos sujeitos, que busquem o estabelecimento de relações democráticas parecem "perda de tempo" e o investimento nestes setores pelo prisma econômico mostram-se desnecessários.

Gonçalves nos fala que baseado na lógica econômica:

"Tudo deve ser prático e a democracia é sempre muito demorada, implica o diálogo, ouvir o outro e, deste modo, tudo isso parece 'perda de tempo', porque a produtividade é uma questão de quanto produzimos numa determinada unidade de tempo. A política é lenta quando olhada a partir de uma racionalidade econômica. Assim a lógica econômica tende para a tirania e não para a democracia" (Gonçalves, 2000, p. 64).

Isso nos remete mais uma vez à questão de prática participativa tanto por todos os sujeitos nela envolvidos. A imposição de uma lógica que não faz parte do cotidiano dos envolvidos dificulta a construção do sentido coletivo e participativo 
dos extratores. Há uma auto-estima a ser trabalhada, há um fazer sentido e estes pontos dizem respeito à educação.

Os processos educativos somente ocorrem à medida que surgem oportunidades de manifestações. A imposição de uma lógica diferente daquela que geralmente não se está acostumado, não ocorre quando forjada, se dá através de processos de diálogo e reflexão sobre a prática de suas atividades. $\mathrm{Na}$ busca do estabelecimento da cidadania.

Segundo Furlan (2000)

"A cidadania brasileira, em sentido amplo, procura nascer através de alguns processos participativos fragmentários, muitas vezes cooptados por interesses maiores, conduzidos por interesses da minoria, impregnado de ideologias que vedam os olhos dos cidadãos, retirando-lhes os alicerces da construção de sua autonomia para a prática democrática. Penso que convocar pessoas à participação ou para a tomada de decisão, sem este construto, é colocá-las submissas diante das forças "dos reis". A capacidade de poder ver, analisar, refletir, escolher...enfim participar, se aprende. Aprende-se com oportunidades e experiências participativas."

Neste sentido recorre-se mais uma vez a Freire (1975) quando diz:

"Conhecer não é o ato através do qual um sujeito transformado em objeto, recebe dócil e passivamente os conteúdos que outro lhe dá ou lhe impõe. O conhecimento pelo contrário, exige uma presença curiosa do sujeito em face do mundo. Requer sua ação transformadora sobre a realidade. Demanda uma busca constante. Implica invenção e reinvenção" (Freire,1975, p.) 
Faz-se necessário o envolvimento direto de pessoas da associação na tomada de decisões, bem como, na prestação de contas, no transporte e comercialização das samambaias, no entendimento de como se comporta o mercado. Enfim, se a os extratores fossem ouvidos, se construíssem as regras coletivamente e participassem não apenas de decisões objetivas, mas explicitando também sua subjetividade, seria uma oportunidade para que, além de adquirirem novos repertórios, se sentissem também parte do processo; e nesse sentindo, o envolvimento poderia ser potencializado.

Discussões técnicas são muito importantes para a tomada de decisões num projeto de manejo sustentável, mas um trabalho educativo se mostra imprescindível na busca de uma postura coletiva democrática e consequentemente para o sucesso do próprio manejo.

As entrevistas realizadas junto aos extratores demonstram que é cultural a diversificação dos trabalhos e que a freqüência de extração e a regularidade do volume realmente ficam comprometida.

Emergem algumas questões: Como conciliar as atividades dos extratores com os objetivos do manejo? Em que medida essa diversificação de atividades dos extratores contribuem para a sustentabilidade? E para a felicidade deles? Eles existem como grupo? Como os técnicos e políticos envolvidos nestes projetos podem contribuir com esses processos educativos? Qual o papel da universidade?

O diálogo com Freire, 1975 diz que:

"Não é possível entender as relações dos homens com a natureza, sem estudar os condicionamentos histórico-culturais a que estão submetidos suas formas de atuar." (Freire, 1975)

De nada adiante tentar substituir uma forma de conhecimento, é preciso que os atores atuem e neste sentido: 
"Atuando, transforma; transformando, cria uma realidade que, por sua vez envolvendo-o, condiciona sua forma de atuar.

Não dá para dicotomizar o homem do mundo, pois que não existe um sem o outro

(...) a ação educadora deve ser a de comunicação se quiser chegar ao homem, não ao ser abstrato, mas ao ser concreto inserido numa realidade histórica" (Freire, 1975).

Diante das colocações ao longo desta dissertação, propõe-se que o poder público invista sim em cursos técnicos de capacitação dos extratores, se aproveitando inclusive de recursos humanos que já pertençam ao quadro de funcionários e estabelecendo por exemplo parcerias com a universidade, ONGs, buscando incrementar o repertório técnicos destes extratores.

Todavia, para se pensar caminhos que realmente possam contribuir com a sustentabilidade ambiental, social e democrática, esta dissertação sem esgotar as possibilidades, propõe que o poder público lance mão de estratégias que realmente contribuam para o incremento e para a aquisição de novos repertórios, não apenas técnico mas também que tenham potencialidade de incrementar uma "cultura participativa".

Segue abaixo as etapas da proposta de intervenção que foi pensada durante a pesquisa e que devido as circunstâncias da parceria da AMPIC com o poder público, conforme descrito anteriormente, não foi possível ser realizada durante a elaboração desta dissertação mas que será desenvolvida ainda no primeiro semestre deste ano. 


\subsection{Etapas da intervenção}

A reunião teria duração de 3 horas, e a disposição dos participantes em círculo.

Num primeiro momento, seriam explicitados quais os objetivos a serem alcançados pela reunião e levantas as pendências da última reunião.

1 a parte - Apresentação - (duração de 30 minutos)

Nesta primeira etapa, seria feito uma rodada de apresentações buscando promover um clima de descontração entre os participantes e ao mesmo tempo proporcionar uma aproximação entre eles. Nesta dinâmica, cada extrator se identificaria dizendo o nome e o local de origem. Para esta dinâmica, cada participante utilizaria algum objeto que julgasse caracterizá-lo.

$2^{\text {a }}$ parte - Início da avaliação - (45 minutos)

Para iniciar a avaliação dos dois anos de associação e implantação do manejo participativo, seria usado um barquinho de madeira (levado pelas mediadoras) que simbolizaria a associação, e levantadas as seguintes questões: O que ajudou o barco a andar? E o que dificultou o barco a andar?. O barquinho passaria pela mão de todos os participantes e cada um expressaria a sua opinião sobre o andamento da associação. Após essa etapa, os extratores seriam divididos em grupos (de preferência colocando extratores de diferentes áreas para discutirem juntos) e cada grupo elaboraria um cartaz com os principais problemas identificados.

Após essa reflexão em que o barquinho serviria de metáfora para avaliar o desempenho da Associação e da efetividade do manejo, haveria um intervalo para lanche. Esse intervalo também pode proporcionar uma maior interação entre os extratores fora do momento oficial da reunião. (30 minutos de intervalo)

3믈 parte - Apresentação dos grupos - (duração de 45 minutos)

Nesta etapa cada grupo apresentaria o seu cartaz e à medida que um grupo observa o outro, os problemas comuns vão sendo identificados e os problemas específicos de cada área de extração também. Após esta 
apresentação, seria levantada a seguinte questão: O que é preciso melhorar? Quais são os pontos prioritários a serem encaminhados? Após o levantamento destas questões, elaboraria-se um cartaz único com os problemas recorrentes elencados pelos extratores e os caminhos para buscar a resolução dos mesmos.

$4^{\mathrm{a}}$ parte - Dinâmica de fechamento - (duração de 20 minutos)

Nesta dinâmica, duas pessoas deixam a sala e os demais elaboraram um desenho coletivamente, que passa a representar o projeto de manejo coletivo. Depois da elaboração do desenho, as duas pessoas que não participaram do processo de elaboração voltam para a sala. O desenho é mostrado apenas para um dos dois e este terá que enunciá-lo para o outro desenhar. A pessoa que desenha não vê o desenho original, elaborado pelo grupo, e então de acordo com a comunicação de seu colega vai tentando elaborar o desenho.No final, é muito provável que o desenho elaborado seja muito diferente do original o que proporciona um gancho para discutir a importância da participação de todos quando se elabora um projeto coletivamente. A importância de se sentir parte do processo e de ver seus desejos e opiniões contemplados no projeto. As diferentes interpretações de uma mesma situação.

Após esse fechamento, seria identificada por parte dos participantes a necessidade da realização de uma próxima reunião para encaminhar outras soluções para os problemas identificados e a distribuição de tarefas. 
ANEXOS 


\title{
Anexo A - Licença para escoamento das samambaias.
}

\author{
Via Iriti....t.
}

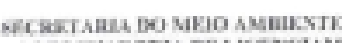

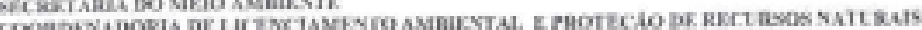

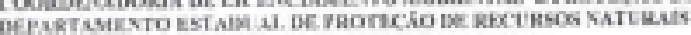

\section{AUTORIZACÃO PARA ESCOAMENTO DE PRODUTOS E SUB-PRODUTOS ORIGINARIOS DA FLORESTA}

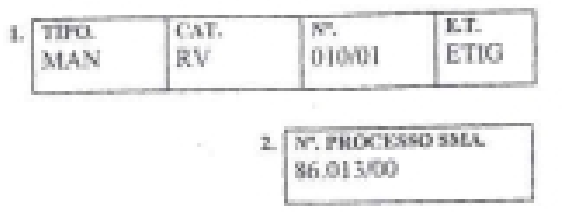

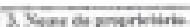

PREFETURA MUNICIPAL, DE ILIIA COMPRIDA-AMPIC

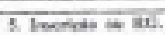
XXXXXXXXXXXXX

\section{Geado diat}

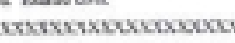

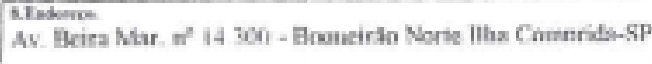
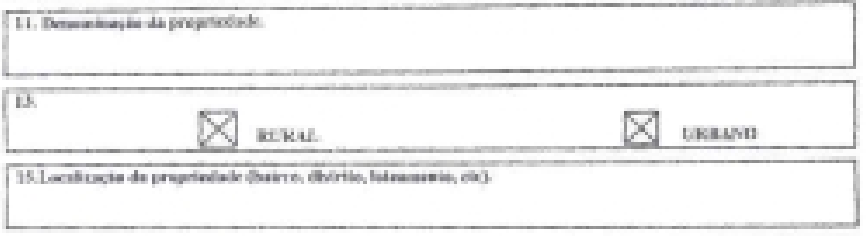

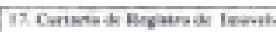

Comarca de lgupe

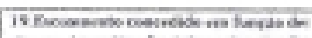

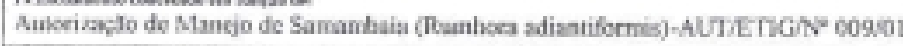

\begin{tabular}{|c|c|c|c|c|}
\hline 15 & byomit Whatsel & Quribiti & Yotanis] & 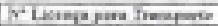 \\
\hline \multicolumn{5}{|l|}{ Yhibes in frien } \\
\hline \multicolumn{5}{|l|}{$\operatorname{lom}$} \\
\hline imp & & & & \\
\hline \multicolumn{5}{|l|}{ inds } \\
\hline \multicolumn{5}{|l|}{ Coos } \\
\hline \multicolumn{5}{|l|}{ bint: } \\
\hline \multicolumn{5}{|l|}{ 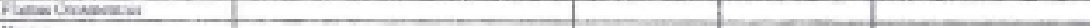 } \\
\hline Xeven & & & & \\
\hline Thens & Savuriea & 75012 Kefles & & \\
\hline
\end{tabular}

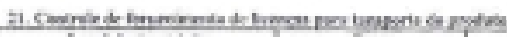

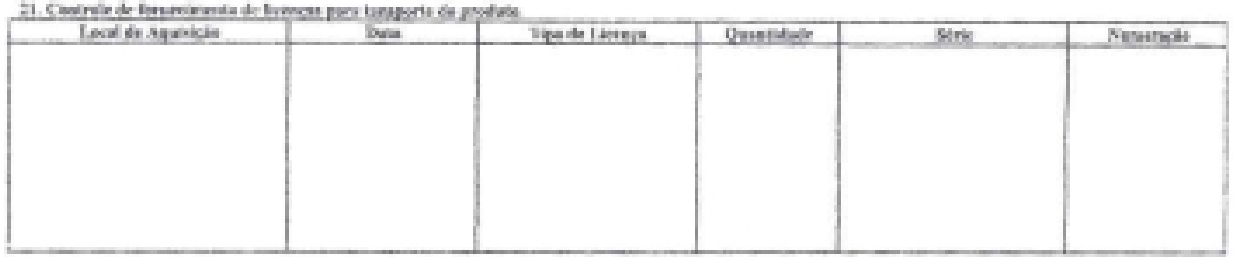

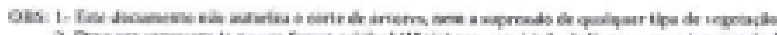

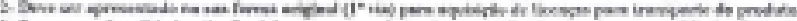

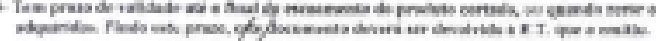

\begin{tabular}{|c|c|}
\hline 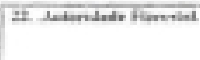 & 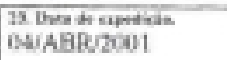 \\
\hline I6 antions & 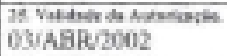 \\
\hline
\end{tabular}

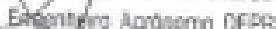

Cres D6524601420 


$$
\text { ia lín- - - }
$$

SECRETARIA DO MEIO AMBIENTE

COORDENADORIA DE LICENCIAMENTO AMBIENTAL E PROTECÃO DE RECLRSOS NATURAS DEPARTAMENTO ESTADUAI. DE PROTECÃO DE RECURSOS NATURAS

\section{AUTORIZAÇÃo}

\begin{tabular}{l}
\begin{tabular}{|l|l|l|l|}
\hline $\begin{array}{l}\text { TIPO. } \\
\text { MAN }\end{array}$ & $\begin{array}{l}\text { CAT. } \\
\text { RV }\end{array}$ & $\begin{array}{l}N^{\circ} . \\
009 / 01\end{array}$ & $\begin{array}{l}\text { E.T. } \\
\text { ETIG }\end{array}$ \\
\hline
\end{tabular} \\
\hline
\end{tabular}

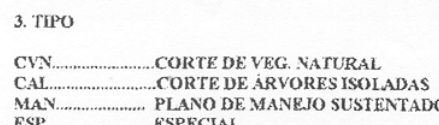

7. Denoninacdo da propriedade.
APA-Ilha Comprida

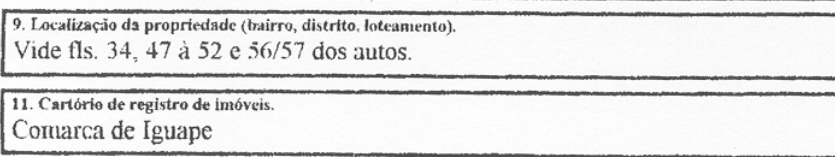

Comarca de Iguape

\section{Finalidade.}

Extração/Manejo de Samambaia (Rumohra adiantiformis)

\begin{tabular}{l}
\hline 6.CIC ou CGC. \\
\hline 8. Area total da propriedade. \\
$304,00 \mathrm{ha}$ \\
\hline
\end{tabular}

15. Autorizaça de Corte de Vegetaçio Natural.

\begin{tabular}{|c|c|c|c|c|}
\hline $\begin{array}{c}\text { 15. Autorizaça de Corte de Vigetacio Natural } \\
\text { Tipo vegetaçio }\end{array}$ & Estagio de sucessãu & $\begin{array}{c}\text { Area Autorizada } \\
\text { (em ha) }\end{array}$ & $\begin{array}{c}\text { Quantidade } \\
\text { Autorizada }\end{array}$ & $\begin{array}{c}\text { Volume } \\
\text { Lenhoso }\left(\mathrm{s}^{3}\right)\end{array}$ \\
\hline Restinga-Res.CONAMA-7/96-SAMAMBAIA & XXXXXXXX & 253,11 ha & 7.593 .260 & FOLHAS \\
\hline & & & & \\
\hline
\end{tabular}

\begin{tabular}{|c|c|c|c|c|c|}
\hline Discriminą̧ão & Tipo Vegeturão & Estigio & $\begin{array}{l}\text { Area Autorizada } \\
\text { (em lia) }\end{array}$ & $\begin{array}{l}\text { Quantidade } \\
\text { Autorizada * }\end{array}$ & $\begin{array}{c}\text { Volume } \\
\text { Lenhoso }\left(\mathrm{m}^{3}\right)\end{array}$ \\
\hline \multirow{2}{*}{\multicolumn{6}{|c|}{\begin{tabular}{|l} 
APP (cum Vegetą̧̧o Natural) \\
APP (scm Vegetação Natural)
\end{tabular}}} \\
\hline & & & & & \\
\hline \multicolumn{6}{|l|}{ Retserva Legis-Mancjo } \\
\hline & & & & & \\
\hline
\end{tabular}

\begin{tabular}{|l|c|}
\hline 17. Locais näo paassiveis de corte dentro da propriedade. & Area (ha) \\
\hline Presetvaço Permanente - (Discriminar) & \\
\hline Resenva Legal & \\
\hline Area Remaanescente & \\
\hline
\end{tabular}

18. Area Complementar(area ocupada)

19. Observaçdes.

Esta autorização esta de acordo com o Decreto Federal n $n^{\circ} 750 / 93$ e demais normas pertinentes, com destaque para Portaria DEPRN n ${ }^{\circ} 052 / 98$, tratando-se de manejo participativo e comunitário, sendo esta autorização revalidação da autorização ETIG n० 001/00

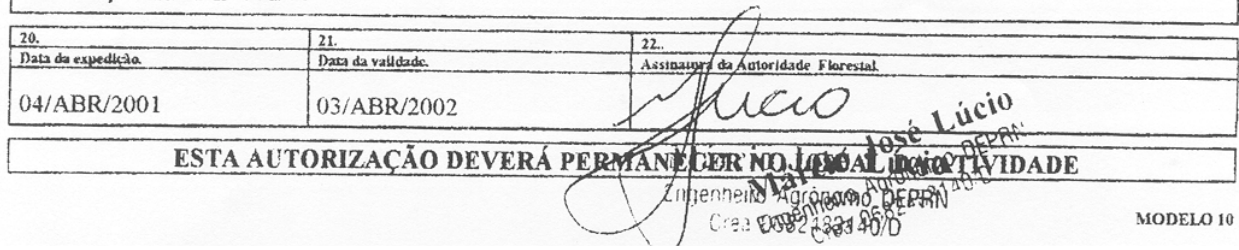




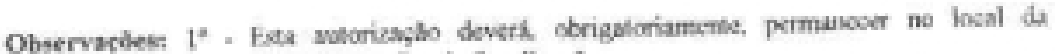
atividade para fins de fiscalicaça

2e. Somente ierá validade apdes publicapalo mo Diário Ofsial do Estailo

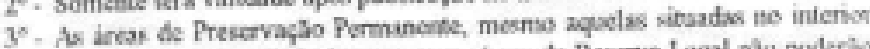
do perimetro ashorizado. ben como as íreas de Reserva Lepal nàn poderâo or coplocidas, a ndo ser se devidsunente auterizada.

Considcrames de Presurvaclo Rermanteste atuelas áreas situadas

4) ao lenpo dos nose co de qualquer curse of dgua desde o seu nivel mais alte an faica murcinal cuja largara minima seja:

1) de 30(trinta) metros prara os cursos d'igua que tenham de manos de loydeci) metros de largurz.

2) \&e 50 (cinquenta) metros para es curses d'água que isuham de 10 (doc) a 50 (cinqienta) metros de largura,

3) de 100 (eem) metrós para os cursos digua qoe tenlam de so(cinqpenta) a 200(duzernos) metros de largora:

4) de 200 (duventax) metros para os cursos d'aggaz qse tenhas de 200 (durzenios) a 600 (sciscentos) metros de largura:

5) de SOO(quinhternos metros para of corsos d'agua que tenham largurn supencr a 600 (seisuentes) metmos,

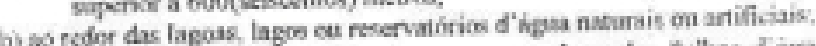

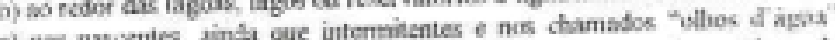

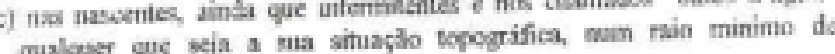
qualquer que seja a gha simuaça

50 (cinqietra) matros de largurs.

d) no topo de nocres, moetes, moctanhas e serras;

e) mas croostas au partes dentas com declividade superior a $49^{\circ}$, opivalents a joirts de linhs de maioe declive:

n nas restiress, come fixadoras de dunss cet estabilizadoras de mangaes

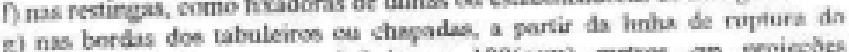
tolevo, em fauxa monca infirior a 100 (cem) metres an projesoles. hacizortais,

b) $\mathrm{em}$ altitade mperior a 1.800 (mil e odocentos) metros qualquer que scjix a vegetn; loc.

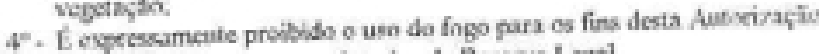

co. E. proibido o corte raso no interior da Reverva Legsil.

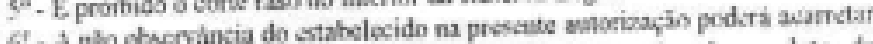

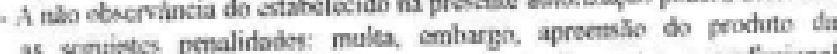

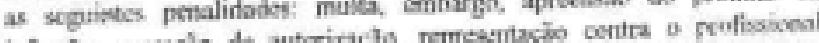

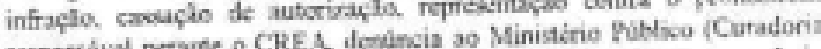

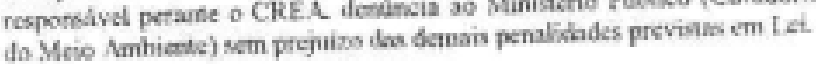




\section{Anexo B - Contrato para estudo técnico do "veludo".}

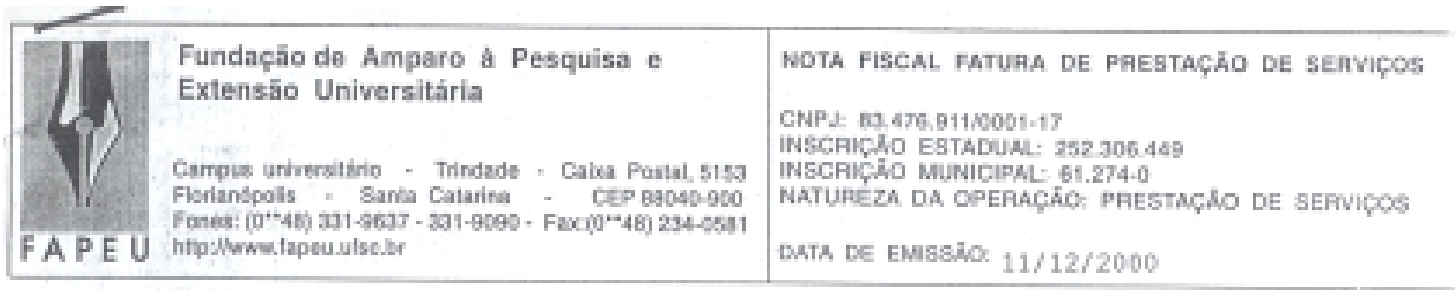

\begin{tabular}{|c|c|c|c|c|c|}
\hline \multirow{3}{*}{ 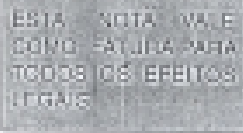 } & \multirow{2}{*}{ 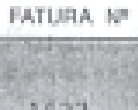 } & \multicolumn{2}{|c|}{ FATURA / DUPLICATA } & \multirow{2}{*}{ VENACINENTO } & \multirow{2}{*}{$\begin{array}{l}\text { MUMEARO DE CONTFOL: } \\
\text { DO FOPMULARIOL }\end{array}$} \\
\hline & & WALOR AS & NP DE DFDEH & & \\
\hline & 4627 & $1.203,33$ & 4627 & & \\
\hline
\end{tabular}

\begin{tabular}{|c|c|c|}
\hline 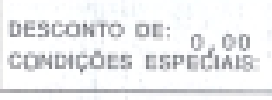 & FARA PAOAMENTO ATE: & $\begin{array}{l}11 \mathrm{VA} \\
\text { DESTINATARIO }\end{array}$ \\
\hline
\end{tabular}

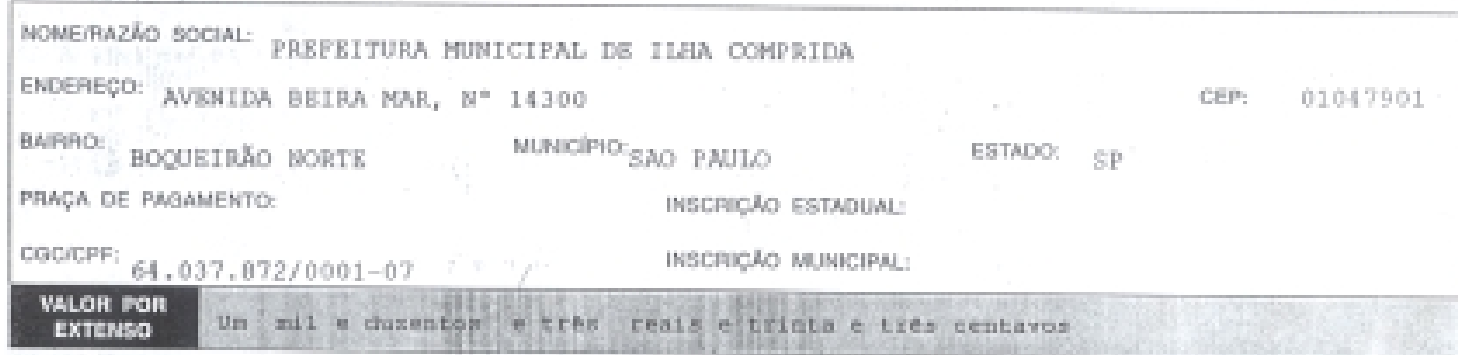

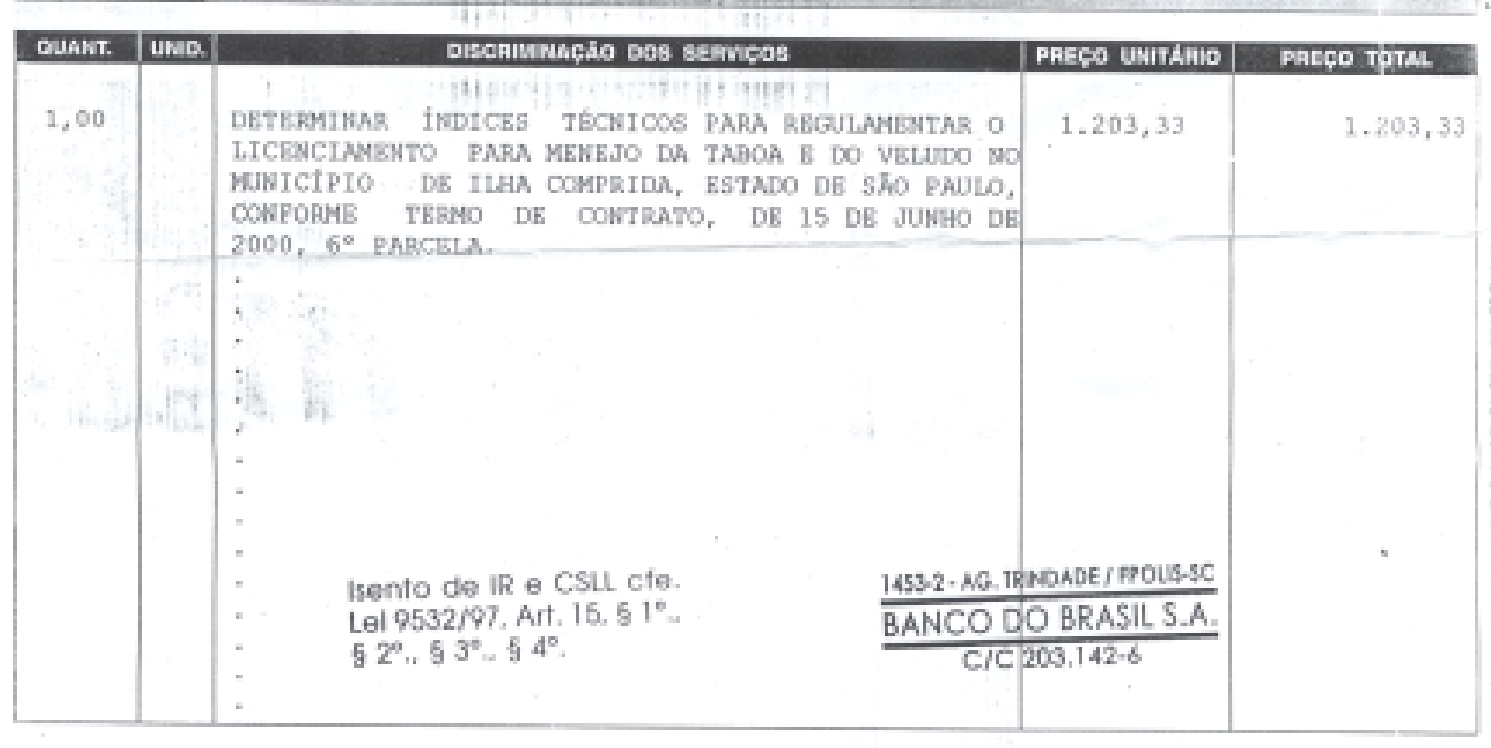
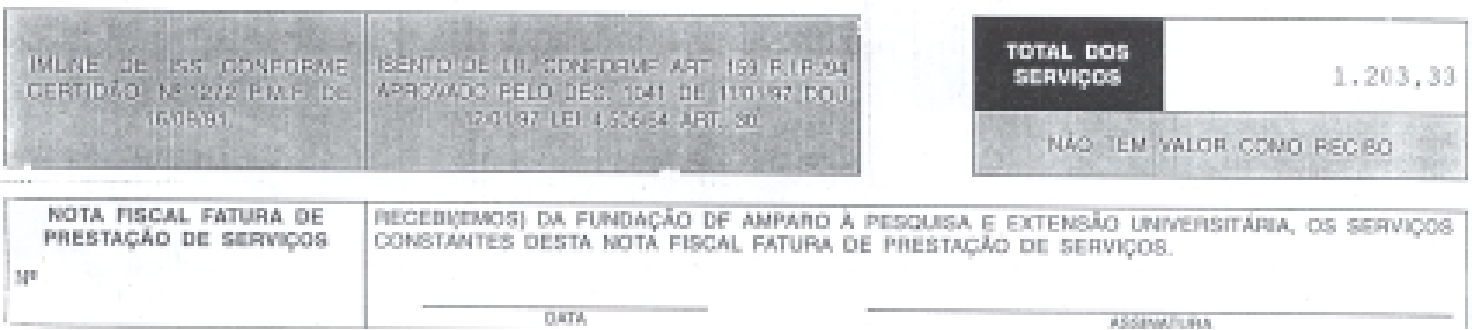


\section{REFERÊNCIAS BIBLIOGRÁFICAS}

ADAMS, C. Caiçaras na Mata Atlântica: pesquisa científica versus planejamento e gestão ambiental. São Paulo: Annablume, FAPESP, 2000. 337p.

ALVES, A. A. Ilha Comprida: uma APA com zoneamento em revisão. São Paulo, 1999. Monografia (Graduação) - Faculdade de Filosofia, Letras e Ciências Humanas, Universidade de São Paulo.

ARRUDA, R. "Populações tradicionais" e a proteção dos recursos naturais em unidades de conservação. Ambiente e Sociedade, v.2, n.5, p.79-107, 1999.

AVANZI, M. R.; COSTA-PINTO, A.; WUNDER, A.; OLIVEIRA, C.; SPEGLICH, E.; NONATO, R.C.; OLIVEIRA, V. G. A trama da rede: reflexões metodológicas sobre construção coletiva de conhecimento e educação ambiental. In: MATA, S. (Org.) Educação Ambiental: projetivas do século. Rio de Janeiro: Mz Editora, 2001.

AVANZI, M. R. Meio ambiente e educação para cidadania: experiências locais nas bacias dos rios Piracicaba e Capivari. São Paulo, 1998. 184p. Dissertação (M.S.) - Faculdade de Educação, Universidade de São Paulo.

BECKER, H. S. Métodos de pesquisa em ciências sociais. 2. ed. São Paulo: Hucitec, 1993. 
BENEVIDES, M. V. A cidadania ativa. São Paulo: Editora Ática,1991.

BENEVIDES, M. V. Cidadania e democracia. Lua Nova, n.33, p.5-16, 1994.

BORDA, O. F. Aspectos teóricos da pesquisa participante: considerações sobre o significado e o papel da ciência na participação popular. In: BRANDÃO, C. R. (Org.). Pesquisa participante. São Paulo: Brasiliense, 1990.

BORRINI-FEYERABEND, G. Manejo participativo de áreas protegidas adaptando o método ao contexto: temas de política social. Quito: UICNSUR, 1997. 68p.

BRITO, M. C. W. Unidades de conservação: intenções e resultados. São Paulo, 1995. 232p. Dissertação (Mestrado) - Programa de Pós-Graduação em Ciência Ambiental, Universidade de São Paulo.

CARVALHO, M. C. P. Histórias da ilha: temporalidade e apropriação do espaço da Ilha Comprida. Campinas, 1999. Dissertação (Mestrado) - Universidade Estadual de Campinas.

CONTE, M. S.; REIS, M. S.; RIBEIRO, R. A. Estudo de parâmetros técnicos para o manejo sustentado da samambaias silvestre (Rumohra adiantiformis ). In: DIEGUES, A. C.; VIANA, V. (Orgs.). Alternativas de manejo sustentável de recursos naturais do Vale do Ribeira/SP - Mata Atlântica. São Paulo, NUPAUB/USP, 2000.

COSTA, L. R. F. "Estratégias de planejamento". Ciência e Cultura, v.38, n.8, p.1366-1373, ago. 1996.

DAYRELL, J. A escola como espaço sócio-cultural. In: DAYRELL, J. (Org.). Múltiplos olhares sobre a educação e cultura. Belo Horizonte: Editora UFMG, 1996. 
DEMO, P. Participação e avaliação: projetos de intervenção e ação. In: SORRENTINO, M. (Org.). Ambientalismo e participação na contemporaneidade. São Paulo: EDUC/FAPESP, 2001. 229p.

DENZIN, N. K. \& LINCOLN, Y. S. Handbook of qualitative research. New York: Sage Publications, 1994.

DIEGUES, A. C. S. 0 mito moderno da natureza intocada: populações tradicionais em unidades de conservação. São Paulo: NUPAUB/USP, 1994. (Série documentos de pesquisa)

DIEGUES, A. C. S. A construção de uma nova ciência da conservação para as áreas protegidas nos trópicos: a etno-conservação. Debates Sócio Ambientais, v.5, n.13, jul./out. 1999.

FERREIRA, L. C. Os ambientalistas, os direitos sociais e o universo da cidadania. In: FERREIRA, L. C.; VIOLA, E. Incertezas de sustentabilidade na globalização. Campinas: UNICAMP, 1996. p.241277.

FREIRE, P. Extensão ou comunicação? Rio de Janeiro: Paz e Terra, 1975.

FURLAN, S. A. Lugar e cidadania: implicações socioambientais das políticas de conservação ambiental (situação do Parque Estadual de Ilhabela na Ilha de São Sebastião, SP). São Paulo, 2000. 383p. Tese (Doutorado) Faculdade de Filosofia, Letras e Ciências Humanas, Universidade de São Paulo.

GADOTTI, M. Perspectivas atuais da educação. Porto Alegre: Artmed, 2000.

GEERTZ, C. A interpretação das culturas. Rio de Janeiro: Guanabara, 1989. 
GONÇALVES, C. W. P. Meio ambiente, ciência e poder: diálogo de diferentes matrizes de racionalidade In: SORRENTINO, M. (Org.). Ambientalismo e participação na contemporaneidade. São Paulo: EDUC/FAPESP, 2001. $229 p$.

GUTIÉRREZ PEREZ, F. Desarrollo sociopolítico y educación comunitaria. In: GADOTTI, M.; TORRES, C. (Orgs.). Educação popular: utopia latinoamericana. São Paulo: Cortez / EDUSP, 1994.

GUTIÉRREZ, F.; PRADO, C. Ecopedagogia e cidadania planetária. São Paulo: Cortez / Instituto Paulo Freire, 1999.

HAGUETTE, T. M. F. Metodologias qualitativas na sociologia. Petrópolis: Editora Vozes, 1987.

HANAZAKI, N. Ecologia de caiçaras: usos de recursos e dieta. 2001. Tese (Doutorado) - Instituto de Biologia, Universidade Estadual de Campinas.

HOGAN, D.; CARMO, R. L.; ALVES, H. R.; RODRIGUES, I. A. Sustentabilidade no Vale do Ribeira (S.P.): conservação ambiental e melhoria das condições de vida da população. Ambiente e Sociedade, v.2, n.3 e 4, p. $151-175,1998$.

JELIN, E. Construir a cidadania: uma visão desde baixo. Lua Nova, n.33, 1994.

LÜDKE, M.; ANDRÉ, M. D. E. A pesquisa em educação: abordagens qualitativas. São Paulo: EPU, 1986.

ORTEGA, F. Para uma política da amizade: Arendt, Derrida, Foulcault. Rio de Janeiro: Relume Dumará, 2000. 
PÁDUA, S. M.; TABANEZ, M. F. Participação comunitária: elemento chave na proteção de unidades de conservação. In: CASCINO, F.; JACOBI, P.; OLIVEIRA, J. F. (Org.). Educação, meio ambiente e cidadania: reflexões e experiências. São Paulo: SMA/CEAM, 1998.

PREFEITURA MUNICIPAL DE ILHA COMPRIDA. Secretaria de Ecologia e Pesca. Caracterização da Ilha. Ilha Comprida,1995.

PREFEITURA MUNICIPAL DE ILHA COMPRIDA. Secretaria de Ecologia e Pesca. APA de Ilha Comprida: proposta de ação. Ilha Comprida, 1997.

PREFEITURA MUNICIPAL DE ILHA COMPRIDA. Secretaria de Saúde. Plano municipal de saúde, 1997.

RODRIGUES, C. L. Limites do consenso: territórios polissêmicos na Mata Atlântica e a gestão ambiental participativa. São Paulo, 2001. 197p. Tese (Doutorado) - Faculdade de Filosofia, Letras e Ciências Humanas, Universidade de São Paulo.

SANTOS, B. S. Para uma pedagogia do conflito. In: SILVA, L. H. (Org.). Novos mapas culturais: novas perspectivas educacionais. Porto Alegre: Editora Sulina, 1996.

SANTOS, B. S. Pela mão de Alice: o social e o político na pós-modernidade. São Paulo: Cortez, 1999.

SÃO PAULO (Estado). Secretaria Estadual do Meio Ambiente. Departamento Estadual de Proteção dos Recursos Hídricos / Secretaria de Educação. Programas de Educação Ambiental do Vale do Ribeira: as formações vegetais do Vale do Ribeira. São Paulo, 1989. 
SÃO PAULO (Estado). Secretaria Estadual do Meio Ambiente. Regulamentação da APA Cananéia-Iguape-Peruíbe: plano de gestão / unidade de gestão / ZEE preliminar. São Paulo, 1996. 64p.

SÃO PAULO (Estado). Secretaria do Estado do Meio Ambiente/Coordenadoria de Planejamento Ambiental. Programa de gerenciamento costeiro. São Paulo, 1989.

SÃO PAULO (Estado). Secretaria do Estado do Meio Ambiente. Plano de ação para o controle das inundações e diretrizes para o desenvolvimento do Vale do Ribeira. São Paulo, 1998.

SAWAIA, B. B. Participação social e subjetividade. In: SORRENTINO, M. (Org.). Ambientalismo e participação na contemporaneidade. São Paulo: EDUC/FAPESP, 2001. 229p.

SAWAIA, B. B. "Uma contribuição ao debate sobre a pesquisa ação participante": a consciência em construção no trabalho de construção da existência. São Paulo, 1987. Tese (Doutorado) - Pontifícia Universidade Católica de São Paulo.

SOARES, A.; MATSUMOTO, M.; OLIVEIRA, V.G. et al. Uso e ocupação do solo em APA: o caso de Ilha Comprida. In: DIEGUES, A. C.; VIANA, V. (Orgs.). Alternativas de manejo sustentável de recursos naturais do Vale do Ribeira/SP - Mata Atlântica. São Paulo: NUPAUB/USP, 2000.

SORRENTINO, M. Crise ambiental e educação. In: QUINTAS, J. S. (Org.). Pensando e praticando a educação ambiental na gestão do meio ambiente. Brasília: Editora IBAMA, 2000. p.94-104.

SORRENTINO, M. Educação ambiental e universidade. In: BARBOSA, S. R. S. (Org.). A temática ambiental e a pluralidade no ciclo de seminários do NEPAM. Campinas: UNICAMP, 1998. (Textos NEPAM, Série Divulgação Acadêmica, 4) 
SORRENTINO, M. Educação ambiental e universidade: um estudo de caso. São Paulo, 1995. 263p. Tese (Doutorado) - Faculdade de Educação, Universidade de São Paulo.

TASSARA, E. T. O. Globalização, paradigmas e utopias: questões de método na pesquisa social contemporânea. Coletâneas ANPEPP, v.1, n.13, p.8395, set. 1996.

TELLES, V. Sociedade civil e a construção de espaços públicos. In: DAGNINO, E. (Org.). Anos 90: política e sociedade do Brasil. São Paulo: Editora Brasiliense, 1994.

THIOLLENT, M. Metodologia da pesquisa-ação. São Paulo: Cortez, 1986.

TOURAINE, A. Crítica da modernidade. 4.ed. Petrópolis: Vozes, 1997.

TRIVIÑOS, A. N. S. Introdução à pesquisa em ciências sociais: a pesquisa qualitativa em educação: o positivismo, a fenomenologia, o marxismo. São Paulo: Atlas, 1990.

VIEZZER, M.; OVALLES, O. (Orgs.). Manual latino-americano de Educação Ambiental. São Paulo: Gaia, 1995. 